\title{
Invasion and angiogenesis in endometriosis : experimental studies in the chick embryo chorioallantoic membrane
}

Citation for published version (APA):

Maas, J. W. M. (2001). Invasion and angiogenesis in endometriosis : experimental studies in the chick embryo chorioallantoic membrane. [Doctoral Thesis, Maastricht University]. Universiteit Maastricht. https://doi.org/10.26481/dis.20010622jm

Document status and date:

Published: 01/01/2001

DOI:

10.26481/dis.20010622jm

Document Version:

Publisher's PDF, also known as Version of record

Please check the document version of this publication:

- A submitted manuscript is the version of the article upon submission and before peer-review. There can be important differences between the submitted version and the official published version of record.

People interested in the research are advised to contact the author for the final version of the publication, or visit the DOI to the publisher's website.

- The final author version and the galley proof are versions of the publication after peer review.

- The final published version features the final layout of the paper including the volume, issue and page numbers.

Link to publication

\footnotetext{
General rights rights.

- You may freely distribute the URL identifying the publication in the public portal. please follow below link for the End User Agreement:

www.umlib.nl/taverne-license

Take down policy

If you believe that this document breaches copyright please contact us at:

repository@maastrichtuniversity.nl

providing details and we will investigate your claim.
}

Copyright and moral rights for the publications made accessible in the public portal are retained by the authors and/or other copyright owners and it is a condition of accessing publications that users recognise and abide by the legal requirements associated with these

- Users may download and print one copy of any publication from the public portal for the purpose of private study or research.

- You may not further distribute the material or use it for any profit-making activity or commercial gain

If the publication is distributed under the terms of Article $25 \mathrm{fa}$ of the Dutch Copyright Act, indicated by the "Taverne" license above, 
Curriculum vitaie Jacques Maas werd op 21 juni 1970 te Breda geboren. Op 2 oktober 1995 studeerde hij af aan de Faculteit der Geneeskunde van de Universiteit Maastricht. Vervolgens. werkte hij tot en met oktober 2000 als IVF-arts in het academisch ziekenhuis Maastricht. Tevens heeft hij van september 1995 tot en met december 1996 de basiscursus seksuologie gevolgd, een gemeenschappelijke activiteit van de Nederlandse Vereniging voor Seksuologie en de Commissie Postacademisch Onderwijs Geneeskunde van de Erasmus Universiteit Rotterdam. In januari 1997 werd, naast het klinisch werk op de IVF-afdeling, gestart met het onderzoek beschreven in dit proefschrift. Het onderzock werd uitgevoerd binnen het onderzoeksinstituut Groei en Ontwikkeling (GROW) van de Universiteit van Maastricht, afdeling Obstetrie en Gynaecologie ibegeleider: Prof, dr. J.L.H. Evers) in samenwerking met CARIM (Cardiovascular Research Institute Maastricht), afdeling Farmacologie (begeleider: Prof: dr. H.A.J. Struijker Boudier). 
Invasion and angiogenesis in endometriosis

Experimental studies in the chick embryo chorioallantoic membrane 
() Jacques W.M. Maas, Maastricht, 2001

ISBN 90-90 14767-5

Design Beeld acht, Maastricht

Printing Datawyse, Maastricht 


\section{Invasion and angiogenesis in endometriosis}

Experimental studies in the chick embryo chorioallantoic membrane
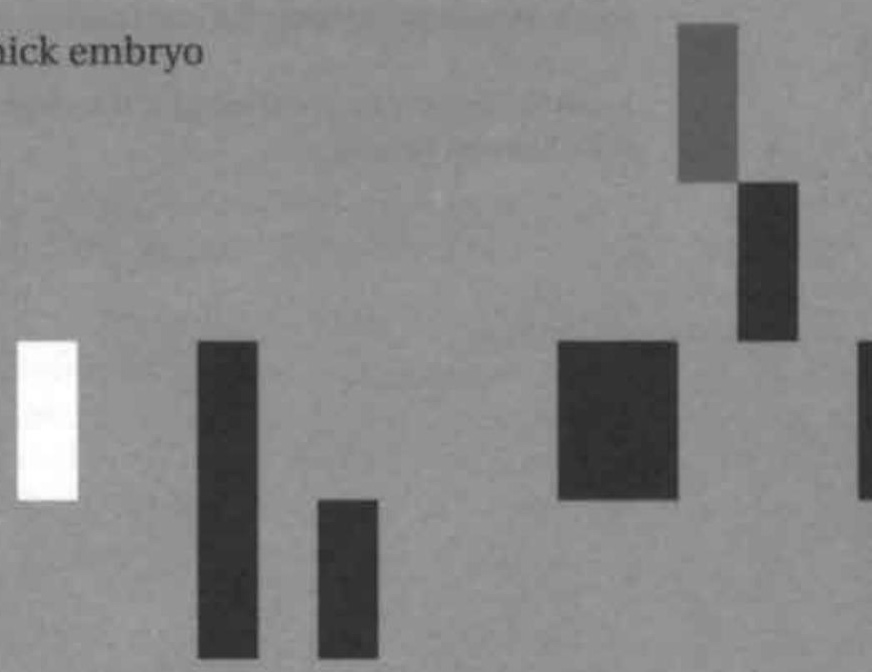

\section{Troefschrift}

ter verkrijging van de graad van doctor

aan de Universiteit Maastricht, op gezag van de

Rector Magnificus, Prof. dr. A.C. Nieuwenhuijzen Kruseman; volgens het besluit van het College van Decanen, in het openbaar te verdedigen op vrijdag 22 juni 2001 om 14.00 uur

door

Jacques W.M. Maas 


\section{Promotores}

Prof.dr. J.L.H. Evers

Prof.dr. H.A.J. Struijker Boudier

\section{Co-promotores}

Dr. G.A.J. Dunselman

Dr. A.F.PM. de Goeij

\section{Beoordelingscommissie}

Prof. dr. J. Wagstaff (voorzitter)

Prof. dr. M.J.A.P. Daemen

Prof. dr. J Donnez (Universitaire Kliniek, St Luc, Brussel, België)

Prof. dr. M.J.H.M. Jacobs

Prof. A. Starzinski-Powitz, PhD (Goethe Universität, Frankfurt, Duitsland)

The studies presented in this thesis were supported by an unrestricted grant from the Searle-Monsanto Company b.v. and Stipendium Oranjekliniek

Financial support for the printing of this thesis has kindly been provided by N.V. Organon, Fertility 


\section{Voortreffelijke boeken}

Voortreffelijke boeken kocht ik.

Zij willen graag mijn koop belonen.

Maar ongelezen wachten zij,

Want steeds verwijlt mijn geest het meest

Bij jullie-schonen.

Jan Hanlo 


\section{Dankwoord}

De grootste vrees bij het schrijven van een dankwoord is dat je iemand vergeet. Derhalve wil ik in de eerste plaats eenieder die me geholpen heeft bij het tot stand brengen van dit proefschrift van harte bedanken en me verontschuldigen voor het feit dat het niet mijn karakter is mijn dankbaarheid telkens te verwoorden. Ik wil toch van deze unieke gelegenheid gebruikmaken een aantal mensen persoonlijk te bedanken.

Beste Hans, het is nu precies 10 jaar geleden dat ik voor een wetenschapsstage bij je aanklopte. Mijn promotie is een mooi resultaat van deze samenwerkingsperiode. Bedankt voor de gelegenheid die je me geboden hebt ervaring op te doen, zowel in de kliniek op het gebied van fertiliteit, als in onderzoek.

Prof. dr. H.A.J. Struijker Boudier. Ik heb nooit de vrijheid genomen $\mathrm{u}$ met de voornaam aan te spreken, hoewel de sfeer op uw afdeling er zeker wel naar is. Zonder de faciliteiten, zowel materieel als personeel, die u mij geboden heeft, zou dit onderzoek nooit verricht zijn. Beste Harry, bedankt voor het in mij gestelde vertrouwen.

Beste Gerard, als een van de weinige gynaecologen in Nederland houd je je bezig met onderzoek naar het ontstaan van de 'gevreesde ziekte' endometriose. Je hebt ervoor gezorgd, dat een aantal mensen zich vol enthousiasme inzet voor dit onderzoek dat binnen de endometriosewereld zeer gewaardeerd en vaak geciteerd wordt. Bedankt dat ik hieraan mijn bijdrage heb mogen leveren.

Beste Ton, ondanks je vele andere werkzaamheden heb je toch altijd de tijd genomen om alle manuscripten en dit proefschrift zeer nauwkeurig en kritisch door te lezen en te corrigeren. Jouw vraag "wat wil je nu precies zeggen", je kennis van onderzoek en de Engelse taal hebben bijgedragen aan een significante verbetering van dit werk. Bedankt voor je menselijke benadering in de vaak afstandelijke academische omgeving.

Patrick, pas veel te laat heb ik gebruikgemaakt van je kennis en ideeën. Bedankt voor de discussies, gedachtewisselingen, tips en je altijd luisterend oor. Jouw rust, relativering en gedrevenheid waren een belangrijke bron van mijn motivatie.

Lilian, toeval bestaat niet. Op het moment dat ik bij jou het lab binnen liep, was net het onderzoek van Ferdi afgerond en waren er nog geen vaste plannen voor vervolg. onderzoek. Vol enthousiasme stortte je je in dit endometrioseonderzoek. Mijn dank voor jou is groot. Ik hoop van harte dat je bij mijn promotie aanwezig kunt zijn, hoewel de reden van je mogelijke afwezigheid voor jou geen mooiere kan zijn. Veel geluk toegewenst.

De vakgroep farmacologie, met name onderzoekers en analisten, wil ik bedanken voor de hulp en gastvrijheid. Ferdi, bedankt voor je introductie in het CAM-onder- 
zoek en Helma, bedankt dat ik gebruik mocht maken van je enorme laboratoriumervaring. Geen enkele vraag leek te veel.

Alle overige leden van de endometrium-endometriose groep, bedankt voor de leerzame, inspirerende en ook gezellige vrijdagmiddagbesprekingen. Jullie oprechte interesse, plezier in onderzoek en bereidheid altijd te helpen, waardeer ik enorm. Ayse, bedankt voor het benaderen van proefpersonen, je hulp bij het isoleren van menstrueel endometrium en je vriendelijkheid. Heel veel succes met je onderzoek. Helen en Hanny, ik heb bewondering voor jullie doorzettingsvermogen. Het was fijn ervaringen in kliniek en onderzoek met jullie te delen, veel succes met het afronden van opleiding en promotieonderzoek.

IVF-team, vanuit de schoolbanken kwam ik bij jullie terecht. Ik heb veel van jullie geleerd en prettig met jullie samengewerkt, waarvoor mijn dank. De tijdsdruk die ik eigenlijk al vanaf dag een voelde, zorgde ervoor dat ik me niet altijd flexibel heb opgesteld en te weinig tijd heb genomen om tijdens het werk gezelligheid op te zoeken. Ik dacht dat elke minuut 'te veel' op de IVF ten koste zou gaan van mijn onderzoek en het moment dat ik in opleiding zou komen. Pas later heb ik ervaren dat andere factoren dat bepalen. Germaine, te weinig waardering is er geweest voor jouw volledige inzet en voor het verpleegkundig werk in het algemeen op deze afdeling. Ik bedank je voor de fijne samenwerking. Tanja, het was mijn geluk jou als collega te hebben. Zonder jouw flexibiliteit had ik dit proefschrift nooit binnen deze termijn afgerond. Heel veel succes en behoud je oorspronkelijke motivatie.

Alle assistenten gynaecologie wil ik bedanken voor het afnemen van de pipelle biopten. Meer nog wil ik jullie allen bedanken voor jullie steun en begrip. Ik hoop dat ik jullie in de toekomst nog regelmatig tegenkom.

Edwin, je bezit het talent de essentie van complexiteit vorm te geven in unieke, stijlvolle eenvoud. Bedankt dat ik daarvan gebruik mocht maken.

Jaap, onze vriendschap houdt al bijna 25 jaar stand, ik vind het bijzonder dat je me ook bij de promotie wilt bijstaan. Esther, dat je mijn paranimf bent lijkt vanzelfsprekend, maar het is zeer speciaal een vriendin te hebben die je op de belangrijkste momenten altijd weer ter zijde staat.

Pap en Mam, jullie hebben me altijd gesteund in elke keuze die ik maakte.

Bedankt voor jullie onvoorwaardelijke liefde en vertrouwen.

Mam, even stevig vasthouden en nog een keer mogen zien hoe trots je op me bent...

Wetenschap is het onophoudelijk zoeken naar zeker weten. Gelukkig heb ik mijn eigen zekerheid gevonden. Gilles, je bent mijn rust en vertrouwen.

Wir werden durch Not und Freude gehen, Hand in Hand, bis tief im Abendrot. 


\section{Chapter 1}

General introduction

Endometriosis and its pathogenesis

Invasion

Angiogenesis

The chick embryo chorioallantoic membrane (CAM)

\section{Chapter 2}

Aims of the study

\section{Chapter 3}

Invasive potential of human endometrial cells in the chick embryo chorioallantoic membrane model

\section{Chapter 4}

Development of endometriosis-like lesions after transplantation of human endometrial fragments onto the chick embryo chorioallantoic membrane

\section{Chapter 5}

The chick embryo chorioallantoic membrane as a model to investigate the angiogenic properties of human endometrium

\section{Chapter 6}

Endometrial angiogenesis throughout the human menstrual cycle

\section{Chapter 7}

Tumor necrosis factor- $\alpha$ but not interleukin- $1 \beta$ or interleukin- 8 concentrations correlate with angiogenic activity of peritoneal fluid from patients with minimal to mild endometriosis

\section{Chapter 8}

General discussion

\section{Summary}





\begin{tabular}{|c|c|}
\hline $\mathrm{AE}$ & allantoic endoderm \\
\hline $\mathrm{aFGF}$ & acidic fibroblast growth factor \\
\hline ANG & angiotensin \\
\hline bFGF & basic fibroblast growth factor \\
\hline CAM & chorioallantoic membrane \\
\hline CCD & charge-coupled device (camera) \\
\hline CE & chorionic ectoderm \\
\hline DAPI & 4-,6-diaminodino-2-phenylindole \\
\hline DMEM & Dulbecco's modified Eagle's medium \\
\hline ECC & endometrium carcinoma cell \\
\hline ECM & extracellular matrix \\
\hline FGF & fibroblast growth factor \\
\hline FISH & fluoresence in situ hybridization \\
\hline HE & hematoxylin and eosin \\
\hline HUVEC & human umbilical vein endothelial cell \\
\hline IL & interleukin \\
\hline Ig & immunoglobulin \\
\hline ISH & in situ hybridization \\
\hline MMP & matrix metalloproteinase \\
\hline PA & plasminogen activator \\
\hline PAI & plasminogen activator inhibitor \\
\hline PBS & phosphate buffered saline \\
\hline IASRM & revised American Society for Reproductive Medicine \\
\hline SD & standard deviation \\
\hline SSC & saline sodium citrate \\
\hline SPSS & statistical product and service solutions \\
\hline TGF & transforming growth factor \\
\hline TIMP & tissue inhibitors of metalloproteinase \\
\hline TNF & tumor necrosis factor \\
\hline TRITC & tetramethylrhodamin isothiocyanate \\
\hline TSP & thrombospondin \\
\hline VDI & vascular density index \\
\hline VEGF & vascular endothelial growth factor \\
\hline
\end{tabular}




\section{Chapter 1}

General introduction

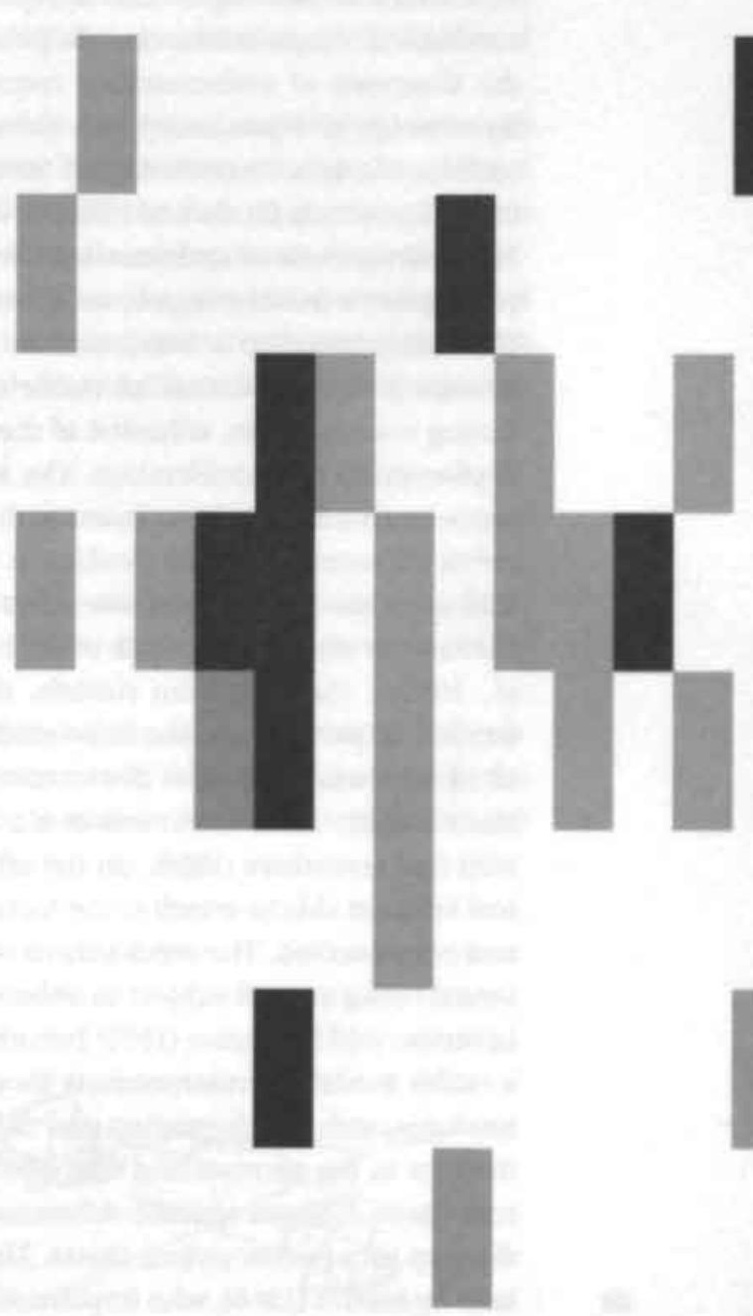




\section{3ndometriosis and its pathogenesis}

Endometriosis is the presence of tissue with epithelial and stromal characteristics of endometrium outside the uterine cavity. Endometriosis commonly affects the pelvic peritoneum close to the ovaries, including the uterosacral ligaments, the ovarian fossa peritoneum, and the peritoneum of the cul-de-sac (Janssen and Russel, 1986; Jenkins et al., 1986). The ectopic endometrial tissue responds to ovarian steroids similar to eutopic endometrium: endometriosis is linked to the reproductive years, responds to hormonal therapy and its productive activity resumes if, after the end of pharmaceutical suppression, ovarian activity resumes and the lesions are stimulated again by ovarian steroids.

The characteristic signs and symptoms associated with endometriosis are dysmenorrhea, dyspareunia, chronic pelvic pain and impaired fertility. Confirmation of the diagnosis of endometriosis requires visualization of endometriotic lesions at laparoscopy or laparotomy with subsequent histological examination. Accordingly, endometriosis is diagnosed in $45-50 \%$ of patients with chronic pelvic pain as well as in asymptomatic fertile and infertile women (Balasch et al., 1996).

The pathogenesis of endometriosis is still poorly understood. Several theories on its pathogenesis have been proposed, but as yet, two main concepts can be discerned. The transplantation or implantation theory described by Sampson (1927) presumes retrograde transportation of viable endometrial cells through the fallopian tubes during menstruation, adhesion of these cells onto the peritoneum, with subsequent implantation and proliferation. The anatomic distribution of endometriotic lesions supports this theory. Sites closest to the tubal fimbriae and dependent portions of the pelvis are usually affected (Jenkins et al., 1986). Also, the presence of viable endometrial cells has been demonstrated in peritoneal fluid of women with patent tubes (Badawy et al., 1984; Bartosik et al., 1986; Kruitwagen et al., 1991; van der Linden et al., 1995a). Using in vitro models, the adhesion of endometrial tissue to human amnion or peritoneum has been studied. The results strongly suggest that adhesion of endometrial fragments does not occur when the mesothelium is intact (Van der Linden et al., 1996; Groothuis et al., 1998; Groothuis et al., 1999; Koks et al., 1999). Witz and coworkers (1999), on the other hand, demonstrated that endometrial stromal cells are able to attach to the intact mesothelium, but adhesion of epithelial cells was not observed. The mechanisms of adhesion of the endometrial cells to the peritoneal lining are still subject to debate.

Levander and Normann (1955) introduced the induction theory for endometriosis. In a rabbit model of endometriosis they observed degeneration of rabbit endometrial implants, with cyst formation and differentiation characteristics of endometrial epithelium in the surrounding connective tissue. They concluded that dying endometrial tissue releases specific substances activating undifferentiated mesenchyme to develop into endometrium tissue. These experiments were confirmed several years later by Merrill (1966), who implanted millipore filters containing fragments of endometrium subperitoneally in the rabbit. Endometrium-like epithelial glands and stroma were observed in the connective tissue adjacent to the implants. Recently, Ohtake and coworkers (1999) concluded that endometriotic lesions indeed are able to arise 
through a process of metaplasia from ovarian surface epithelial cells in the presence of endometrial stromal cells and estradiol.

At present, the implantation theory is widely accepted, although metaplasia may constitute an additional explanation. In both theories retrograde menstruation and adhesion of shed endometrial cells to the peritoneal lining are essential elements. However, retrograde menstruation occurs in most, if not all, women with patent tubes and is much more prevalent than endometriosis, suggesting that in itself it is not sufficient to cause the disease. The sheer volume and/or the tissue properties of regurgitated menstrual debris have been suggested to determine whether endometriosis will develop or not (Evers et al., 1998). On the other hand, various recent studies have suggested a crucial role of the peritoneal environment in the establishment and maintenance of endometriosis (Oral et al., 1996; Koninckx et al., 1998; Küpker et al., 1998).

It is still not clear what occurs between retrograde seeding of endometrial cells and the clinical recognition of endometriotic lesions. Implantation requires, in addition to adhesion, also invasion of endometrial cells and from that stage onwards these cells will depend on the formation of new blood vessels, angiogenesis, for further outgrowth and development into an endometriotic lesion. The critical tissue volume that should be reached before clinical recognition of the implant constitutes at the same time the volume beyond which further growth is impossible without neovascularization.

\section{Invasion}

Three steps can be distinguished in the complex process of invasion (Figure 1): attachment, degradation, and migration (reviewed by Stetler-Stevenson et al., 1993a; 1993 b and Curran and Murray 1999; 2000).

Several specific cell surface-associated molecules that modulate cell-matrix and cellcell attachment have been identified and characterized (Table 1). These include the integrins, the cadherins, the laminin-binding protein, the immunoglobulin (Ig)

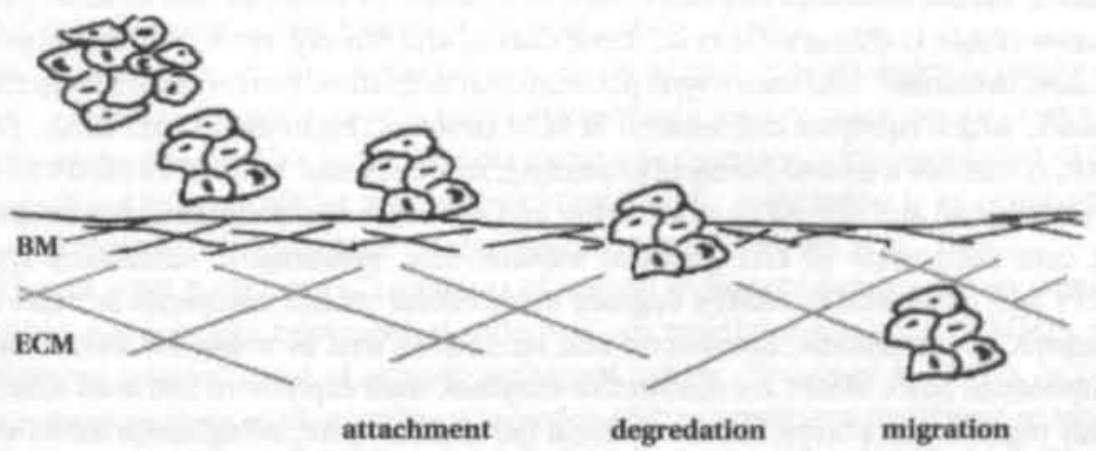

Figure 1 Invasion. Following detachment from their point of origin, cells attach to and degrade the basement membrane (BM) and extracellular matrix (ECM). Subsequently, the cells migrate through the ECM by continuous steps of attachment and degradation. 
superfamily, and CD 44 (Stetler-Stevenson et al., 1993a). The integrins are a large family of cell adhesion receptors, consisting of an $\alpha$ and a $\beta$ subunit. To date, $24 \alpha \beta$ heterodimers formed by 8 different $\beta$ and $18 \alpha$ subunits are known. Eighteen types of integrins recognize and bind to matrix proteins while others have cell surface proteins as their counter-receptors (Ivaska and Heino, 2000). The integrins provide anchorage for cells to the ECM and are involved in directed invasion and motility of cells (Curran and Murray, 2000), Cadherins mediate cell-cell binding, inhibiting the ability of cells to escape from their primary site to initiate invasion. Therefore, cadherins can act as invasion suppressor molecules (Stetler-Stevenson et al., 1993b).

\begin{tabular}{|c|c|c|}
\hline \multirow[t]{2}{*}{ Adhesion } & \multicolumn{2}{|l|}{ Proteolysis } \\
\hline & stimulators & inhibitors \\
\hline Integrins & $\begin{array}{l}\text { Serine proteiriases } \\
\text { urokinase-type plasminogen activator }\end{array}$ & $\begin{array}{l}\text { Serine proteinases inhibitors } \\
\text { plasminogen activator injibitor }\end{array}$ \\
\hline Cadherins & tissue-type plasminogen activator & $\alpha$-2-antiplasmin \\
\hline \multicolumn{3}{|l|}{ E-cadherin } \\
\hline N-cadherin & Metalloproteinases (MMPs) & Metalloproteinases inhibitors \\
\hline P.cadherin & $\begin{array}{l}\text { collagenases } \\
\text { stromelysins }\end{array}$ & tissue inhibitors of MMP \\
\hline Laminin-binding protein & $\begin{array}{l}\text { gelatinases } \\
\text { membrane-type MMP }\end{array}$ & $\begin{array}{l}\text { general protease inhibitors } \\
\alpha-1 \text { antitrypsin }\end{array}$ \\
\hline Ig superfamily & other MMPs & a-2 macroglobulin \\
\hline \multicolumn{3}{|l|}{$N-C A M$} \\
\hline VCAMI & $\begin{array}{l}\text { Cysteine proteinases } \\
\text { cathepsins B and } L\end{array}$ & \\
\hline \multicolumn{3}{|l|}{ CD 44} \\
\hline & $\begin{array}{l}\text { Aspartic proteinases } \\
\text { cathepsin D }\end{array}$ & \\
\hline
\end{tabular}

The degradation of extracellular matrix (ECM) proteins can be affected by serine proteinases, matrix metalloproteinases (MMPs), cysteine proteinases and aspartic proteinases (Table 1) (Ellenrieder et al., 1999; Curran and Murray, 1999). The serine proteinases, urokinase- and tissue-type plasminogen activators, convert plasminogen to plasmin, which catalyzes degradation of ECM proteins (Andreasen et al., 2000). The MMPs constitute a related family of proteolytic zinc enzymes. To date, 19 MMPs have been identified and according to structure and substrate specificity they can be divided into subgroups of collagenases, stromelysins, gelatinases, membrane-type MMPs and other MMPs. MMPs degrade extracellular matrix components, such as collagens, proteoglycans, fibronectin and laminin as well as basement membrane components. Since MMPs are destructive enzymes, their expression and activation is highly regulated in normal tissues via local tissue factors, including tissue inhibitors of MMPs (TIMPs), plasminogen activator inhibitor (PAI-1) and general protease inhibitors such as $\alpha-2$ macroglobulin and $\alpha-1$ antitrypsin. MMP expression is regulated 
by multiple extracellular factors, including cytokines, growth factors, and interactions with adjacent cells and ECM (Hulboy et al., 1997; Osteen et al., 1999; Westermarck and Kăhäri, 1999; Curran and Murray, 1999; 2000; Johansson et al., 2000).

Cell migration involves attachment of the leading edge, cell contraction, and detachment of the trailing edge. Complex, coordinated interactions between proteinases and adhesion molecules take place in order to facilitate migration of cells through the ECM (Friedl and Bröcker, 2000).

\section{Invasive potential of endometrial cells}

The human endometrium is an unique adult tissue that undergoes growth, differentiation, tissue breakdown and repair during a single menstrual cycle. Integrins are expressed in endometrium and some show cyclic variation (Van der Linden et al., 1994; 1995b). The precise pattern, however, has to be elucidated (Starzinsky-Powitz et al., 1999). Expression of E-cadherin has been demonstrated in endometrial epithelial gland cells and does not vary throughout the menstrual cycle (Van der Linden et al., 1994; 1995b; Gaetje et al., 1997).

The MMP expression in endometrium is upregulated locally by cytokines and growth factors, e.g., TNF- $\alpha$, IL-1 $\alpha$, IL-6, insulin-like growth factor-II, epidermal growth factor and platelet derived growth factor (Singer et al. 1999; Osteen et al., 1999). Systemically, MMP expression in endometrium is influenced by hormones: estradiol, relaxin and serotonin induce, whereas progesterone and glucocorticoids inhibit the MMP expression (Hulboy et al., 1997; Osteen et al., 1999). During menstruation, when the vast majority of tissue breakdown occurs, several MMPs are highly expressed. In general, MMP concentrations decline to low or undetectable values during the remainder of the menstrual cycle (Hulboy et al., 1997).

In endometriosis, the cellular mechanisms required for establishment of ectopic endometrial growth represent invasive events and involve extensive degradation of the extracellular matrix. In antegradely shed menstrual endometrium various integrins, MMPs and TIMPs are expressed. It was suggested that these menstrual cells, after having been shed retrogradely and after adherence to the submesothelial layer, use their own MMP activity to invade the extracellular matrix, resulting in the development of endometriotic lesions (Koks et al., 2000a; 2000b).

The concentration of aminoterminal propeptide of type III procollagen in peritoneal fluid is increased in patients with early endometriotic lesions as compared to women without the disease. This increased concentration originates from degradation of collagen fibers in extracellular matrix, indicating that the early lesion is an active stage of endometriosis, invading the extracellular matrix (Spuijbroek et al., 1992).

Using athymic nude mice as recipients of human endometrial tissue, it was demonstrated that estrogen treatment of endometrium maintains secretion of MMPs and promotes establishment of ectopic peritoneal lesions (Bruner et al., 1997). In contrast, suppressing metalloproteinase secretion with progesterone treatment, or blocking enzyme activity with TIMP-1, inhibited the formation of ectopic lesions (Bruner et al., 1997). These observations suggest an active role of MMPs in the development 
of ectopic endometriotic lesions. Moreover, in women with endometriosis the TIMPI concentrations were significantly lower in peritoneal fluid and sera compared with disease-free women (Sharpe-Timms et al., 1998). Apparently, a disbalance in the concentrations of MMPs and TIMPs, in favour of MMPs, is needed for the endometrial cells to invade the extracellular matrix and to develop into an endometriotic lesion. At the cellular level, Gaetje and coworkers (1995) provided evidence that cells from peritoneal endometriotic lesions express an invasive phenotype in an in vitro collagen gel invasion assay. In a follow-up study these in vitro invasive endometriotic cells were found to be epithelial cells lacking E-cadherin. E-cadherin acts as an invasion suppressor molecule in carcinomas, probably by keeping the epithelial cells attached to each other in their primary tissue. In contrast to endometriotic cells, the few eutopic endometrial cells that were invasive in vitro did not express E-cadherin or cytokeratin, indicating that these cells were either endometrial stromal cells or fibroblasts (Gaetje et al. 1997). The results of these studies are in line with the idea that endometriosis cells and carcinoma cells share molecular mechanisms of invasion and metastasis that are related to the absence of E-cadherin. In metastasizing carcinoma cells, either the E-cadherin gene or genes of associated proteins are often mutated. However, this has not been found in endometriotic tissue so far (Starzinsky-Powitz et al. 1999). The deregulation of the E-cadherin system could also be under influence of the peritoneal environment. In fact, the invasive capacity of endometriotic cells, but not eutopic endometrial cells, was considerably enhanced by addition of peritoneal fluid to the culture medium. These findings suggest that also the peritoneal fluid might contribute to the invasive step in the pathogenesis of endometriosis (Starzinski-Powitz et al., 1998).

\section{- Angiogenesis}

The vascular system conveys to every tissue the blood components that are required for cell life. In humans more than 50 kilometres of vessels are lined by a monolayer of endothelial cells, the endothelial surface area covering more than 1000 square metres. Ninety per cent of this surface concerns the microcirculation. Under normal conditions endothelial cells seldomly divide, and their turnover is very low, measured in years (Le Querrec et al., 1993). In an adult vessel presumably only $0.01 \%$ of the cells participate actively in the cell division cycle (Hanahan and Folkman, 1996). Quiescent endothelial cells can be stimulated to divide rapidly in conditions when new vessels must be formed. During embryogenesis angioblasts differentiate from mesoderm in situ and assemble into capillaries; this process is termed vasculogenesis. Later, new capillary blood vessels predominantly arise from pre-existing vessels in a process called angiogenesis, although vasculogenesis may also occur (Le Querrec et al., 1993; Carmeliet, 2000). There are at least two different types of angiogenesis: sprouting of capillaries from pre-existing vessels, and non-sprouting angiogenesis (Folkman, 1985; Risau, 1997; Jain et al., 1997; Carmeliet, 2000; Griffioen and Molema, 2000).

Sprouting angiogenesis develops through a series of sequential steps (Figure 2): (1) an 
angiogenic stimulus arises from a particular tissue; (2) vasodilation and increase in vascular permeability: (3) local degradation of the basement membrane at the side of a small venule closest to the angiogenic stimulus resulting from the action of collagenase and plasminogen activator secreted by the endothelial cells; (4) migration of endothelial cells towards the angiogenic stimulus; (5) proliferation of endothelial cells in the midsection of the sprout; (6) lumen formation in the endothelial sprout; (7) formation of branches and loops by confluence/anastomoses of sprouts to permit blood flow; (8) investment of the vessel with pericytes; and (9) formation of basement membrane around the immature vessel.
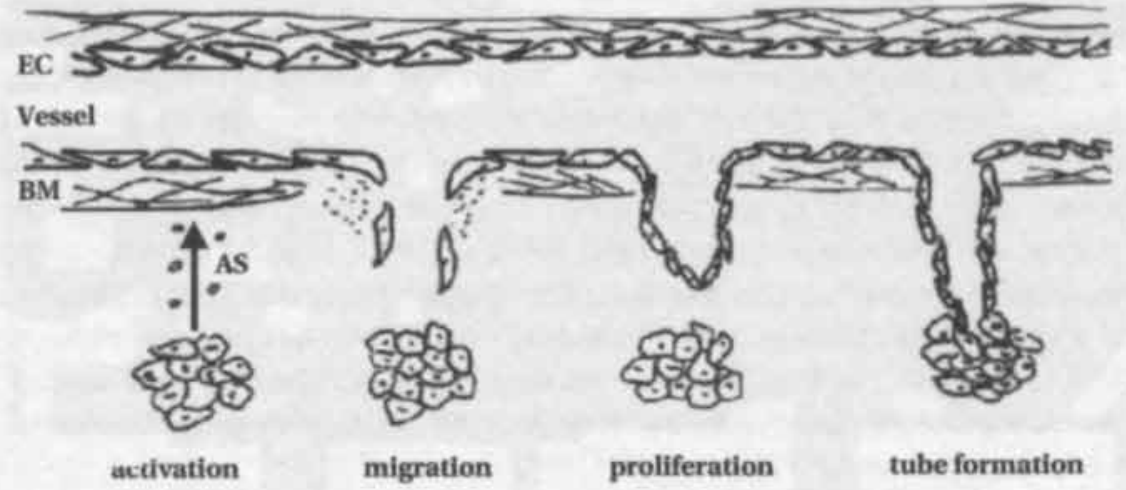

Figure 2 Sprouting angiogenesis. An angiogenic stimulus (AS) arise from a given tissue and activates endothelial cells (EC) to secrete proteolytic enzymes. Degradation of the basement membrane (BM) is followed by migration and proliferation of endothelial cells, tube formation in the endothelial sprout and finally maturation of the vessel (Griffioen et al., 1998).

Non-sprouting angiogenesis can occur by proliferation of endothelial cells inside a vessel, producing a wide lumen that can be divided by transcapillary pillars of periendothelial cells (intussusception) or by transendothelial cell bridges, which then split into individual capillaries (Patan et al., 1996; 1997; Risau, 1997; Carmeliet, 2000).

In the adult, physiological angiogenesis only occurs under special circumstances. Exceptions are seen in the female reproductive system, where angiogenesis is found in the follicle, the corpus luteum, the endometrium and the placenta. Angiogenesis also occurs as part of the body's repair processes, e.g. in the healing of wounds and fractures (Klagsbrun and D'Amore, 1991). Many diseases are characterized by angio-

Table 2 Examples of the occurrence of angiogenesis

Physiological angiogenesis

female reproductive cycle

folliculogenese

formation of the corpus luteum

development of the endometrium

implantation and placentation

wound repair

\section{Pathological angiogenesis}

cancer

diabetic retinopathy

arthritis

psoriasis

atherosclerosis

hemangioma 
genesis, e.g. diabetic retinopathy, psoriasis, hemangiomas and arthritis (Table 2). In physiological conditions angiogenesis subsides or is turned off once the process is completed. In nonmalignant processes, angiogenesis is prolonged, although still selflimiting. By contrast, tumor angiogenesis is not self-limiting (Folkman, 1985).

Angiogenesis has been suspected to be an essential component of tumor growth and metastasis. In the early 1970 s it became clear that one or more diffusible factors are released from the tumor to nearby endothelial cells, which then divide and form new capillary sprouts. In the absence of neovascularization solid tumors stop growing when they are $2-3 \mathrm{~mm}$ in size. Every increase in tumor cell population has to be preceded by an increase in new capillaries that converge upon the tumor (Folkman, 1971). The formation of metastases is dependent on angiogenesis at two stages of the metastatic cascade. First, the new blood vessels provide a gateway for tumor cells to enter the circulation and to metastasize to distant sites. Second, metastatic tumor cells must again undergo neovascularization if a metastasis is to grow to a clinically detectable size (Folkman and Shing, 1992; Folkman, 1995). In some patients, metastases develop many years after resection of the primary neoplasm. The sudden conversion of quiescent cells to actively dividing cells could occur by a progression in cell cycle from G0 to G1. The end of tumor dormancy may be explained by a sudden conversion of a subset of tumor cells to a clone with the angiogenic phenotype: the socalled 'angiogenic switch' (Fidler and Ellis, 1994).

Capillary blood vessels consist of endothelial cells and pericytes, and these two cell types have the genetic potential to form tubes, branches and whole capillary networks. Specific angiogenic molecules can initiate this process, and specific inhibitory molecules can stop it. The first angiogenic factor was isolated from Walker 256 carcinoma grown in rats by Folkman and coworkers (1971). Angiogenic factors are secreted by tumor cells, but can also be mobilized from extracellular matrix or released by macrophages attracted to the tumor (Folkman, 1995). The search for angiogenesis inhibitors was stimulated by the concept of anti-angiogenic therapy. The first to be identified were endogenous molecules, such as angiostatic steroids and platelet factor 4 (Folkman, 1992). Since angiogenic factors and inhibitors have been discovered recently (Table 3 ), the elucidation of their precise actions and interactions is only beginning to be uncovered (reviewed by Carmeliet, 2000). The same goes for non-vascular cells, such as macrophages and mast cells, which may modulate the angiogenic response (Folkman and Shing, 1992; Carmeliet, 2000). Angiogenesis involves extensive interplay between cells, soluble factors and extracellular matrix components. Some angiogenic peptides (e.g. acidic fibroblast growth factor [aFGF], basic FGF, vascular endothelial growth factor [VEGF]) stimulate vascular endothelial cells directly to either migrate or proliferate or to form tubes or a combination of these, while others (tumor necrosis factor- $\alpha$ [TNF- $\alpha$ ] and transforming growth factor- $\beta$ [TGF- $\beta$ ]) act indirectly by mobilizing host cells (macrophages, mast cells, lymphocytes) that release endothelial cell growth factors. The activity of these factors is counter-balanced by endogenous inhibitors of angiogenesis (Fan et al., 1995). This balance of angiogenesis inhibitors and inducers governs the angiogenic switch. Either reducing 
the inhibitor concentration or increasing the activator levels may change the balance and activate the switch, leading to the growth of new blood vessels (Hanahan and Folkman, 1996).

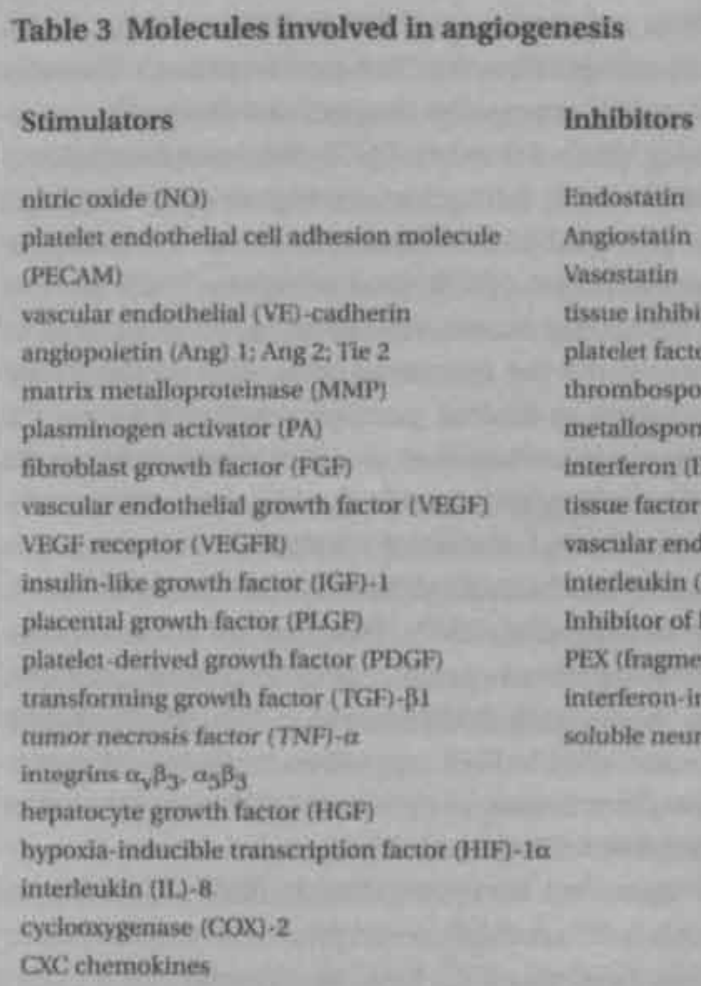

\section{Angiogenesis in the normal endometrium}

In the healthy adult angiogenesis is rare, apart from the female reproductive system where angiogenesis occurs in the follicle, corpus luteum and endometrium. Under these physiological circumstances angiogenesis is highly regulated, with subsequent periods in which it is turned on followed by periods in which it is completely inhibited. In the female reproductive tract, defects in angiogenesis have been suggested as a putative cause of some disorders such as luteal phase defects, endometriosis, pregnancy loss, preeclampsia and cancer (Findlay, 1986; Klagsbrun and D'Amore, 1991; Folkman and Shing, 1992; Gordon et al., 1995). Angiogenesis in the human uterus is mandatory to support the reconstruction of the endometrium after menstruation and to provide a vascularized, receptive endometrium for implantation and placentation (Torry et al., 1996). Although endometrium tissue is easily obtainable, making it possible to study physiologic angiogenesis on a large scale, it is still not clear by which mechanism vascular growth in the endometrium is controlled or when exact- 
ly new blood vessel formation occurs during the menstrual cycle (Rogers, 1996).

In endometrium, much attention has been paid to the expression of VEGE, one of the well-characterized angiogenic factors. VEGF mRNA expression was seen in glandular epithelium throughout the menstrual cycle with an increase in the secretory phase culminating in very intense hybridization signal in menstrual tissue (Charnock-Jones et al., 1993; Torry et al., 1996). Shifren and coworkers (1996) found increasing mRNA expression from early proliferative, mid proliferative, late proliferative to secretory endometrium. In stroma the VEGF mRNA expression disappeared during the secretory phase (Charnock-Jones et al., 1993). Likewise, VEGF-like-immunoreactivity could be detected in glandular epithelial cells throughout the menstrual cycle, and in the stroma only in the proliferative phase (Li et al., 1994; Shifren et al., 1996). On the other hand, recently Donnez and coworkers (1998), evaluating the VEGF protein immunohistochemically, did not detect significant variations in VEGF content of glandular epithelium or stroma throughout the menstrual cycle. Also no significant differences were found in VEGF secretion by explant, glandular epithelial or stromal cell cultures throughout the menstrual cycle (Gargett et al., 1999). Since endometrial growth and function are controlled mainly by sex steroids, the influence of these steroids on VEGF expression has been studied. Estradiol stimulated an increase in mRNA encoding VEGF in endometrial carcinoma cell lines (Charnock-Jones et al., 1993) and in cultured stromal cells (Huang et al., 1998). Treatment of isolated endometrial cells with estradiol, medroxyprogesterone acetate, or a combination of these, increased VEGF mRNA expression significantly (Shifren et al., 1996). In primates it has been shown that VEGF protein and VEGF mRNA expression levels in endometrium depend on the steroidal milieu. In response to treatment with a progesterone antagonist VEGF production was inhibited (Greb et al., 1997).

An additional stimulator of VEGF expression is hypoxia (Smith, 1997; 1998). During the (pre)menstrual phase of the cycle both production and release of endothelins by endometrial cells are increased (Ohbuchi et al., 1995). Besides, a very intense staining of Angiotensin (ANG) II has been found around the endometrial blood vessels in the late secretory phase (Ahmed et al., 1995). These potent vasoconstrictors act on the spiral arterioles in the endometrium, resulting in reduction of oxygen tension in this tissue (Smith, 1998). The endometrial epithelial and stromal cells respond to this hypoxic state by producing increasing levels of VEGF (Popovici et al., 1999; Sharkey et al., 2000).

Other growth factors that have been studied are aFGF, bFGF, TGF- $\beta$ and ANG II. Ferriani and coworkers (1993) detected aFGF- and bFGF-like immunoreactivity in endometrium throughout the menstrual cycle. Using Northern blotting and densitometric scanning of autoradiograms, Casslén and coworkers (1998) found TGF- $\beta$ mRNA to be higher in mid and late secretory and menstrual phases than in the proliferative phase. A significant increase was obtained after stimulation with estradiol and progesterone in vitro. Furthermore, TGF- $\beta 1$ is able to stimulate endometrial stromal cells to increase their extracellular concentration of the urokinase plasminogen activator:plasminogen activator inhibitor 1 complex, which stimulates endothelial cell migration (Sandberg et al., 1998). ANG II is not only a vasoconstrictor, but may 
also act as an angiogenic growth factor. It has been demonstrated that ANG II-likeimmunoreactivity in human endometrium undergoes cyclic changes. Staining was located in the glandular epithelium and stroma in the early proliferative phase and the staining intensified around the blood vessels in the late secretory phase (Ahmed et al., 1995; Li and Ahmed, 1996).

Lately, some studies have been published on inhibitors of angiogenesis in endometrium. Thrombospondin-1 (TSP-1) was expressed at high levels in the functional layer of the endometrium. The peak of expression occurred during the secretory phase and was coincident with the cessation of capillary growth. TSP-1 mRNA and protein were upregulated by progesterone and the increased levels were sufficient to inhibit the migration of endothelial cells (Iruela-Arispe et al., 1996). When female mice were chronically treated with AGM-1470, a highly selective, potent and nontoxic inhibitor of angiogenesis, inhibition of endometrial maturation was observed (Klauber et al., 1997).

Bioassays have been applied as well to study endometrial angiogenesis. Using a three-dimensional collagen matrix/bovine aortic endothelial cell assay to demonstrate production of an endothelial migratory signal by human endometrium, it was shown that two significant peaks of migratory signal occur, one during the early proliferative phase and one during the mid-late proliferative phase. There was a significant drop in the early-mid-proliferative phase of the cycle (Rogers et al., 1992). However, significant peaks of endometrial endothelial cell proliferation could not be identified nor a correlation with endometrial endothelial cell migratory signal production (Goodger and Rogers, 1994). Furthermore, it was observed that endothelial cell proliferation nearly always appeared inside existing endometrial vessels, rather than in vascular sprouts (Rogers et al., 1998), Also, endothelial cell integrin $\alpha_{v} \beta_{3}$ expression, a marker associated with sprouting angiogenesis, did not significantly correlate with the proliferation index and showed no difference across the cycle (Hii and Rogers, 1998). Because of these observations, Rogers and coworkers (1998) suggested that angiogenesis is occurring continuously throughout the menstrual cycle and that endometrial angiogenesis proceeds by elongation and intussusception rather than sprout formation.

Endometrial angiogenesis has also been studied using the in vivo chick embryo chorioallantoic membrane (CAM) bioassay. In a study to improve quantitative assessment of angiogenesis by the CAM assay, endometrial slices of 9 patients - cycle day was not mentioned - were placed on the CAM as a negative control; five did not respond and four gave a response of 0.1-1.0 (arbitrary units from 0-4), indicating a very low angiogenic level (Splawinski et al., 1988). A modified CAM assay was used to measure the angiogenic activity of suspensions of endometrial cells. The reactions on the CAM were assessed as having either a positive or a negative angiogenic response. In contrast to the study of Splawinski and coworkers (1988), significantly more positive reactions were seen with endometrial suspensions as compared to medium only. There were no differences between the phases (Peek et al., 1995). 


\section{Angiogenesis and endometriosis}

Angiogenesis may play an important role in the pathophysiology of endometriosis. At laparoscopy most of the typical endometriotic lesions are surrounded by a hypervascularized area and extrapelvic endometriosis, though rare, is predominantly found in well-vascularized sites such as lung, skin and muscle (Oosterlynck et al., 1993; Gordon et al., 1995). Moreover, increased endothelial cell proliferation in eutopic endometrium of endometriotic patients (Wingfield et al., 1995), and increased angiogenesis in endometrial explants (Nisolle et al., 1993) have been found.

Besides the importance of the growth factors expressed by the explants, the peritoneal fluid of women with endometriosis has been shown to contain angiogenic as well as other growth factors, which may contribute to the proliferation of the ectopic endometrium (Ramey and Archer, 1993). To support the hypothesis that local factors are important for the development of endometriosis the presence of angiogenic factors in peritoneal fluid was investigated using the CAM assay (Oosterlynck et al., 1993). A positive angiogenic reaction in $58.3 \%$ of the peritoneal fluid samples from women with endometriosis and only in $12.5 \%$ of the women without endometriosis was demonstrated. This observation has been confirmed by Taylor and coworkers (1997) using an in vitro model of endothelial cell proliferation. An increase of the influx of macrophages and their activation, as well as their release of active substances into the peritoneal fluid of women with endometriosis, had already been demonstrated (Halme et al., 1983; 1987; Dunselman et al., 1988). Therefore, Oosterlynck (1993) and Taylor (1997) both hypothesized that the angiogenic factors could originate from peritoneal macrophages. Indeed, it has been shown that the angiogenic activity in supernatants collected from macrophage cultures, was significantly higher from cells taken from women with endometriosis, as compared to women without the disease (Smith, 1997). A wide range of macrophage products with angiogenic activity (Sunderkötter et al., 1994), including TGF- $\beta$ (Oosterlynck et al., 1994; Küpker et al., 1998), TNF- $\alpha$ (Eisermann et al., 1988; Taketani et al., 1992; Overton et al., 1996) , IL-1 (Fakih et al., 1987; Mori et al., 1992; Taketani et al., 1992), IL-5 and IL-6 (Koyama et al., 1993), IL-8 (Ryan et al., 1995; Arici et al., 1996; Taylor et al., 1997; Gazvani et al., 1998; Iwabe et al., 1998) and VEGF (Mc Laren et al., 1996a; Shifren et al., 1996; Taylor et al., 1997; Küpker et al., 1998) has been found in higher concentrations in the peritoneal cavity of endometriotic patients as compared to control women.

It has been demonstrated that the concentration of VEGF in the peritoneal fluid of women with endometriosis, was significantly higher in the proliferative phase than in the secretory phase. At this phase of the cycle the increased angiogenic activity may help the implant to become revascularized and to subsequently proliferate (McLaren et al., 1996a). Furthermore, McLaren and coworkers (1996b) demonstrated that activated macrophages are a major source of VEGF in endometriosis patients. They found a limited expression of VEGF in ectopic tissue and suggested that VEGF in the peritoneal cavity of women with endometriosis, is not derived from ectopic endometrium but rather from activated peritoneal fluid macrophages. In contrast, Shifren and colleagues (1996) showed that, similar to its localization in eutopic endometrium, VEGF was expressed in glandular epithelium of endometriotic lesions. They con- 
cluded that both endometriosis implants and peritoneal macrophages are likely sources of VEGF found in peritoneal fluid.

Retrogradely shed endometrial cells may also be a source of angiogenic factors. Menstruation is characterized by constriction of the spiral arterioles, which results in distal ischemia in those parts that are shed at menstruation (Smith, 1997). Indeed, VEGF mRNA expression was seen in greatest intensity of hybridization in menstrual glandular epithelium (Charnock-Jones et al., 1993; Torry et al., 1996). When this menstrual tissue reaches the peritoneal cavity, it may be an additional source of the increased peritoneal fluid concentration of VEGF in the proliferative phase of the menstrual cycle. Furthermore, when this retrogradely shed menstrual tissue adheres to the peritoneal lining it may also be able, because of its increased content of angiogenic factors, to induce its own blood supply for further outgrowth, independent of the peritoneal environment.

\section{Angiogenesis assays}

Many disciplines of medicine and biology are concerned with angiogenesis and a vast variety of procedures have been used to study angiogenesis. To investigate factors that influence angiogenesis and to gain a more fundamental understanding of the cellular processes involved in the generation of capillaries, a number of in vivo and in vitro assays of angiogenesis have been developed (Table 4) (Auerbach et al., 1991; Knighton et al., 1991; Cockerill et al., 1995; Jain et al., 1997). A few models will only be briefly discussed. The chick embryo CAM angiogenesis assay, which was used in the studies described in this thesis, will be discussed in detail in the following section.

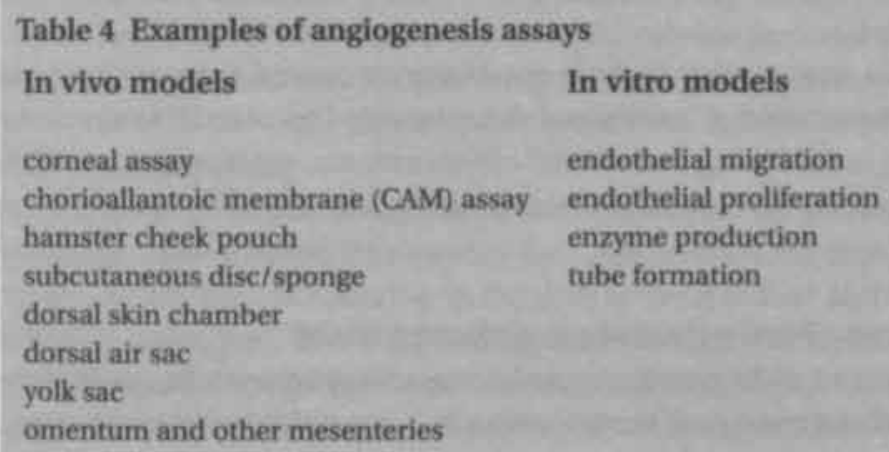

\section{In vivo assays of angiogenesis}

\section{- Rabbit corneal assay}

The induction of an angiogenic reaction in the cornea has to be considered as the most convincing demonstration of true neovascularization, since the cornea is normally completely avascular. After 7 days, the angiogenic response is quantified on a 0 to 4 scale. Advances in image analysis have improved the capacity to quantitate this 
corneal model. This model is expensive and only a small number of samples can be tested at the same time.

- Disc angiogenesis assay

Polyvinyl alcohol sponges impregnated with angiogenic factors are introduced subcutaneously in the experimental animals and evaluated for penetration by host-derived blood vessels.

- Hamster cheek pouch

Xenogeneic grafts can grow in this pouch without eliciting an immune response. The blood vessel growth is observed through a transparent chamber.

- Dorsal skin chamber

A transparent window is inserted in the skin, through which angiogenesis resulting from an implant can be monitored. Using an in vivo assay, one must be aware that any procedure, tissue or substance, which invokes an inflammatory response in the assay system could cause angiogenesis. To control for this, careful daily inspection of the assay site with histological examination is mandatory to detect inflammation.

\section{In vitro assays of angiogenesis}

The cellular activities of angiogenesis include migration, proliferation and tube formation, which can be assayed in vitro. The ideal cell type to be used for in vitro assays is the venular capillary endothelium or the small venular endothelium. Usually, human umbilical vein endothelial cells (HUVECs) are seeded onto collagen or Matrigel. Counting the cells that migrate preferentially toward a stimulus may well be the most reliable measure of a direct response of endothelial cells to angiogenic factors. Proliferation of endothelial cells, after culture in the presence of test factors, can be determined by cell counts, DNA incorporation, or staining techniques. Tube formation can be affected by adding a variety of substrates after confluence of endothelial cells is established.

The advantages of in vitro models include the ability to control the experimental variables, the easy monitoring of events and the relatively low costs. However, any molecule promoting or inhibiting endothelial cell movement, proliferation or differentiation in vitro may not necessarily evoke angiogenesis in vivo.

\section{The chick embryo chorioallantoic membrane (CAM)}

In birds, the development of the embryo cannot occur without the mediation of temporary appendages that persist until the transition to independent existence occurs. These appendages are the extraembryonic membranes. They consist of the yolk sac, the amnion, the chorion, and the allantois. The functions of the membranes are the vital ones of nourishment, protection, respiration, and the segregation of waste products. The chorion and the allantois form the chorioallantois, an extension that encloses the albumen, known as the albumen sac. It is formed on day 4 of incubation, when the outer mesodermal layer of the allantois fuses with the mesodermal lining of the chorion. The chorionic ectoderm (CE) and the allantoic endoderm (AE) are also incorporated into the new membrane, which is thus composed of three germ layers. 
By day 12 or 13 the chorioallantois lines the entire shell membrane and its expansion is complete. The chorioallantois exerts the function of a lung during embryonic life. The capillary network is situated directly beneath the shell membranes, as close as possible to the source of oxygen. This proximity to the external atmosphere, together with its large surface area and its rich capillary network makes the chorioallantois extremely well adapted to its respiratory function (Romanoff, 1960).

\section{Transplantation}

The first record of tumor implantation in the fertile egg was by Rous and Murphy (1911), who tried to implant chicken sarcoma in the developing chick embryo. They injected a minute portion of tumor into the chick embryo. However, at the end of the experiment they observed that the tumor was growing into the CAM with dilated blood vessels converging to and coursing over the tumor mass. Apparently, during the injection part of the tissue had fastened onto the membranes and started to grow. In subsequent studies Murphy $(1912 ; 1914)$ inoculated tumors of foreign species on purpose into the CAM and observed that these tumor tissues grew actively in the chick embryo CAM until the onset of a refractory period, which started after day 18 of incubation, as the time of hatching approached. Later it became clear that the alloimmune responsiveness exists as late as day $17-18$ of chick embryo development. After 18 days of incubation the antibody output improves considerably and grafted cells will be rejected from then onwards (Seto, 1971). Thus, the developing chick embryo has no defense against the growth of heterologous tissue, and it will supply blood vessels and connective tissue for the growth of these tumors. Also human cells, malignant as well as normal, were frequently able to survive and even to multiply on the CAM (Hurst et al., 1939). Karnofsky and coworkers (1952) explanted 71 human tumors, freshly obtained by biopsy to the CAM. In general, these tumors grew very poorly, and only in a few cases evidence for cell survival and mitotic activity was obtained. It was observed that small fragments of tissue, $1-2 \mathrm{~mm}$, in diameter, placed on the CAM of the eight-day embryo, caused the maximum effect on the embryo about three days later.

Since Rous and Murphy (1911) introduced chorioallantoic grafting it has been widely applied. Their method for exposing the CAM is called the classical artificial air sac technique. They made a window in the shell at day 8 or later and by applying suction to the air space, the CAM dropped away from the shell membrane, resulting in trauma in the part of the membrane under the shell. Zwilling (1959) modified their grafting technique to make it more effective and to eliminate some uncertainties, including non-specific membrane reactions. Instead of making a window at day 8 or later, a window was made at day 3 , before the CAM is formed. Now a clean untraumatized membrane is available for use. With this technique, however, the membrane is too intact for consistent incorporation of tissue and deliberate superficial laceration, for example with a sharp steel needle, to assure a good take is required (Zwilling, 1959). The techniques of heterologous transplantation of tumor tissue onto the CAM are simple and mortality due to the inoculation procedure itself is small. However, results vary depending upon the tumor used. Even in the same experiment, divergent results 
are sometimes observed. When the tumor has been accepted, the fragment is found in the mesenchyme of the CAM after a few days and its vascular bed contains nucleated red blood cells of the chick embryo. The architecture of the inoculated tissue is usually maintained. The CAM has mainly been used for cancer research and the search for therapeutic possibilities. For example, a decrease in expected weight of tumor nodules on the CAM after application of a drug in the yolk sac, can be used as a measure of therapeutic response. With the appearance of many continuous lines of human cells, of normal as well as cancerous origin, the work with cell suspensions has been introduced in the cancer research laboratory to study their biological differences (Leighton, 1964).

Decennia later the CAM became a subject of renewed interest as an inexpensive and readily available substrate for assaying the invasive, metastatic and angiogenic potential of neoplastic cells (Scher et al., 1976; Armstrong et al., 1982). At this time, with the use of electron microscopy, it was possible to obtain more detailed information about the anatomy of the CAM, particularly the chorionic surface and chorionic blood sinuses. Furthermore, one could compare the two different methods for exposing the CAM: the classical air sac technique (Rous and Murphy, 1911) or the Zwilling technique (Zwilling, 1959), which does not involve dropping of the membrane and would eliminate the possibility of traumatic damage of the chorion. Electron microscopic examination showed that at day 10 of incubation the chorionic epithelium of the Zwilling CAM is a continuous double layer of cells with a superficial sheet of flat peridermal cells and a basal cell layer. The epithelial layer rests on a thin basement membrane directly above the underlying blood sinus, which is lined by endothelial cells. Dropped CAMs show severely damaged chorionic epithelial cells, but the basement membrane is complete and resistant to mechanical disruption. If the CAM serves as a substrate for assaying invasive potential of cells then it is reasonable to expose every inoculum to the same barrier. The dropped CAM presents a far too heterogeneous surface (Armstrong et al., 1982; McCormick et al., 1984).

\section{Invasion}

The CAM is a readily accessible tissue, which allows analysis of invasiveness prior to tumor formation. The cells inoculated onto the CAM can be directly observed, unlike studies with animal models (Scher et al., 1976). Advantages of the CAM as a model system for the study of invasion include: (a) embryos can be obtained that are pathogen free; (b) until day 18 of incubation, the embryo is immunological incompetent; and (c) the ability of tumor cells to traverse the CE and establish contact with the mesenchymal layer can be used as a convenient and easily scored end point for invasion.

A modified Zwilling technique was introduced by Armstrong and coworkers (1982). They gently traumatized the CAM by laying a 1-cm-wide strip of sterile ether-extracted lens tissue onto the surface of the $\mathrm{CE}$ and then removing it immediately. With this technique the periderm was disrupted, but the basal cell layer was left intact. They showed that the untraumatized CE is a impenetrable barrier to cells of invasive tumor lines and that tumor cells but also some normal cells are able to gain access to the 
mesoderm when placed on the traumatized CAM (Armstrong et al., 1982). Schroyens and coworkers (1989) used two cell lines, of which the invasive and non-invasive character was documented in another system, in the CAM model to test for similar behaviour. Their results suggested that the traumatized CAM is a good model to differentiate between invasive and non-invasive epithelial cells.

\section{Angiogenesis}

Although the reactions of the CAM to tissue grafts had been described, the events leading to revascularization of such implants and the role played by the host and/or graft blood vessels in the reestablishment of a blood supply were less well understood. Therefore, Ausprunk and coworkers (1975) studied the neovascularization of heterologous tumor implants by in vivo stereomicroscopy and in histologic sections. The tissues underwent necrosis of central parenchymal cells during the first 2 days and the original graft blood vessels slowly degenerated. The regions of the grafts closest to the CAM mesoderm and its blood vessels remained viable even though most grafts were never revascularized. The small CAM blood vessels, which were increased in number near the graft margin, occasionally penetrated a short distance into the graft. Further experiments showed that tumor growth could be divided into an initial avascular phase, followed by a vascular phase. Tumor implants, although surrounded by vessels, only grew until they were penetrated by newly formed vessels. The onset of this required angiogenesis occurred after 72 hours. The vascular response was graded as 0 (no difference in vessel pattern), $1+$ (convergence of a few vessels toward the tumour implant) or $2+$ (an increased density and length of vessels converging toward the implant). Changes in the vasculature of the CAM in response to tumors were not grossly observable until after the 10th day of incubation. The CAM endothelium has a high mitotic rate until day 10 of incubation (Ausprunk et al., 1974), thus the angiogenic reaction might be masked by the normally high activity of growing vessels. Therefore, to detect the altered pattern of the CAM vessels in response to a graft, the experiment should be started at day 10 or 11 of incubation (Knighton et al., 1977).

In addition to studying tumor grafts, Folkman and coworkers (1985) also examined the effect of isolated angiogenic factors by placing them on coverslips, permitting the test substances to dry and then laying the coverslips onto the CAM. The test substances can also be dissolved in methyl cellulose, which is then dried to make disks and placed onto the CAM. This method has been applied to study angiogenesis inducers as well as inhibitors (Folkman, 1985). Subsequently, different carrier materials have been introduced, including Millipore filter discs, Elvax polymer pellets, Thermanox tissue culture coverslips, glass fiber prefilters and collagen gel (Barnhill and Ryan, 1983; Dusseau et al., 1986; Wilting et al., 1991; Oosterlynck et al., 1993, Ngyuen et al., 1994). With all these application materials, it is difficult to apply a standard amount of a certain factor onto the CAM. Dissolved substances can be applied in standard amounts within a silicon ring, which was placed onto the CAM (Le Noble et al., 1993). When angiogenic substances are tested, a vasoproliferative response will be recognizable 72-96 hours after implantation: the response takes the form of increased vessel density around the implant, with the vessels radially converging towards the centre, 
like spokes in a wheel. When anti-angiogenic substances are tested, then vessels become less dense around the implant after about $72-96$ hours, and eventually disappear (Ribatti et al., 1996).

Quantitation of this assay was initially done by scoring the extent of vascularization on a graded scale of 0-4 (Vu et al., 1985). However, this method makes it very difficult to compare results with the aid of statistical analysis. Several investigators have tried to develop a more objective method of quantitation. Jacob and coworkers (Jakob and Voss, 1984; Voss et al., 1984) quantitated the vascular response by using automatic image analysis. The application of stereological principles to the analysis of microcirculation, on the other hand, represents a useful tool for obtaining quantitative information (Schmid-Schoenbein et al., 1977). Therefore, several stereological techniques have been described to quantitate the angiogenic response in the CAM (Barnhill and Ryan 1983; Harris-Hooker et al., 1983; Dusseau et al., 1986). A Vascular Density Index (VDI) was calculated by counting the number of intercepts of vessels with concentric circles of a grid, which was placed over the formalin fixed CAM, or over a photograph of the excised membranes. The VDI obtained in this way is an estimate of arteriolar and venular number and length (Dusseau et al., 1988). However, Strick and coworkers (1991), comparing different morphometric measurements of vascularity, concluded that VDI is a function of vessel length rather than number of vessels. Splawinski and coworkers (1988) attempted to quantitate angiogenesis by measuring total incorporation of tritiated thymidine to cells in the CAM. Angiogenesis is the formation of new vessels, but sometimes it is difficult to distinguish the new from the existing vessels. Nguyen and coworkers (1994) dealt with that problem by counting only the vessels, that grew vertically from the surface of the CAM into a collagen gel. None of all these methods has yet been fully validated. 


\section{References}

Ahmed, A., L, X.E, Shams, M., Gregory, J., Rollason, T., Barnes, N.M. and Newton, J.R. (1995) Localization of the Angiotensin II and its receptor subtype expression in human endometrium and identification of a novel high-affinity Angiotensin II binding site. J.Clin. Invest., 96, 848-857.

Andreasen, P.A., Egelund, R. and Petersen, H.H. (2000) The plasminogen activation system in tumor growth, invasion, and metastasis. Cell. Mol. Life. Sci., 57, 25-40.

Arici, A., Tazuke, S.I., Attar, B., Kliman, H.J. and Olive, D.L. (1996) Interleukin-8 concentration in peritoneal fluid of patients with endometriosis and modulation of interleukin-8 expression in human mesothelial cells. Mol. Hum. Reprod., 2, 40-45.

Armstrong, P.B., Quigley, J.P. and Sidebottom, B. (1982) Transepithelial invasion and intramesenchymal infiltration of the chick embryo chorioallantois by tumor cell lines. Cancer Res., 42, 1826-1837.

Auerbach, R., Auerbach, W. and Polakowski, 1. (1991) Assays for angiogenesis: a review. Pharmac. Ther., 51, 1-11.

Ausprunk, D.H., Knighton, D.R. and Folkman, J. (1974) Differentiation of vascular endothelium in the chick chorioallantois: a structural and autoradiographic study. Dev, Biol., 38, 237-248.

Ausprunk, D.H., Knighton, D.R. and Folkman, J. (1975) Vascularization of normal and neoplastic tissues grafted to the chick chorioallantois. Am. J. Pathol., 79, 597-618. Badawy, S.Z.A., Cuenca, V., Marshall, L, Munchback, R., Rinas, A.C. and Coble, D.A. (1984) Cellular components in peritoneal fluid in infertile patients with and without endometriosis. Fertil. Steril., 42, 704-708.

Balasch, J., Creus, M., Fabregues, F, Carmona, E, Ordi, J., Martinez-Roman, S. and Vanrell, J.A. (1996) Visible and non-visible endometriosis at laparoscopy in fertile and infertile women and in patients with chronic pelvic pain: a prospective study. Hum. Reprod., 11, 387-391.

Barnhill, R.L. and Ryan, T.J.R. (1983) Biochemical modulation of angiogenesis in the chorioallantoic membrane of the chick embryo. J. Invest. Derm., 81, 485-488.

Bartosik, D., Jacobs, S.L. and Kelly, L.J. (1986) Endometrial tissue in peritoneal fluid. Fertil. Steril., 46, 796-800.

Bruner, K.L., Matrisian, L.M., Rodgers, W.H., Gorstein, E and Osteen, K.G. (1997) Suppression of matrix metalloproteinases inhibits establishment of ectopic lesions by human endometrium in nude mice. J. Clin. Invest., 99, 2851-2857.

Carmeliet, P. (2000) Mechanisms of angiogenesis and arteriogenesis. Nat. Med., 6, 389-395.

Casslén, B., Sandberg, T., Gustavsson, B., Willen, R. and Nilbert, M. (1998) Transforming growth factor $\beta 1$ in the human endometrium. Cyclic variation, increased expression by estradiol and progesterone, and regulation of plasminogen activators and plasminogen activator inhibitor-1. Biol. Reprod., 58, 1343-1350.

Charnock-Jones, D.S., Sharkey, A.M., Rajput-Williams, J., Burch, D., Schofield, J.P.,

Fountain, S.A., Boocock, C.A. and Smith, S.K. (1993) Identification and localization of alternately spliced mRNAs for Vascular Endothelial Growth Factor in human uterus and estrogen regulation in endometrial carcinoma cell lines. Biol. Reprod., 48, 
Cockerill, G.W., Gamble, J.R. and Vadas, M.A. (1995) Angiogenesis: models and modulators. Int. Rev, Cytol., 159, 113-160.

Curran, S. and Murray, G.I. (1999) Matrix metalloproteinases in tumour invasion and metastasis. J. Pathol., 189, 300-308.

Curran, S. and Murray, G.I. (2000) Matrix metalloproteinases: molecular aspects of their roles in tumour invasion and metastasis. Eur. J. Cancer. 36, 1621-1630.

Donnez, J., Smoes, R., Gillerot, S., Casanas-Roux, F. and Nisolle, M. (1998) Vascular endothelial growth factor (VEGF) in endometriosis. Hum. Reprod., 13, 1686-1690.

Dunselman, G.A.J., Hendrix, M.G.R., Bouckaert, PX.J.M. and Evers, J.L.H. (1988) Functional aspects of peritoneal macrophages in endometriosis of women. J. Reprod. Fertil., 82, 707-710.

Dusseau, J.W., Hutchins, P.M. and Malbasa, D.S. (1986) Stimulation of angiogenesis by adenosine on the chick chorioallantoic membrane. Circ. Res., 59, 163-170.

Dusseau, J.W. and Hutchins, P.M. (1988) Hypoxia-induced angiogenesis in chick chorioallantoic membranes: a role for adenosine. Respir. Physiol., 71, 33-44.

Eisermann, J., Gast, M.J., Pineda, J., Odem, R.R. and Collins, J.L. (1988) Tumor necrosis factor in peritoneal fluid of women undergoing laparoscopic surgery. Fertil. Steril., 50, 573-579.

Ellenrieder, V., Adler, G. and Gress, T.M. (1999) Invasion and metastasis in pancreatic cancer. Ann. Oncol., 10, 46-50.

Evers, J.L.H., Land, J.A., Dunselman, G.A.J., Van der Linden, PJ.Q. and Hamilton, C.J.C.M. (1998) The Flemish Giant, reflections on the defense against endometriosis, inspired by Professor Emeritus Ivo A. Brosens. Eur. J. Obstet. Gynecol. Reprod. Biol., 81, 253-258.

Fakih, H., Bagget, B., Holtz, G., Tsang, K., Lee, J.C. and Williamson, H.O. (1987) Interleukin-1: a possible role in the infertility associated with endometriosis. Fertil. Steril., 47, 213-217.

Fan, T.D., Jaggar, R. and Bicknell, R. (1995) Controlling the vasculature: angiogenesis, anti-angiogenesis and vascular targeting of gene therapy. Trends Pharmacol. Sci., 16, 57-66.

Ferriani, R.A., Charnock-Jones, D.S., Prentice, A., Thomas, E.J. and Smith, S.K. (1993) Immunohistochemical localization of acidic and basic fibroblast growth factors in normal human endometrium and endometriosis and the detection of their mRNA by polymerase chain reaction. Hum. Reprod., 8, 11-16.

Fidler, I.J. and Ellis, L.M. (1994) The implications of angiogenesis for the biology and therapy of cancer metastasis. Cell, 79, 185-188.

Findlay, J.K. (1986) Angiogenesis in reproductive tissues. J. Endocr., 111, 357-366.

Folkman, J. (1971) Tumor angiogenesis: therapeutic implications. N. Engl. J. Med., 285, 1182-1186.

30 Folkman, J., Merler, E., Abernathy, C. and Williams, G. (1971) Isolation of a tumor factor responsible for angiogenesis. J. Exp. Med., 133, 275-288.

Folkman, J. (1985) Tumor angiogenesis. Adv. Cancer Res., 43, 175-203.

Folkman, J. (1992) Angiogenesis - Retrospect and outlook. EXS, 61, 4-13. 
Folkman, J. and Shing, Y. (1992) Angiogenesís. J. Biol. Chem., 267, 10931-10934.

Folkman, J. (1995) Angiogenesis in cancer, vascular, rheumatoid and other disease. Nature Med., 1, 27-31.

Friedl, P. and Bröcker, E. (2000) The biology of cell locomotion within three-dimensional extracellular matrix. Cell. Mol. Life. Sci., 57, 41-64.

Gaetje, R., Kotzian, S., Herrmann, G., Baumann, R. and Starzinski-Powitz, A. (1995) Invasiveness of endometriotic cells in vitro, Lancet, 346, 1463-1464.

Gaetje, R., Kotzian, S., Herrmann, G., Baumann, R. and Starzinski-Powitz, A. (1997) Nonmalignant epithelial cells, potentially invasive in human endometriosis, lack the tumor suppressor molecule E-cadherin. Am. J. Pathol., 150, 461-467.

Gargett, C.E., Lederman, F.L., Lau, T.M., Taylor, N.H. and Rogers, P.A.W. (1999) Lack of correlation between vascular endothelial growth factor production and endothelial cell proliferation in the human endometrium. Hum. Reprod., 14, 2080-2088.

Gazvani, M.R., Christmas, S., Quenby, S., Kirwan, J., Johnson, P.M. and Kingsland, C.R. (1998) Peritoneal fluid concentrations of interleukin-8 in women with endometriosis: relationship to stage of disease. Hum. Reprod., 13, 1957-1961.

Goodger (Macpherson), A.M. and Rogers, P.A.W. (1994) Endometrial endothelial cell proliferation during the menstrual cycle. Hum. Reprod., 9, 399-405.

Gordon, J.D., Shifren, J.L., Foulk, R.A., Taylor, R.N. and Jaffe, R.B. (1995) Angiogenesis in the human female reproductive tract. Obst. Gynecol. Surv., 50, 688-697.

Greb, R.R., Heikinheimo, O., Williams, R.F., Hodgen, G.D. and Goodman, A.L. (1997) Vascular endothelial growth factor in primate endometrium is regulated by oestrogen-receptor and progesteron-receptor ligands in vivo. Hum. Reprod., 12, 12801292.

Griffioen, A.W., Barendsz-Janson, A.F, Mayo, K.H. and Hillen, H.F.P (1998) Angiogenesis, a target for tumor therapy. J. Lab. Clin. Med., 132, 363-368.

Griffioen, A.W. and Molema, G. (2000) Angiogenesis: potentials for pharmacologic intervention in the treatment of cancer, cardiovascular diseases and chronic inflammation. Pharmacol. Rev., 52, 237-268.

Groothuis, P.G., Koks, C.A.M., de Goeij, A.F.P.M., Dunselman, G.A.J., Arends, J.W. and Evers, J.L.H. (1998) Adhesion of human endometrium to the epithelial lining and extracellular matrix of amnion in vitro: An electron microscopic study. Hum. Reprod., $13,2275-2281$.

Groothuis, P.G., Koks, C.A.M., de Goeij, A.E.P.M., Dunselman, G.A.J., Arends, J.W. and Evers, J.L.H. (1999) Adhesion of human endometrial fragments to peritoneum in vitro. Fertil. Steril., 71, 1119-1124.

Halme, J., Becker, S., Hammond, M.G., Raj, M.H.G. and Raj, S. (1983) Increased activation of pelvic macrophages in infertile women with mild endometriosis. Am. J. Obstet. Gynecol., 145, 333-337.

Halme, J., Becker, S., and Haskill, S. (1987) Altered maturation and function of peritoneal macrophages: Possible role in pathogenesis of endometriosis. Am. J. Obstet. Gynecol., 156, 783-789.

Hanahan, D. and Folkman, J. (1996) Patterns and emerging mechanisms of the angiogenic switch during tumorigenesis. Cell, 86, 353-364. 
Harris-Hooker, S.A., Gajdusek, C.M., Wight, T.N. and Schwartz, S.M. (1983) Neovascular responses induced by cultured aortic endothelial cells. J. Cell. Physiol.,114, 302310.

Hil, L.L.R and Rogers, P.A.W. (1998) Endometrial vascular and glandular expression of integrin $\alpha_{\mathrm{v}} \beta_{3}$ in women with and without endometriosis. Hum. Reprod., 13, 10301035.

Huang, J.C., Liu, D.Y. and Dawood, M.Y. (1998) The expression of vascular endothelial growth factor isoforms in cultured human endometrial stromal cells and its regulation by 17-oestradiol. Mol. Hum. Reprod., 4, 603-607.

Hulboy, D.L., Rudolph, L.A. and Matrisian, L.M. (1997) Matrix metalloproteinases as mediators of reproductive function. Mol. Human. Reprod., 3, 27-45.

Hurst, E.W., Cooke, B. and McLennan, G.C. (1939) A note on the survival and growth of human and rabbit tissues (normal and neoplastic) on the chorio-allantois of the chick and duck embryo. Austr. J. Exp. Biol., 17, 215-224.

Iruela-Arispe, M.L., Porter, P., Bornstein, P. and Sage, E.H. (1996) Thrombospondin1 , an inhibitor of angiogenesis, is regulated by progesterone in the human endometrium. J. Clin. Invest., 97, 403-412.

Ivaska, J. and Heino, J. (2000) Adhesion receptors and cell invasion: mechanisms of integrin-guided degradation of extracellular matrix. Cell. Mol. Life. Sci., 57, 16-24.

Iwabe, T., Harada, T., Tsudo, T., Tanikawa, M., Onohara, Y. and Terakawa, N. (1998) Pathogenetic significance of increased levels of interleukin- 8 in the peritoneal fluid of patients with endometriosis. Fertil. Steril., 69, 924-930.

Jain RK, Schlenger K, Höckel M and Yuan E. (1997) Quantitative angiogenesis assays: Progress and problems. Nat. Med., 3, 1203-1208.

Jakob, W. and Voss, K. (1984) Utilization of image analysis for the quantification of vascular responses in the chick chorioallantoic membrane. Exp. Pathol., 26, 93-99.

Jansen, R.P., Russell, P. (1986) Nonpigmented endometriosis: clinical, laparoscopic, and pathologic definition. Am. J. Obstet. Gynecol., 155, 1154-1159.

Jenkins, S., Olive, D.L and Haney, A.F. (1986) Endometriosis: Pathogenetic implications of the anatomic distribution. Obstet. Gynecol., 67, 335-338.

Johansson, N., Ahonen, M. and Kähäri, V. (2000) Matrix metalloproteinases in tumor invasion. Cell. Mol. Life. Sci., 57, 5-15.

Karnofsky, D.A., Ridgway, L.P. and Patterson, P.A. (1952) Tumor transplantation to the chick embryo. Ann. N. Y. Acad. Sci., 55, 313-329.

Klagsbrun, M. and D'Amore, P.A. (1991) Regulators of angiogenesis. Annu. Rev. Physiol., 53, 217-239.

Klauber, N., Rohan, R.M., Flynn, B. and D'Amato, R.J. (1997) Critical components of the female reproductive pathway are suppressed by the angiogenesis inhibitor AGM1470. Nature Med, 3, 443-446.

Knighton, D., Ausprunk, D., Tapper, D. and Folkman, J. (1977) Avascular and vascular phases of tumour growth in the chick embryo. Br. J. Cancer, 35, 347-356.

Knighton, D.R., Fiegel, V.D. and Phillips, G.D. (1991) The assay of angiogenesis. Clin. Exp. Appr. Derm. Epiderm. Rep., 291-299.

Koks, C.A.M., Groothuis, R.G., Dunselman, G.A.J., de Goeij, A.F.P.M. and Evers, J.L.H. 
(1999) Adhesion of shed menstrual tissue in an in vitro model using amnion and peritoneum: A light and electron microscopic study. Hum. Reprod., 14, 816-822.

Koks, C.A.M., Groothuis, P.G., Dunselman, G.A.J., de Goeij, A.F.P.M. and Evers, J.L.H. (2000a) Adhesion of menstrual endometrium to extracellular matrix mediated by integrin $\alpha_{6} \beta_{1}$ and laminin interaction. Mol. Hum. Reprod., 6, 170-177.

Koks, C.A.M., Groothuis, PG., Slaats, P., Dunselman, G.A.J., de Goeij, A.F.P.M. and Evers, J.L.H. (2000b) Matrix metalloproteinases and their tissue inhibitors in antegradely shed menstruum and peritoneal fluid. Fertil. Steril., 73, 604-612.

Koninckx, P.R., Kennedy, S.H. and Barlow DH. (1998) Endometriotic disease: the role of peritoneal fluid. Hum. Reprod. Update, 4, 741-751.

Koyama, N., Matsuura, K. and Okamura, H. (1993) Cytokines in the peritoneal fluid of patients with endometriosis. Int. J. Gynecol, Obstet., 43, 45-50.

Kruitwagen, R.F.P.M., Poels, L.G., Willemsen, W.N.P., de Ronde, IJ.Y., Jap, P.H.K. and Rolland, R. (1991) Endometrial epithelial cells in peritoneal fluid during the early follicular phase. Fertil. Steril., 55, 297-303.

Küpker, W., Schultze-Mosgau, A. and Diedrich K. (1998) Paracrine changes in the peri-toneal environment of women with endometriosis. Hum. Reprod. Update, 4, 719-723.

Leighton, J. (1964) Invasion and metastasis of heterologous tumors in the chick embryo. Progr. Exp. Tumor Res., 4, 98-125.

Le Noble, FA.C., Schreurs, N.H.J.S., Van Straaten, H.W.M., Slaaf, D.W., Smits, J.F.M., Rogg, H. and Struijker-Boudier, H.A.J. (1993) Evidence for a novel angiotensin II receptor involved in angiogenesis in chick embryo chorioallantoic membrane. Am. J. Physiol., 264, R460-R465.

Le Querrec, A., Duval, D. and Tobelem, G. (1993) Tumour angiogenesis. Bailleres. Clin. Haematol., 6, 711-730.

Levander, G. and Normann, R. (1955) The pathogenesis of endometriosis. Acta Obstet. Gynecol. Scand., 34, 366-398.

L, X.F., Gregory, J. and Ahmed, A. (1994) Immunolocalisation of Vascular Endothelial Growth Factor in human endometrium. Growth Factors, 11, 277-282.

L, X.E. and Ahmed, A. (1996) Dual role of angiotensin II in the human endometrium. Hum. Reprod., 11, 95-108.

McCormick, J.E., Nassauer, J., Bielunas, J. and Leighton, J. (1984) Anatomy of the chick chorioallantoic membrane relevant to its use as a substrate in bioassay systems. Scan. Electron. Microsc., IV, 2023-2030.

McLaren, J., Prentice, A., Charnock-Jones, D.S. and Smith, S.K. (1996a) Vascular endothelial growth factor (VEGF) concentrations are elevated in peritoneal fluid of women with endometriosis. Hum. Reprod., 11, 220-223.

McLaren, J., Prentice, A., Charnock-Jones, D.S., Millican, S.A., Müler, K.H., Sharkey, A.M. and Smith, S.K. (1996b) Vascular endothelial growth factor is produced by peritoneal fluid macrophages in endometriosis and is regulated by ovarian steroids. J. Clinic. Invest., 98, 482-489.

Merrill, J.A. (1966) Endometrial induction of endometriosis across Millipore filters. Am. J. Obstet. Gynecol., 94, 780-790. 
Mori, H., Sawairi, M., Nakagawa, M., Itoh, N., Wada, K. and Tamaya, T. (1992) Expression of interleukin-1 (IL-1) beta messenger ribonucleic acid (mRNA) and IL-1 receptor antagonist mRNA in peritoneal macrophages from patients with endometriosis. Fertil. Steril., 57, 535-542.

Murphy, J.B. (1912) Transplantability of malignant tumors to the embryos of a foreign species. J. Am. Med. Assoc., 59, 874-875.

Murphy, J.B. (1914) Studies in tissue specificity. II. J. Exper. Med., 19, 181-186.

Ngyuen, M., Shing,Y. and Folkman,J. (1994) Quantitation of angiogenesis and antiangiogenesis in the chick embryo chorioallantoic membrane. Microvasc. Res., 47. 31-40.

Nisolle, M., Casanas-Roux,F, Anaf,V., Mine,J and Donnez,J. (1993) Morphometric study of the stromal vascularization in peritoneal endometriosis. Fertil. Steril., 59, 681-684.

Ohbuchi, H., Nagai, K., Yamaguchi, M., Ikenoue, T., Mori, N., Kitamura, K., Araki, S. and Toshimori, K. (1995) Endothelin-1 and big endothelin-1 increase in human endometrium during menstruation. Am. J. Obstet. Gynecol, 173, 1483-1490.

Ohtake, H., Katabuchi, H., Matsuura, K. and Okamura, H. (1999) A novel in vitro experimental model for ovarian endometriosis: the three-dimensional culture of human ovarian surface epithelial cells in collagen gels. Fertil. Steril., 71, 50-55.

Oosterlynck, D.J., Meuleman, C., Sobis, H., Vandeputte, M. and Koninckx, P.R. (1993) Angiogenic activity of peritoneal fluid from women with endometriosis. Fertil. Steril., 59, 778-782.

Oosterlynck, D.J., Meuleman, C., Waer, M. and Koninckx, P.R. (1994) Transforming growth factor $\beta$ activity is increased in peritoneal fluid from women with endometriosis. Obstet. Gynecol., 83, 287-289.

Oral, E., Olive, D.L. and Arici, A. (1996) The peritoneal environment in endometriosis. Hum. Reprod. Update, 2, 385-398.

Osteen, K.G., Keller, N.R., Feltus, F.A. and Melner, M.H. (1999) Paracrine regulation of matrix metalloproteinase expression in the normal human endometrium. Gynecol. Obstet. Invest., 48 (suppl 1), 2-13.

Overton, C., Fernandez-Shaw, S., Hicks, B., Barlow, D. and Starkey, P. (1996) Peritoneal fluid cytokines and the relationship with endometriosis and pain. Hum. Reprod., 11, 380-386.

Patan, S., Haenni, B. and Burri, P.H. (1996) Implementation of intussusceptive microvascular growth in the chicken chorioallantoic membrane (CAM): 1. Pillar formation by folding of the capillary wall. Microvasc. Res., 51, 80-98.

Patan, S., Haenni, B. and Burri, PH. (1997) Implementation of intussusceptive microvascular growth in the chicken chorioallantoic membrane (CAM): 2. Pillar formation by capillary fusion. Microvasc. Res., 53, 33-52.

Peek, M.J., Markham, R. and Fraser, I.S. (1995) Angiogenic activity in normal and 34 dysfunctional uterine bleeding human endometrium; as measured by the chick chorioallantoic membrane assay. Exp. Toxic. Pathol., 47, 397-402.

Popovici, R.M., Irwin, J.C., Giaccia, A.J. and Giudice, LC. (1999) Hypoxia and cAMP stimulate Vascular Endothelial Growth Factor (VEGF) in human endometrial stromal 
cells: potential relevance to menstruation and endometrial regeneration. J. Clin. Endocrinol. Metab., 84, 2245-2248.

Ramey, J.W. and Archer, D.E (1993) Peritoneal fluid: its relevance to the development of endometriosis. Fertil. Steril., 60, 1-14.

Ribatti, D., Vacca, A., Roncali, L_ and Dammacco ,E (1996) The chick embryo chorioallantoic membrane as a model for in vivo research on angiogenesis. Int. J. Dev. Biol., 40, 1189-1197.

Risau, W. (1997) Mechanisms of angiogenesis. Nature, 386, 671-674.

Rogers, P.A.W., Abberton, K.M. and Susil, B. (1992) Endothelial cell migratory signal produced by human endometrium during the menstrual cycle. Hum. Reprod., 7 , 1061-1066.

Rogers, P.A.W. (1996) Structure and function of endometrial blood vessels. Hum. Reprod. Update, 2, 57-62.

Rogers, P.A.W., Lederman, F. and Taylor, N. (1998) Endometrial microvascular growth in normal and dysfunctional states. Hum. Reprod. Update, 4, 503-508.

Romanoff, A.L. (1960) The exraembryonic membranes. In The Avian Embryo: Structural and Functional Development. Mac Millan, New York, pp. 1039-1141.

Rous, P. and Murphy, J.B. (1911) Tumor implantations in the developing embryo. J. Am. Med. Assoc., 56, 741-742.

Ryan, I.P., Tseng, J.F., Schriock, E.D., Khorram, O.K., Landers, D.V. and Taylor, R.N. (1995) Interleukin-8 concentrations are elevated in peritoneal fluid of women with endometriosis. Fertil. Steril., 63, 929-932.

Sampson, J.A. (1927) Peritoneal endometriosis due to the menstrual dissemination of endometrial tissue into the peritoneal cavity. Am. J. Obstet. Gynecol., 14, 422-469. Sandberg, T., Casslén, B., Gustavsson, B. and Benraad, T.J. (1998) Human endothelial cell migration is stimulated by Urokinase Plasminogen Activator:Plasminogen Activator Inhibitor 1 complex released from endometrial stromal cells stimulated with Transforming Growth Factor $\beta 1$; possible mechanism for paracrine stimulation of endometrial angiogenesis. Biol. Reprod., 59, 759-767.

Scher, C.D., Haudenschild, C. and Klagsbrun, M. (1976) The chick chorioallantoic membrane as a model system for the study of tissue invasion by viral transformed cells. Cell, 8, 373-382.

Schmid-Schoenbein, G.W., Zweifach, B.W. and Kovalcheck, S. (1977) The application of stereological principles to morphometry of the microcirculation in different tissues. Microvasc. Res., 14, 303-317.

Schroyens, W., Schroyens, E. and Bielunas, J. (1989) Different invasion capacity of NBT II and MDCK in the chick embryo chorioallantois. Anticancer Res., 9, 1665-1668. Seto, F (1971) Allograft reactivity in chick embryos. J. Exp. Zool., 177, 343-352.

Sharkey, A.M., Day, k., McPherson, A., Malik, S., Smith, S.K. and Charnock-Jones, D.S. (2000) Vascular endothelial growth factor expression in human endometrium is regulated by hypoxia. J. Clin. Endocrinol. Metab., 85, 402-409.

Sharpe-Timms, K.L., Keisler, L.W., McIntush, E.W. and Keisler, D.H. (1998) Tissue inhibitor of metalloproteinase-1 concentrations are attenuated in peritoneal fluid and sera of women with endometriosis and restored in sera by gonadotropin-releasing hormone agonist therapy. Fertil. Steril., 69, 1128-1134. 
Shifren, J.L, Tseng, J.F., Zaloudek, C.J., Ryan, I.P., Meng, Y.G., Ferrara, N., Jaffe, R.B. and Taylor, R.N. (1996) Ovarian steroid regulation of vascular endothelial growth factor in the human endometrium: implications for angiogenesis during the menstrual cycle and in the pathogenesis of endometriosis. J. Clin. Endocrinol. Metab., 81, 31123118.

Singer, C.F, Marbaix, E., Lemoine, P., Courtoy, PJ. and Eeckhout, Y. (1999) Local cytokines induce differential expression of matrix metalloproteinases but not their tissue inhibitors in human endometrial fibroblasts. Eur. J. Biochem., 259, 40-45.

Smith, S.K. (1997) Angiogenesis. Semin. Reprod. Endocrinol., 15, $221-227$.

Smith, S.K. (1998) Angiogenesis, vascular endothelial growth factor and the endometrium. Hum. Reprod. Update, 4, 509-519.

Splawinski, J., Michna, M., Palczak, R., Konturek, S. and Splawinska, B. (1988) Angiogenesis: Quantitative assessment by the chick chorioallantoic membrane assay. Meth. Find. Exptl. Clin. Pharmacol., 10, 221-226.

Spuijbroek, M.D.E.H., Dunselman, G.A.J., Menheere, P.P.C.A. and Evers, J.L.H. (1992) Early endometriosis invades the extracellular matrix. Fertil. Steril., 58, 929933.

Starzinski-Powitz, A., Gaetje, R., Zeitvogel, A., Kotzian, S., Handrow-Metzmacher, H., Herrmann, G., Fanning, E. and Baumann, R. (1998) Tracing cellular and molecular mechanisms involved in endometriosis. Hum. Reprod. Update, 4, 724-729.

Starzinski-Powitz, A., Handrow-Metzmacher, H. and Kotzian, S. (1999) The putative role of cell adhesion molecules in endometriosis: can we learn from tumour metastasis? Mol. Med. Today, 5, 304-309.

Stetler-Stevenson, W.G., Liotta, L.A. and Kleiner, D.E. (1993a) Extracellular matrix 6: Role of matrix metalloproteinases in tumor invasion and metastasis. FASEB J., 7. 1434-4441.

Stetler-Stevenson, W.G., Aznavoorian, S. and Liotta, L.A. (1993b) Tumor cell interactions with the extracellular matrix during invasion and metastasis. Annu. Rev. Cell Biol., 9, 541-573.

Strick, D.M., Waycaster, R.L., Montani, J., Gay, W.J. and Adair, T.H. (1991) Morphometric measurements of chorioallantoic membrane vascularity: effects of hypoxia and hyperoxia. Am. J. Physiol., 260, H1385-H1389.

Sunderkötter, C., Steinbrink, K., Goebeler, M., Bhardwaj, R. and Sorg, C. (1994) Macrophages and angiogenesis. J. Leukoc. Biol., 55, 410-22.

Taketani, Y., Kuo, T. and Mizuno, M. (1992) Comparison of cytokine levels and embryo toxicity in peritoneal fluid in infertile women with untreated or treated endometriosis. Am. J. Obstet. Gynecol., 167, 265-270.

Taylor, R.N., Ryan, I.P., Moore, E.S., Hornung, D., Shifren, J.L. and Tseng, J.F (1997) Angiogenesis and macrophage activation in endometriosis. Ann. N. Y. Acad. Sci., 828, 194-207.

36 Torry, D.S., Holt, V.J., Keenan, J.A., Harris,G., Caudle, M.R. and Torry, R.J. (1996) Vascular endothelial growth factor expression in cycling human endometrium. Fertil. Steril., 66, 72-80. 
Van der Linden, PJ.Q., de Goeij, A.F.P.M., Dunselman, G.A.J., Van der Linden, E.P.M., Ramaekers, EC.S. and Evers, J.L.H. (1994) Expression of integrins and E-cadherin in cells from menstrual effluent, endometrium, peritoneal fluid, peritoneum and endometriosis. Fertil. Steril., 61, 85-90.

Van der Linden, P.J.Q., Dunselman, G.A.J., de Goeij, A.F.P.M., Van der Linden, E.P.M., Evers, J.L.H. and Ramaekers, EC.S. (1995a) Epithelial cells in peritoneal fluid: of endometrial origin? Am. J. Obstet. Gynecol., 173, 566-570.

Van der Linden, P.J.Q., de Goeij, A.F.P.M., Dunselman, G.A.J., Erkens, H.W.H. and Evers, J.L.H. (1995b) Expression of cadherins and integrins in human endometrium throughout the menstrual cycle. Fertil. Steril., 63, 1210-1216.

Van der Linden, PJ.Q., de Goeij, A.FPM., Dunselman, G.A.J., Erkens, H.W.H. and Evers, J.L.H. (1996) Endometrial cell adhesion in an in vitro model using intact amniotic membranes. Fertil. Steril., 65, 76-80.

Voss, K., Jacob, W. and Roth, K. (1984) A new image analysis method for the quantification of neovascularization. Exp. Pathol., 26, 155-161.

Vu, M.T., Smith, C.F., Burger, P.C. and Klintworth, G.K. (1985) An evaluation of methods to quantitate the chick chorioallantoic membrane assay in angiogenesis. Lab. Invest., 53, 499-508.

Westermarck, J. and Kähäri, V. (1999) Regulation of matrix metalloproteinase expression in tumor invasion. FASEB J., 13, 781-792.

Wilting, J., Christ, B. and Bokeloh, M. (1991) A modified chorioallantoic membrane (CAM) assay for qualitative and quantitative study of growth factors, Anat. Embryol., $183,259-271$.

Wingfield, M., Macpherson, A., Healy, D.L and Rogers, P.A.W. (1995) Cell proliferation is increased in the endometrium of women with endometriosis. Fertil. Steril., 64 , 340-346.

Witz, C.A., Monotoya-Rodriguez, I.A. and Schenken, R.S. (1999) Whole explants of peritoneum and endometrium: a novel model of the early endometriosis lesion. Fertil. Steril., 71, 56-60.

Zwilling, E. (1959) A modified chorioallantoic grafting procedure. Transplan. Bull., 6, 115-116. 


\section{Chapter 2}

Aims of the study

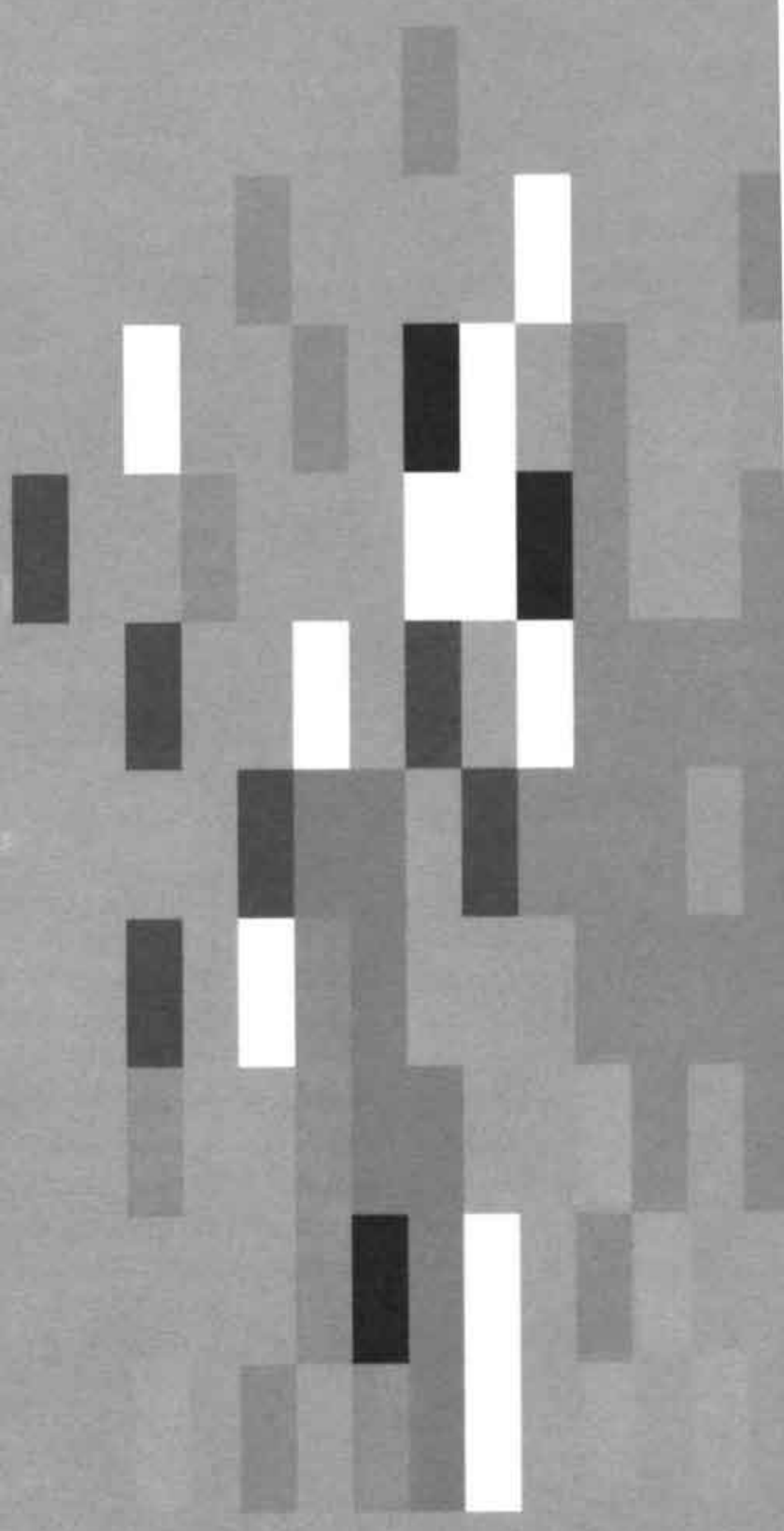


The implantation theory on the pathogenesis of endometriosis includes retrograde transportation of viable endometrial cells during menstruation, adhesion of these cells onto the peritoneum, with subsequent implantation and proliferation. Research has been focussed so far on identifying viable endometrial cells in peritoneal fluid and adhesive potential of endometrial cells to the peritoneal lining. It is still not clear which events occur between adhesion and clinical recognition of endometriotic lesions. We hypothesize that, following adhesion, endometrial cells invade and from that stage onwards induce angiogenesis for further outgrowth and development into an endometriotic lesion.

From cancer research we have learned that the chick embryo chorioallantoic membrane (CAM) model can be used to study the invasive and angiogenic potential of neoplastic cells. Besides, the CAM supplies blood vessels and connective tissue for the establishment and further outgrowth of tumor nodules. In the present study the chick embryo CAM model will be used to address several aims concerning the early events in the pathogenesis of endometriosis.

The first aim of the present study is to investigate the invasive potential of endometrial cells. The invasiveness of endometrial cells from different origins, e.g. an endometrial carcinoma cell line, antegradely shed menstrual effluent and cyclic endometrium (glands and stroma) is studied and described in chapter 3.

The second aim is to investigate whether, in analogy to tumor formation, endometriosis-like lesions can be formed in the CAM model after grafting of fresh human endometrial fragments. If such is the case, these lesions have to be characterized and the steps prior to lesion development studied. The experiments regarding this aim are presented in chapter 4 .

The third aim is to determine the angiogenic potential of endometrium tissue. First, an accurate, objective method of quantitating the angiogenic response had to be developed, which is described in chapter 5, before the angiogenic activity of endometrium in different stages of the menstrual cycle can be compared. This is discussed in chapter 6.

The fourth aim is to assess the angiogenic activity of peritoneal fluid from women with minimal to mild endometriosis. In an attempt to identify angiogenic factors in the peritoneal fluid, that might contribute to the development or maintenance of endometriosis, the relationship between the angiogenic activity and the concentration of some macrophage-derived angiogenic factors is investigated and dealt with in chapter 7.

Finally, the results of the studies described in this thesis are discussed in chapter 8. 


\section{Chapter 3}

\section{Invasive potential of human endometrial cells in the chick embryo chorioallantoic membrane model}

Jacques W.M. Maas, Patrick G. Groothuis, Gerard A.J. Dunselman,

Anton K.PM. de Goeij, Harry A.].Struijker Boudier, Johannes L.H. Evers

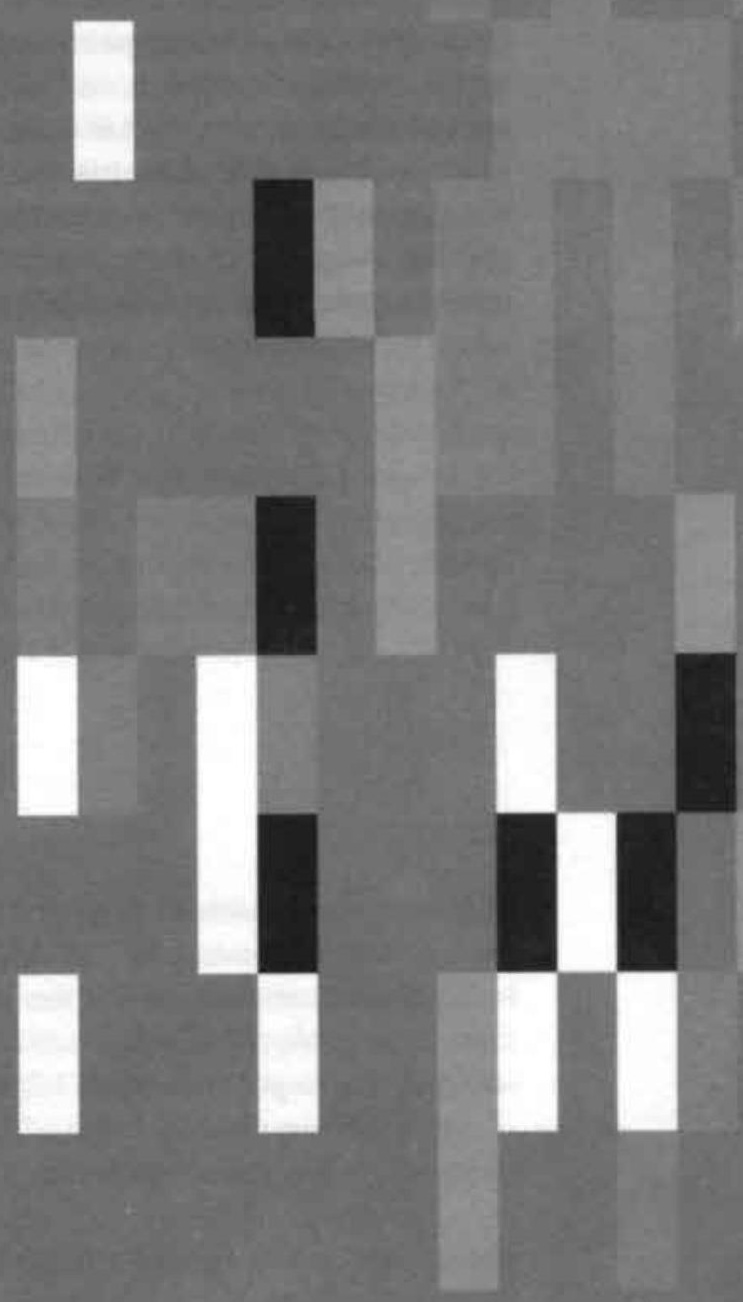




\begin{abstract}
Although the pathogenesis of endometriosis is still largely unknown, we hypothesized that after attachment to the peritoneal lining endometrial cells invade to develop into an endometriotic lesion. Suspensions were explanted onto the chick embryo chorioallantoic membrane (CAM) to study the invasive potential of endometrial cells. Suspensions of ECC-1 endometrium carcinoma cells were used to validate the model. Furthermore, suspensions containing menstrual effluent cells, or glandular structures and/or stromal cells obtained from endometrial biopsies were used. The explants including the surrounding CAM were excised at daily intervals up to 7 days after explantation and analyzed using immunohistochemistry.

ECC-1 cells were invasive and could be found in the mesenchymal layer at 5 days after explantation. This observation validated the CAM model to study invasion. Menstrual effluent cells were seen on top of the epithelial lining, but not in the mesenchymal layer of the CAM. Endometrial stromal cells were seen invading the epithelial lining within 1 day and were later consistently found in the mesenchymal layer of the CAM at a distance and separated from the explant. Only occasionally epithelial glandular structures, and never single epithelial cells, were seen within the epithelial layer or in contact with the mesenchymal layer.

In conclusion, both endometrial epithelial glandular structures and stromal cells, but not single epithelial or shed menstrual cells, are invasive in the CAM model. We suggest that the presence of a sufficiently large number of viable intact glandular structures surrounded by stromal cells in the peritoneal cavity is required for the development of endometriosis.
\end{abstract}




\section{Introduction}

Endometriosis is the presence of functional endometrial tissue in ectopic locations outside the uterine cavity. The transplantation or implantation theory on the pathogenesis of endometriosis as firstly described by Sampson (1927) presumes retrograde shedding of viable endometrial cells during menstruation and their subsequent implantation and proliferation. Implantation requires attachment and invasion of cells. In a collagen gel invasion assay to assess invasive potential of endometrial cells, only endometrial stromal cells or fibroblasts were shown to be invasive (Gaetje et al., 1997). In contrast, endometrial epithelial cells were not invasive in this in vitro assay. However, endometriotic lesions consist of both stromal cells and epithelial glands. Therefore, we hypothesize that the invasive potential of stromal as well as epithelial cells is a prerequisite for the development of peritoneal endometriosis.

The chick embryo chorioallantoic membrane (CAM) invasion model has been used for studying the ability of different, mostly neoplastic, types of cells to cross the CAM epithelial lining and invade the mesenchymal layer (Sher et al., 1976). In a related study (Maas et al., 2001), we have grafted endometrial fragments of $1.5 \times 2 \mathrm{~mm}$, obtained from endometrium at different phases of the menstrual cycle onto the CAM. Three days after grafting, we observed endometriosis-like lesions, containing human endometrial glands and stromal cells, in the mesenchymal layer of the CAM. From observations at regular time intervals, it appeared that these lesions resulted from the invasion of endometrial epithelial structures and stromal cells. In the present study we used suspensions of ECC-1 cells, an established epithelial cell line derived from an adenocarcinoma of human endometrial origin, to investigate the feasibility of the CAM model and the methods, which were applied to study invasion of endometrial cells. Ideally, retrogradely shed menstrual endometrial tissue should be used to learn more about the invasive step in the early pathogenesis of endometriosis. However, for practical reasons this tissue is hard to obtain in sufficient amounts. Therefore, we investigated the invasiveness of antegradely shed menstrual effluent cells and of endometrial glandular structures and stromal cells isolated from proliferative and secretory endometrial biopsies in the in vivo CAM invasion assay.

\section{Material and methods}

\section{Tissue}

ECC-1 cells were cultured in phenol red-free Dulbecco's modified Eagle's medium (DMEM)/Ham's F12 (Life Technologies BV, Breda, The Netherlands) supplemented with $5 \%$ dextran-coated charcoal stripped fetal calf serum, L-glutamine, $100 \mathrm{U} / \mathrm{ml}$ penicillin and $100 \mathrm{~g} / \mathrm{mL}$ streptomycin and Gibco Media Supplement A (Life Technologies). After reaching confluency, the ECC-1 cells were scraped off mechanically with a rubber policeman, centrifuged and the pellet was resuspended in medium. Cell suspensions from three different ECC-1 cell cultures were used for the experiments,

Female volunteers $(n=6)$ collected menstrual fluid with the use of a menstrual cup 
(Koks et al., 1997) for 2 to 3 hours during the first, second or third day of their menstrual period. After collection, the menstrual effluent was transferred immediately to the laboratory in a sterile plastic tube. The effluent $(5-10 \mathrm{ml})$ was diluted with complete medium consisting of DMEM/Ham's F12 supplemented with $10 \%$ fetal calf serum, L-glutamine, penicillin, and streptomycin and mixed with a pasteur pipet until a homogeneous suspension was achieved. This suspension was layered on a Ficoll-Paque gradient (Sigma-Aldrich Chemie BV, Zwijndrecht, the Netherlands) and centrifuged at 2500 rpm for 5 minutes, to remove red blood cells. The interphase containing endometrial and inflammatory cells was collected and passed through a 30 $\mu \mathrm{l}$ polyamide filter (Stokvis \& Smits, IJmuiden, the Netherlands). The endometrial fragments resting on this filter were washed into complete medium, centrifuged and the pellet was resuspended.

Samples of endometrial tissue were collected on different days of the menstrual cycle using a Probet endometrial sampling device (Gynetics, Oisterwijk, Netherlands) from 7 patients with regular menstrual cycles undergoing laparoscopic surgery during fertility investigations. The endometrium was rinsed once in complete medium and subsequently minced into small pieces. The suspension was centrifuged, and the medium was replaced with medium containing $0.25 \%$ collagenase I (ICN Biomedicals BV, Zoetermeer, the Netherlands). The tissue was digested for 30-45 minutes at $37^{\circ} \mathrm{C}$ and subsequently filtered through a $400-\mu \mathrm{m}$ stainless-steel sieve (Sigma-Aldrich Chemie BV), a 100- $\mu$ m nylon filter (Micronic, Lelystad, the Netherlands), and a 30- $\mu$ m polyamide filter (Stokvis \& Smits). The endometrial fragments, consisting of epithelial glandular structures and associated stromal cells were retained from the 100 - and 30 - $\mu \mathrm{m}$ filters. The cells in the filtrate were pelleted and the red blood cells were removed using a Ficoll-Paque gradient (Sigma-Aldrich Chemie $\mathrm{BV}$ ), in order to obtain a stromal cell fraction. The endometrial fragments were subjected to an additional digestion with $0.25 \%$ collagenase for 1.5 hours and filtered again through a $30-\mu \mathrm{m}$ filter to remove the dissociated stromal cells. Both this fraction of purified glandular structures and the stromal cell fraction were centrifuged and the pellet was resuspended in complete medium. Due to these manipulations, the glandular fraction has become a mixture of both epithelial glandular structures and single epithelial cells. In the experiments these stromal cell and glandular fractions were used combined as well as separately.

The use of human tissue for this study was approved by the institutional review board of the Maastricht university hospital and all women participating in this study signed a written informed consent.

\section{Chick embryo chorioallantoic membrane (CAM) model}

Fertile eggs of Lohman-selected White Leghorns were incubated for 3 days at $37^{\circ} \mathrm{C}$, $55 \%$ relative air humidity, while being rotated hourly. At day 3 of incubation, a rec44 tangular window $(1 \mathrm{~cm} \times 1.5 \mathrm{~cm})$ was made in the eggshell. Two milliliters of albumen were withdrawn, using a $21 \mathrm{G}$ needle, through the large blunt edge of the egg. The window was covered with Scotch tape to prevent dehydration. The eggs were placed back in the incubator without rotation until day 10 of incubation. 
The CAM is an impenetrable barrier to invasive cells unless it has first been traumatized by removing the upper peridermal part of the double epithelial layer, leaving the basal cell layer intact. Therefore, just before explantation a small portion of the CAM was gently traumatized by laying a 1-cm-wide strip of sterile ether-extracted lens tissue onto the surface of the epithelium and then removing it immediately (Armstrong et al., 1982; Maas et al., 2001). Subsequently, 25 - $40 \mu \mathrm{l}$ of the cell suspensions was explanted onto the CAM. Following the explantation, the window was covered again and the egg placed back in the incubator. At the end of the experiment the explant including the surrounding CAM was excised, fixed in $3.7 \%$ buffered formaldehyde and embedded in paraffin. If sufficient tissue was available, experiments were ended at 24 hour intervals up to 7 days, otherwise at 4 days after explantation. Parallel series of paraffin sections $(4 \mu \mathrm{m})$ were cut throughout the site of explantation and either stained with hematoxylin and eosin (HE) for histological evaluation or stored for immunohistochemical analysis.

\section{Immunohistochemistry}

Paraffin-embedded sections were deparaffinized and rehydrated. Endogenous peroxidase activity was blocked by incubation with $0.3 \%$ hydrogen peroxide in methanol for $20 \mathrm{~min}$. The sections were rinsed in PBS and subsequently digested in $0.1 \%$ pepsin in $0.1 \mathrm{~N} \mathrm{HCl}$ for $30 \mathrm{~min}$. After rinsing again in PBS, sections were incubated overnight at $4^{\circ} \mathrm{C}$ with a 1:100 dilution of the primary mouse monoclonal antibody against vimentin (Organon Teknika, Boxtel, Netherlands) or pan-cytokeratin (Clone MNF 116, DAKO, Glostrup, Denmark). After a PBS rinse, sections were exposed to biotinylated rabbit anti-mouse secondary antibody for one hour, rinsed and further exposed to avidin-biotinylated peroxidase complex for $30 \mathrm{~min}$. Antibody binding was visualized using 3'-3-diaminobenzidine yielding a brown reaction. Sections were washed and counterstained with diluted hematoxylin, washed, dehydrated and mounted for light microscopy.

\section{Results}

ECC-1 cell suspensions from three different cell cultures were explanted on 18 CAMs. As from day 3 direct contact of the ECC-1 cells with the mesenchymal layer of the CAM was visible. These areas of direct contact alternated with islands of chorionic epithelium (Figure 1A). At day 5 and day 6 clusters of ECC-1 cells were found in the mesenchymal layer of the CAM. These invading cells were cytokeratin-positive (Figure 1B).

Suspensions of menstrual effluent cells, collected from 6 women, were explanted onto 65 CAMs. In spite of extensive observations both at regular time intervals up to 7 days and in series of parallel sections throughout the site of explantation, in none of these CAMs invasion was seen. The menstrual cells were invariably seen on top of the epithelial lining. The thickened chorionic epithelium remained intact and menstrual effluent cells could not be found within this epithelial lining or in the mesenchymal layer (Figure 2). 

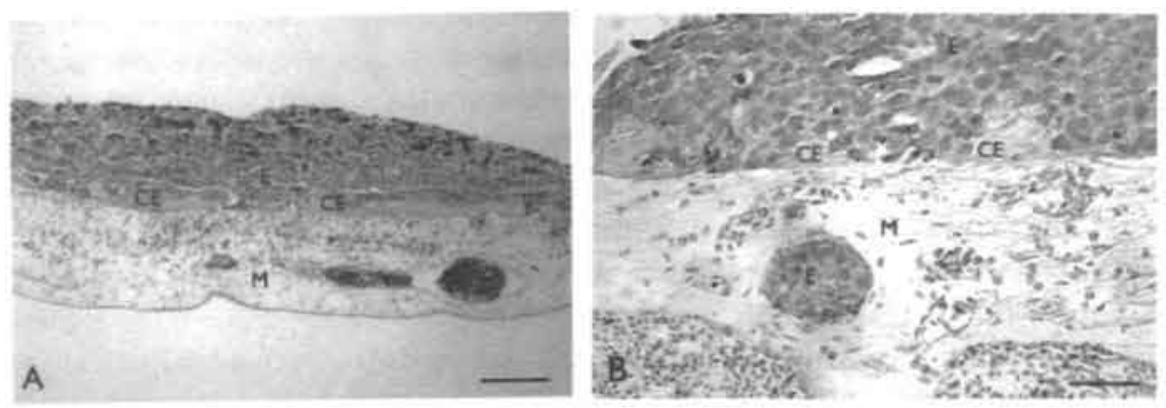

Figure 1 (A) Three days after grafting: areas of direct contact of the ECC-1 cells (E) with the mesenchymal layer $(\mathrm{M})$ alternate with islands of chorionic epithelium (CE) of the CAM (hematoxylin and eosin; Bar = 115 $\mu \mathrm{m}$ ). (B) Five days after grafting: clusters of cytokeratin- positive ECC-1 cells (E) were found in the mesenchymal layer $(\mathrm{M})$ of the CAM (cytokeratin; Bar $=40 \mu \mathrm{m})$.

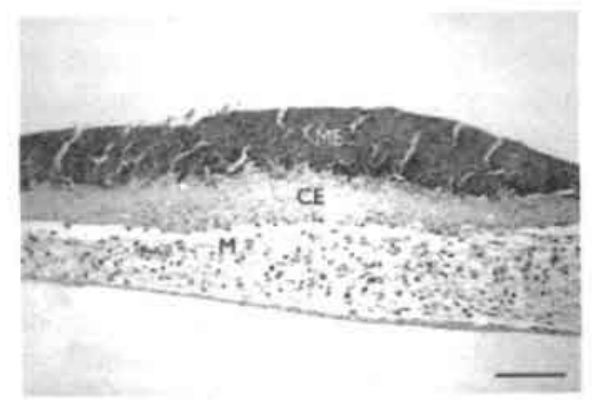

Figure 2 Four days after grafting, menstrual effluent cells (ME) are found on top of the intact thickened chorionic epithelial lining (CE) of the CAM. M, mesenchymal layer (hematoxylin and eosin; $B a r=80 \mu \mathrm{m}$ ).

From five women endometrial tissue was biopsied during the proliferative phase, from two women during the secretory phase. Suspensions containing stromal cells and/or glandular structures were explanted on 39 CAMs. Staining showed cytokeratin-positive as well as vimentin-positive cells in the fraction of purified glandular structures, whereas cytokeratin-positive cells were not found in the stromal cell fraction. Endometrial cells from 5 out of 7 women invaded the epithelial lining and endometrial stromal cells were found in the mesenchymal layer of the CAM at a distance and separated from the explant. After 24 hours, cytokeratin-positive epithelial glandular structures as well as clusters of vimentin-positive stromal cells were seen in the thickened chorionic epithelium. They were sometimes found in direct contact with the mesenchymal layer of the CAM (Figure 3A, 3B). After four days, vimentin-positive cells invaded the mesenchymal layer through an opening in the epithelial lining (Figure 3C). In addition, clusters of vimentin-positive cells could be found in the mesenchymal layer. These clusters were vascularized by CAM vessels, which contained nucleated chick erythrocytes (Figure 3D). 

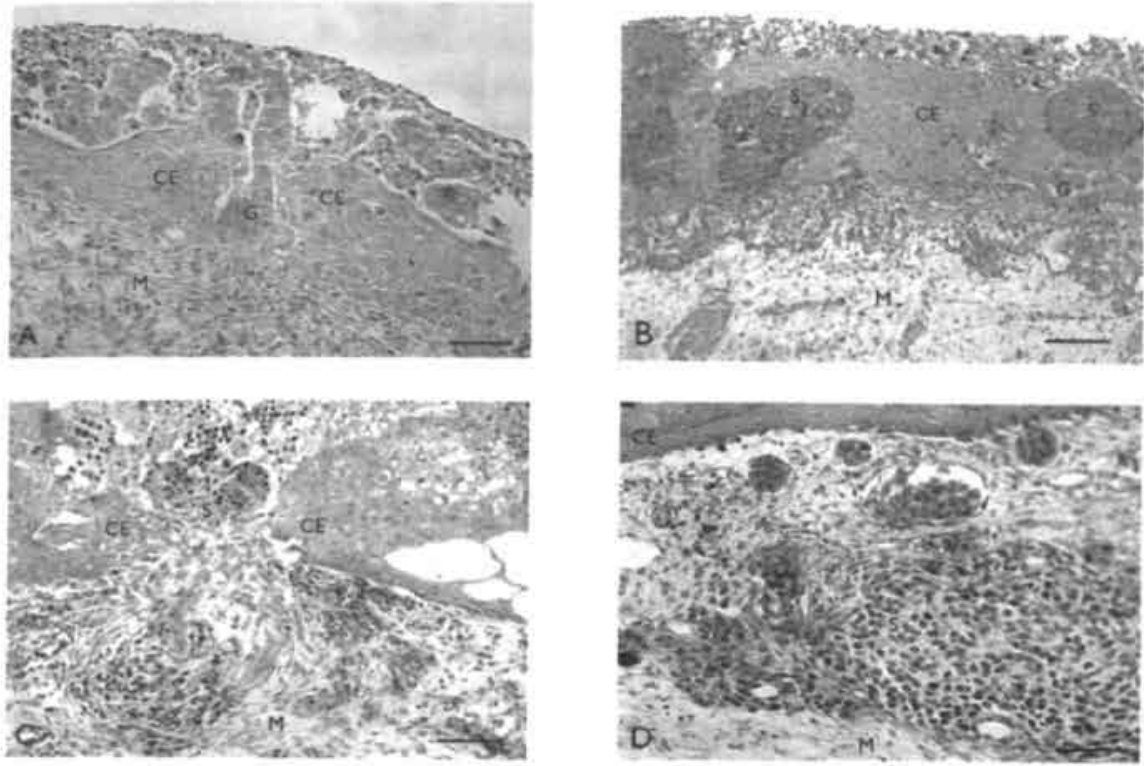

Figure 3 Twenty-four hours after grafting: (A) endometrial glandular structure invades the epithelial lining and is in contact with the mesenchymal layer (hematoxylin and eosin (HE); $B a r=40 \mu \mathrm{m}$ ), (B) clusters of stromal cells and glandular structures are found within the epithelial lining and in direct contact with the mesenchymal layer (vimentin; Bar $=83 \mu \mathrm{m}$ ). Four days after grafting: $(C)$ invasion of endometrial stromal cells through an opening in the epithelial lining into the mesenchymal layer (HE; Bar $=55 \mu \mathrm{m}$ ). (D) vascularization of cluster of endometrial stromal cells in the mesenchymal layer of CAM; CAM vessels contain nucleated chick erythrocytes (HE; $B a r=40 \mu \mathrm{m}$ ). CE, chorionic epithelium; $\mathrm{G}$, endometrial glandular structure; $M$, mesenchymal layer; $S$, stromal cells; $V$, CAM vessel.

\section{iscussion}

To test the validity of the CAM model and the methods which were applied, we explanted cell suspensions of ECC-1, an established epithelial cell line derived from an adenocarcinoma of human endometrial origin, onto the CAM. After 5 days, clusters of cytokeratin-positive ECC-1 cells could be found inside the mesenchymal layer of the CAM. Obviously, when endometrial cells do have invasive potential, invasion into the CAM can be observed after explantation of cell suspensions. This supports the validity of this model in our hands to study the invasion of endometrial cells. Ideally, retrogradely shed menstrual endometrium should be used to study the role of invasion in the early pathogenesis of endometriosis. The presence of viable endometrial tissue in peritoneal fluid in the early follicular phase of the cycle of women with patent tubes has been demonstrated (Kruitwagen et al., 1991). This endometrial tissue is occasionally recognized as glandular structures, but in most cases as single cells (Van der Linden et al., 1995). However, this material is difficult to obtain in sufficiently large amounts for the use as in our experiments. Therefore, in the present study, we used endometrial tissue isolated from antegradely shed menstrual effluent. 
This tissue also contains single cells, clusters of cells and glandular structures with attached stromal cells (Koks et al., 1997). It has been demonstrated that these endometrial cells adhere easily to the basement membrane and extracellular matrix of amnion and peritoneum (Koks et al., 1999). Furthermore, these cells express several matrix metalloproteinases, enzymes that degrade matrix components and therefore are potentially involved in invasion (Koks et al., 2000). In the present study, invasion was not observed when we explanted cell suspensions of antegradely shed menstrual effluent onto the CAM. An explanation for the inability of these cells to invade the CAM might be that the cells are not viable enough as compared to the retrogradely shed menstrual cells that are exposed to peritoneal environmental factors, such as hormones and growth factors. Alternatively, the structural architecture of the antegradely shed menstrual tissue may differ from the endometrial tissue in the peritoneal fluid. In an earlier study we could demonstrate that after 5 days of culture of cells obtained from antegradely shed menstrual effluent, vimentin- and cytokeratin-positive cells were identified in 10 out of 17 cases. This proved the viability of menstrual effluent cells (Koks et al. 1997). However, a substantial part of the antegradely shed menstrual effluent was apparently necrotic, which might be an explanation for the inability of the menstrual cells in our study to invade the CAM. Therefore, we prepared suspensions of stromal and epithelial fractions from more viable cyclic endometrial tissue, which was obtained with the use of a Probet sampling device. The stromal cells were invasive and were able to survive by induction of angiogenesis. This was demonstrated by the finding of clusters of human endometrial stromal cells within the moenendeymal lagos of dic cans, which were vascularized by chick embryo CAM vessels. We reported previously that human endometrium contained factors, which induced angiogenesis in this model (Maas et al., 1999). Furthermore, we did not observe invasion of single cytokeratin-positive epithelial cells, only invasion of intact epithelial glandular structures surrounded by stromal cells was sporadically observed. It was not possible to obtain suspensions of glandular structures, containing only epithelial cells. Apparently, stromal cells are always associated with intact epithelial structures.

Earlier, an in vitro collagen invasion assay was used to assess the invasive potential of endometrial cells (Gaetje et al., 1997). In this in vitro assay only vimentin-positive cells were invasive and not epithelial cells, which is in agreement with the present findings using an in vivo assay. In contrast to our study, only single cells were used and therefore information on the invasive potential of intact epithelial glandular structures in vitro was not obtained. We observed that exactly these epithelial cells, as part of an intact glandular structure surrounded by stromal cells, were invasive in the in vivo CAM model. Therefore, the structural organization of the tissue is apparently an important factor in facilitating invasive behaviour.

In this study we have demonstrated that both endometrial stromal cells and epithe48 lial glandular structures, but not single epithelial or menstrual effluent cells, are invasive in the in vivo CAM invasion model. Normally, the endometrial tissue, which reaches the abdominal cavity, is modulated by factors in the peritoneal fluid, resulting in single cells rather than glandular structures (Van der Linden et al., 1995). 
Therefore, under these conditions the chance that invasion of epithelial glandular structures and stromal cells into the peritoneal lining occurs and peritoneal endometriotic lesions develop is small. We suggest that number, viability and structural integrity of endometrial glandular structures surrounded by stromal cells in the peritoneal cavity are important factors in the development of endometriosis.

\section{Acknowledgments}

The authors thank Lilian Kessels from the Department of Pharmacology for excellent technical assistance. 


\section{References}

Armstrong, P.B., Quigley, J.P. and Sidebottom, E. (1982) Transepithelial invasion and intramesenchymal infiltration of the chick embryo chorioallantois by tumor cell lines. Cancer Res., 42, 1826-1837.

Gaetje, R., Kotzian, S., Herrmann, G. et al. (1997) Nonmalignant epithelial cells, potentially invasive in human endometriosis, lack the tumor suppressor molecule Ecadherin. Am. J. Pathol., 150, 461-467.

Koks, C.A.M., Dunselman, G.A.J., de Goeij, A.F.P.M. et al. (1997) Evaluation of a menstrual cup to collect shed endometrium for in vitro studies. Fertil. Steril., 68,560-564. Koks, C.A.M., Groothuis, P.G., Dunselman, G.A.J. et al. (1999) Adhesion of shed menstrual tissue in an in-vitro model using amnion and peritoneum: a light and electron microscopic study. Hum. Reprod., 14, 816-822.

Koks, C.A., Groothuis, P.G., Slaats, P. et al. (2000) Matrix metalloproteinases and their tissue inhibitors in antegradely shed menstruum and peritoneal fluid. Fertil. Steril., 73, 604-612.

Kruitwagen, R.F.P.M., Poels,L.G., Willemsen,W.N.P., et al. (1991) Endometrial epithelial cells in peritoneal fluid during the early follicular phase. Fertil. Steril., 55, 297-303. Maas, J.W.M., Le Noble, F.A.C., Dunselman, G.A.J. et al. (1999) The chick embryo chorioallantoic membrane as a model to investigate the angiogenic properties of human endometrium. Gynecol. Obstet. Invest., 48, 108-112.

Maas, J.W.M., Groothuis, P.G., Dunselman, G.A.J. et al. (2001) Development of endometriosis-like lesions after transplantation of human endometrial fragments onto the chick embryo chorioallantoic membrane. Hum. Reprod., 16, 627-631.

Sampson, J.A. (1927) Peritoneal endometriosis due to the menstrual dissemination of endometrial tissue into the peritoneal cavity. Am. J. Obstet. Gynecol., 14, 422-469. Scher, C.D., Haudenschild, C. and Klagsbrun, M. (1976) The chick chorioallantoic membrane as a model system for the study of tissue invasion by viral transformed cells. Cell, 8, 373-382.

Van der Linden, P.J.Q., Dunselman, G.A.J., de Goeij, A.F.P.M., et al. (1995) Epithelial cells in peritoneal fluid: of endometrial origin? Am. J. Obstet. Gynecol., 173, 566-570. 


\section{Chapter 4}

Development of endometriosis-like lesions after transplantation of human endometrial fragments onto the chick embryo chorioallantoic membrane

Jacques W.M. Maas, Patrick G. Groothuis, Gerard A.J. Dunselman, Anton F.P. M. de Goeij, Harry A.J. Struijker Boudier, Johannes L.H. Evers

Human Reproduction, 16, 627-631.

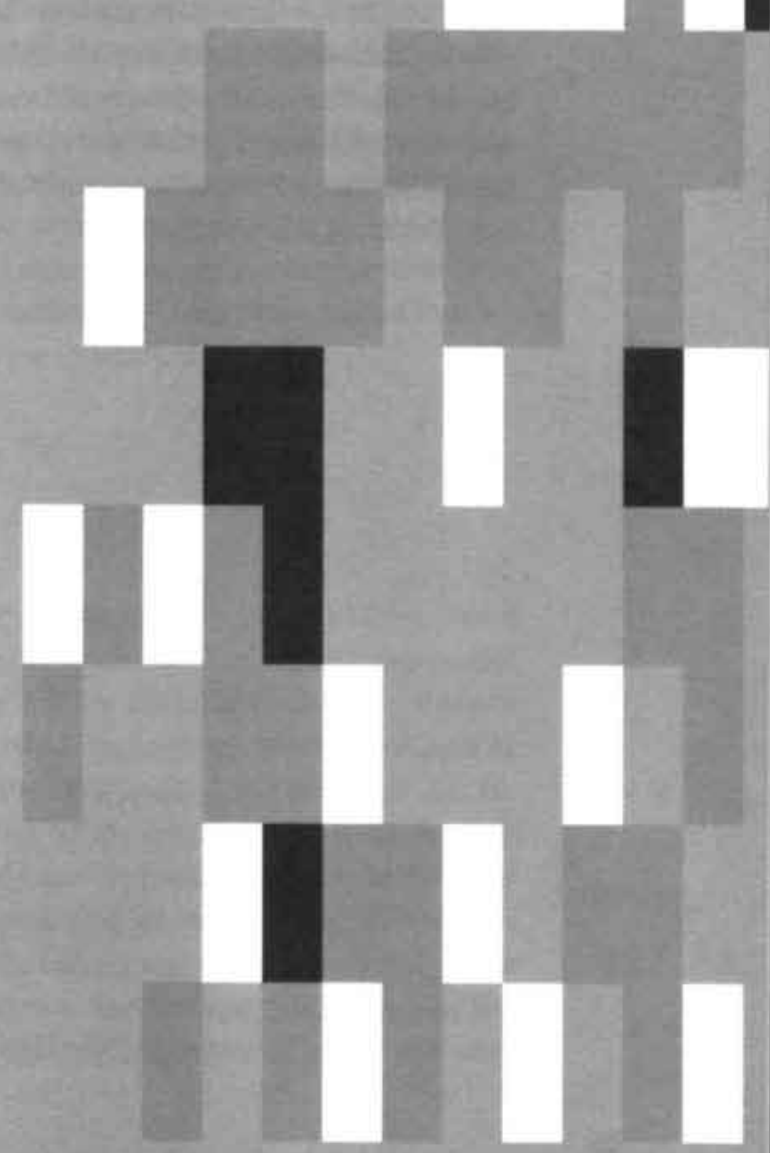


tangular window $(1 \mathrm{~cm} \times 1.5 \mathrm{~cm}$ ) was made in the eggshell. Two milliliters of albumen were withdrawn, using a $21 \mathrm{G}$ needle, through the large blunt edge of the egg. The window was covered with Scotch tape to prevent dehydration. The eggs were replaced in the incubator without rotation until day 10 of incubation. The CAM is an impenetrable barrier to invasive cells unless it has first been traumatized by removing the upper peridermal part of the double epithelial layer, leaving the basal cell layer intact. Therefore, just before explantation a small portion of the CAM was gently traumatized by laying a 1-cm-wide strip of sterile ether-extracted lens tissue onto the surface of the epithelium and then removing it immediately (Armstrong et al., 1982). Subsequently, the dissected fragments were explanted onto the CAM within $2 \mathrm{~h}$ after obtaining the tissue. On each CAM only one fragment was layered. Following the explantation the window was covered again and the egg was placed back in the incubator. At 24, 48 or 72 hours after explantation the graft including the surrounding CAM was excised, fixed in $3.7 \%$ buffered formalin and embedded in paraffin. Paraffin sections $(4 \mu \mathrm{m})$ were cut and either stained with hematoxylin and eosin (HE) for histological evaluation or stored for later immunohistochemical and in situ hybridization analysis.

\section{Immunohistochemistry}

Paraffin sections were deparaffinized by incubation with xylene for $2 \times 5$ min and rehydrated in a graded alcohol series. Endogenous peroxidase activity was blocked by incubation with $0.3 \%$ hydrogen peroxide in methanol for $20 \mathrm{~min}$. The sections were rinsed in phosphate-buffered saline (PBS) and subsequently digested in $0.1 \%$ pepsin in $0.1 \mathrm{~N} \mathrm{HCl}$ for $30 \mathrm{~min}$. After rinsing again in PBS, sections were incubated overnight at $4^{\circ} \mathrm{C}$ with a 1:100 dilution of the primary antibody to vimentin (Organon Teknika, Boxtel, Netherlands) or to pan-cytokeratin (Clone MNF 116, DAKO, Glostrup, Denmark). After a PBS rinse, sections were exposed to biotinylated rabbit anti-mouse secondary antibody for one hour, rinsed and further exposed to avidin-biotinylated peroxidase complex for $30 \mathrm{~min}$. Antibody binding was visualized using 3'- 3 -diaminobenzidine. Sections were washed and counterstained with hematoxylin, washed, dehydrated and mounted for light microscopy.

\section{In situ hybridization}

The in situ hybridization procedure was performed as described in detail by Jansen and coworkers (1998). In short, sections were pretreated with $1 \mathrm{M}$ sodium thiocyanate at $80^{\circ} \mathrm{C}$ for $10 \mathrm{~min}$ and digested with $4 \mathrm{mg} / \mathrm{ml}$ pepsin in $0.2 \mathrm{~N} \mathrm{HCl}$ at $37^{\circ} \mathrm{C}$. The digoxygenin-labeled DNA probe, used for the in situ hybridization analysis, hybridizes to the (peri) centromeric regions of human chromosome 1 (pUCl.77, 1.77kb), but not to chicken chromosome 1 . The probe was dissolved in hybridization buffer, containing $60 \%$ formamide, $2 x S S C \mathrm{pH} 7.0,10 \%$ dextran sulphate, $0.2 \mathrm{mg} / \mathrm{ml}$ herring sperm DNA and yeast tRNA as carrier DNA and RNA, respectively. The final probe concentration was $0.4 \mathrm{ng} / \mathrm{ml}$. Ten microliters of hybridization mixture were added to the slides under a coverslip. Samples were then denaturated in a moist chamber at $75^{\circ} \mathrm{C}$ for $3 \mathrm{~min}$. Hybridization was allowed overnight at $37^{\circ} \mathrm{C}$. Samples were washed twice 
for $5 \mathrm{~min}$ in $2 \mathrm{xSSC} / 0.05 \%$ Tween 20 buffer $\mathrm{pH} 7.0$, at $42^{\circ} \mathrm{C}$, twice for $5 \mathrm{~min}$ in $0.01 \times S S C / 0.05 \%$ Tween 20 buffer $\mathrm{pH} 7.0$, at $60^{\circ} \mathrm{C}$, and once in $4 \times S S C / 0.05 \%$ Tween 20 buffer for $5 \mathrm{~min}$ at room temperature. The digoxygenin-labeled probe was detected in subsequent incubations with mouse anti-digoxine IgG (1:2000; Sigma, St Louis, MO, USA), horse radish peroxidase conjugated rabbit anti-mouse IgG (1:80; DAKO), and finally with TRITC-labeled tyramide, diluted 1:100 in PBS/imidazol containing $0.001 \%$ hydrogen peroxide. Nuclei were counterstained with 4-,6-diaminodino-2phenylindole (DAPI; Sigma; $1.25 \mathrm{ng} / \mathrm{ml}$ ), diluted in glycerol containing 2.3\% 1,4-diazobicyclo-(2.2.2)-octane (DABCO; Sigma). Nuclei were examined with a Leica microscope (Leica, Cambridge, UK) equipped for fluorescence with DAPI and rhodamine filter sets.

\section{Scanning Electron Microscopy}

Membranes were processed for electron microscopic analysis to check if the basal epithelial cell layer was still intact after removing the peridermal layer. Membranes were fixed in $2.5 \%$ glutaraldehyde in phosphate buffer ( $\mathrm{pH} 7.4$ ). The membranes were dehydrated in alcohol. The samples were critical-point-dried, sputtered with gold, and studied under a Philips 505 scanning electron microscope (Philips, Eindhoven, The Netherlands).

\section{Results}

The CAM consists of an outer chorionic epithelium (CE) of ectodermal cells, a mesodermal layer consisting of loose connective tissue and blood vessels and an inner allantoic epithelium (AE) of endodermal cells. The CE is a continuous double layer of cells with a superficial sheet of flat peridermal cells and a basal cell layer, which is an impenetrable barrier to invasive cells. We, therefore, removed the upper peridermal part, leaving the basal epithelial cell layer intact (Figure 1). Endometrial fragments, consisting of glands and stroma, were grafted onto the CAM (Figure 2). Already after 24 hours, endometrial stroma and occasionally intact glands were found in direct contact with the mesenchymal layer of the CAM (Figure 3A, 3B). After 48 hours both stromal cells and intact epithelial glands surrounded by stromal cells invaded across

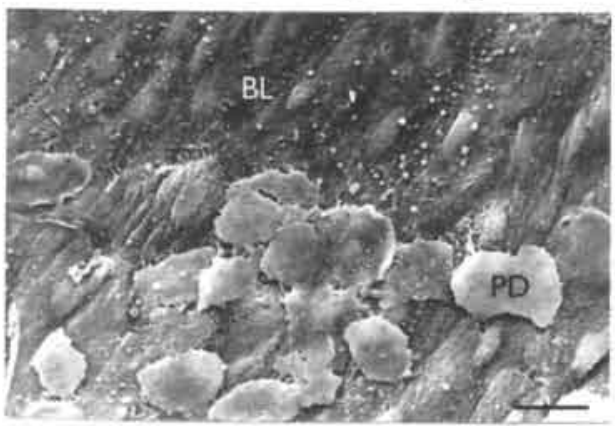

Figure 1 Scanning electron micrograph of the partly traumatized chorionic epithelium of the CAM: the superficial sheet of flat peridermal cells (PD) has been removed exposing the basal epithelial cell layer (BL) $(\mathrm{Bar}=11 \mu \mathrm{m})$. 


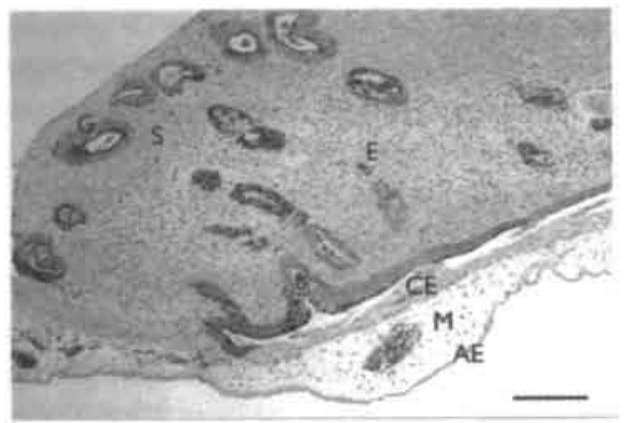

Figure 2 Light micrograph of a cross section of the CAM containing an endometrial fragment (E) of cycle day 7 , that consists of glands (G) and stromal cells (S). CE, chorionic epithelium; M, mesenchymal layer; AE, allantoic epithelium (cytokeratin: $B a r=160 \mu \mathrm{m}$ ).

the epithelial layer into the mesenchymal layer (Figure 3C, 3D). Invasion of single cytokeratin positive cells was not observed. We observed after three days of incubation, endometriosis-like lesions, which consisted of dilated glands and stromal cells in the mesenchymal layer at a distance from the original graft (Figure 3E). In each distant lesion we observed at least one dilated gland. The vital lesions appeared to receive their blood supply from CAM vessels, which contain nucleated chick erythrocytes. This is illustrated in figure $3 \mathrm{~F}$, which shows a branch from a CAM vessel penetrating the endometriosis-like lesion. Furthermore, cross-sections of CAM vessels can be seen inside the lesion.

Figure 4 presents the (immuno)histochemical and in situ hybridization analysis of the endometriosis-like lesions observed 72 hours after grafting. The centre of the lesions consists of vimentin positive cells (Figure 4B). Furthermore, intense staining of the gland-like structures with human pan-cytokeratin antibody was observed (Figure 4C). In both vimentin positive and cytokeratin positive cells ISH-signals were found for human chromosome 1 (Figure 4D); no signals were observed in the rest of the CAM.

Endometrial fragments were explanted onto 59 CAMs. By means of extensive observations both at regular time intervals and in series of parallel sections throughout the site of explantation, endometriosis-like lesions could be found after grafting of endometrium obtained from 9 out of 15 women. Although lesions could not be found after grafting of endometrial fragments at several CAMs from 6 women, we observed invasion of endometrial cells obtained from 2 of these women into the mesenchymal layer. Therefore, endometrial fragments from only 4 (cycle day 5, 10, 12 and 22) out of 15 women showed neither invasion nor formation of a distant lesion after grafting onto the CAM. During laparoscopy, some endometriotic lesions were observed in 3 patients. The endometrial cells obtained from these three patients were invasive in this CAM model, and endometriosis-like lesions were found after grafting of endometrium of two of these women. 

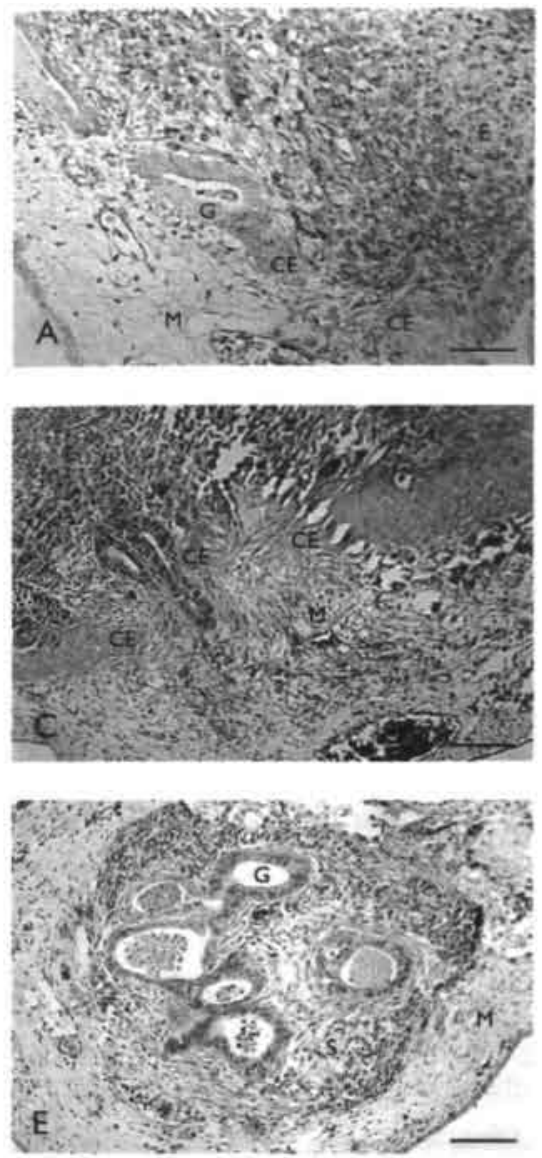
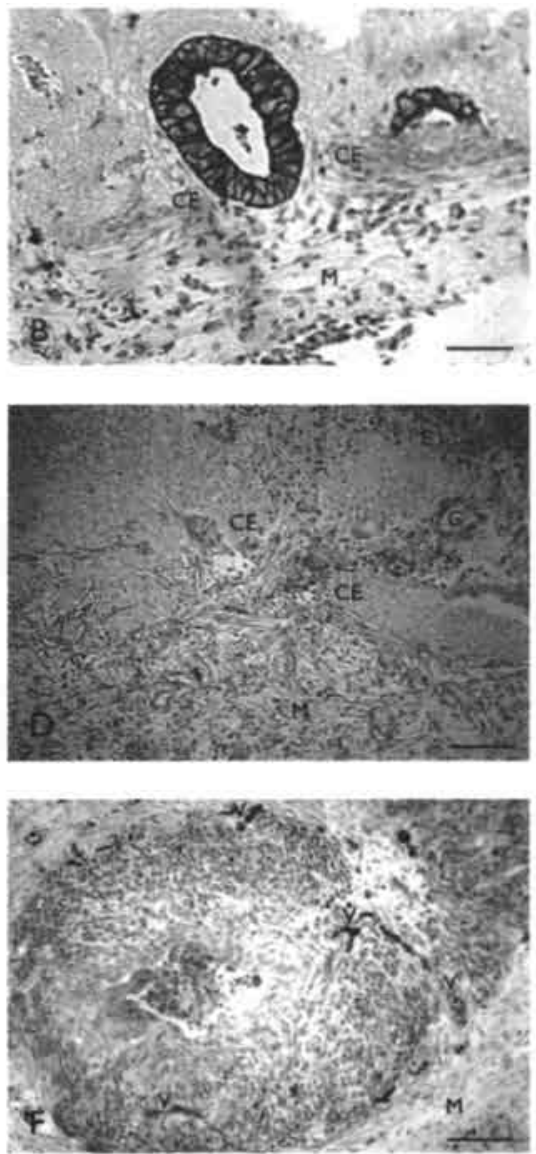

Figure 3 Development of endometriosis-like lesion after grafting of an endometrial fragment onto the CAM. (A) 24 hours after grafting: direct contact endometrial glands and stromal cells with mesenchymal layer (hematoxylin and eosin $(\mathrm{HE}) ; \mathrm{Bar}=55 \mu \mathrm{m}$ ). (B) Staining of endometrial gland, which is in direct contact with mesenchymal layer, with pan-cytokeratin antibody (Bar $=40 \mu \mathrm{m})$. (C) 48 hours after grafting: invasion of endometrial glands and stromal cells across the epithelial layer into the mesenchymal layer (HE; $\mathrm{Bar}=80 \mu \mathrm{m}$ ). (D) Invasion of vimentin positive stromal cells (vimentin; $\mathrm{Bar}=80 \mu \mathrm{m}$ ). (E) $72 \mathrm{hours}$ after grafting; lesion in mesenchymal layer of CAM, containing glands and stromal cells (HE; Bar $=80 \mu \mathrm{m}$ ). (F) Branch of CAM vessel, containing nucleated chick erythrocytes, penetrates the lesion and in the lesion $\mathrm{CAM}$ vessels can be observed $(\mathrm{HE} ; \mathrm{Bar}=80 \mu \mathrm{m})$. CE, chorionic epithelium: $\mathrm{E}$, endometrial fragment: $\mathrm{G}$, endometrial gland; $M$, mesenchymal layer, $S$, stromal cells; V, CAM vessel. 

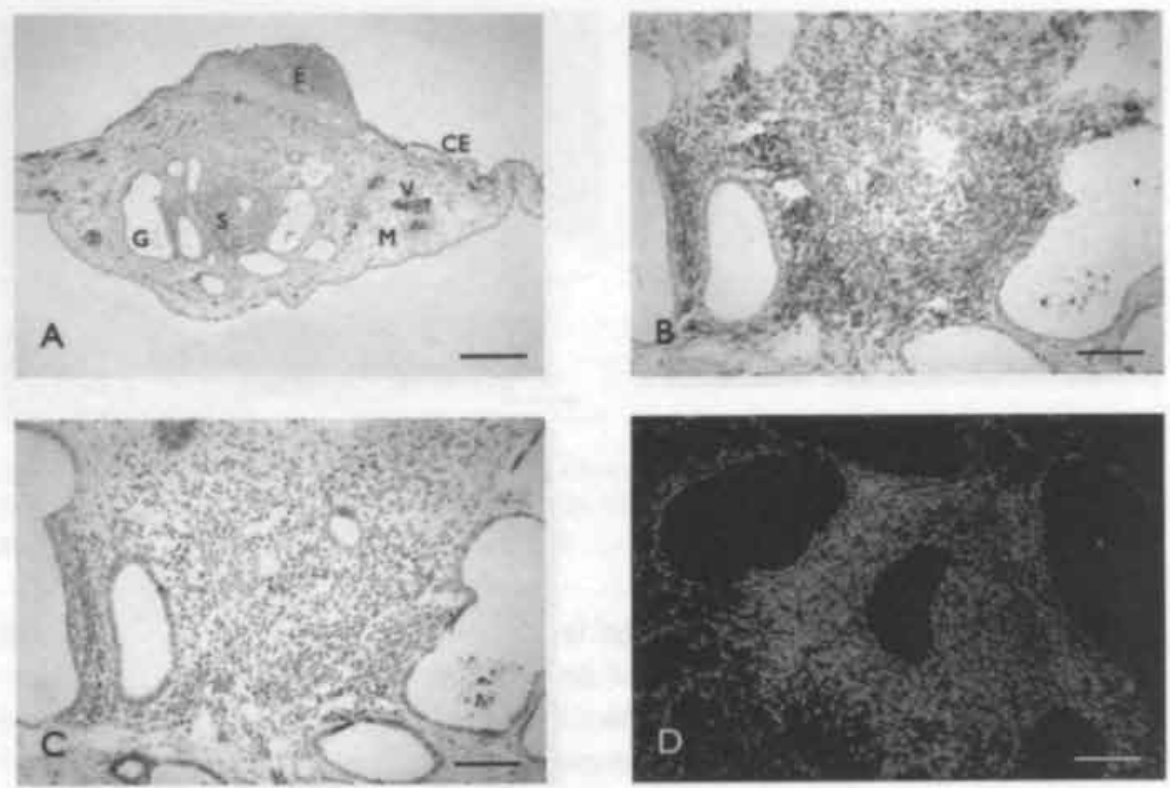

Figure 4 (A) Endometriosis-like lesion in mesenchymal layer (M) of the CAM at a distance from the original endometrial graft (E), containing dilated glands (G) and stromal cells (S). CE, chorionic epithelium; V, CAM vessel (hematoxylin and eosin: Bar $=275 \mu \mathrm{m}$ ). (B) Staining of stromal cells with vimentin antibody $($ Bar $=80 \mu \mathrm{m})$. (C) Staining of glandular epithelial cells with pan-cytokeratin antibody $(B a r=80 \mu \mathrm{m})$. (D) Fluorescence in situ hybridization using probe for human chromosome 1 (red): signal is visible in nuclei of both stromal and epithelial cells $(B a r=80 \mu \mathrm{m})$.

\section{Discussion}

The chick embryo CAM has been used to study tumor transplantation and invasion since the first description of successful transplantation of heterologous tumors to the CAM was published (Murphy, 1912). With the aid of scanning electron microscopy it became clear that the CAM is an impenetrable barrier to neoplastic cells unless it has first been traumatized by removing the upper peridermal part of the double layer of chorionic epithelium (McCormick et al., 1984). The basal cell layer of this epithelium is resistant to mechanical damage and can be used to distinguish invasive from noninvasive cells (Schroyens et al., 1989). Using this CAM model, we demonstrated in the present study that both endometrial stromal and epithelial cells are invasive. Invasion of single cytokeratin positive epithelial cells could not be observed, only invasion of intact endometrial glands has been seen. These invading glands were surrounded by vimentin positive cells, indicating that these cells were either endometrial stromal cells or fibroblasts. Using a collagen gel invasion assay to assess the invasive potential of endometrial cells, Gaetje and coworkers (1997) concluded that only vimentin positive cells were invasive in vitro and not epithelial cells. An explanation for the discrepancy between their findings and ours may be that in their study endometrial biopsies were digested and the cells were cultured. They plated single cells 
onto the collagen gels, excluding the possibility to study the invasive potential of intact fragments consisting of stroma and glands. It appears that for epithelial cells the mutual contact, leaving the glandular structure intact, as well as contact with surrounding stromal cells is a prerequisite for invasive potential.

Endometriosis-like lesions could be found in the mesenchymal layer already 72 hours after grafting of endometrial fragments onto the CAM. These lesions in the chick embryo CAM consist of both endometrial stromal and epithelial cells, as was demonstrated by the positive staining for vimentin and cytokeratin, respectively. In addition, some staining of CAM epithelium as well as some mesenchymal cells was seen occasionally. Therefore, we applied FISH-analysis using a probe specific for human chromosome 1 to make a positive distinction between chick embryo and human cells. We demonstrated clearly that the lesions in the chick embryo CAM are of human origin. Occasionally vessels, containing nucleated chick erythrocytes, could be observed in the lesions. Apparently, the CAM blood vessels branch and penetrate the endometriosis-like lesions.

Recently, Ohtake and coworkers (1999) concluded that endometriotic lesions arise through a process of metaplasia from ovarian surface epithelial cells. Their study was based on the induction theory, which has been introduced by Levander and Normann (1955) and further developed by Merrill (1966). According to this theory, the endometrial fragments should produce or release factors, which activate the chick embryo chorionic epithelium to form glandular structures in the mesenchymal layer. We demonstrated that the epithelial lining of the glands in the endometriosislike lesions is of human origin, which is not consistent with the induction theory.

We experienced that lesions and site of invasion could not always be found. This either means that we failed to obtain an appropriate section of the very small lesion or that the endometrial cells were not invasive. Also Leighton (1964) already described that his results varied depending on the tumor used and even in the same experiment, divergent results were sometimes observed.

Fragments used in this study may not be truly representative of the in vivo situation. Therefore, it may also be relevant to use endometrial tissue isolated from menstrual effluent or cell suspensions. Based on the findings of the present study, we hypothesize that presence of intact glandular structures with stromal components is required for the invasive potential of endometrial cells and the formation of endometriosislike lesions.

In conclusion, three days after grafting of endometrial fragments, endometriosis-like lesions, consisting of human endometrial glands and stromal cells, are detected in the mesenchymal layer of the CAM. These lesions result from the invasion of intact human epithelial structures surrounded by human endometrial stromal cells. 


\section{Acknowledgments}

The authors thank Lilian Kessels from the Department of Pharmacology for excellent technical assistance and Prof. dr. F. Ramaekers and Monique Ummelen from the Department of Molecular Cell Biology \& Genetics, Maastricht University for the hybridization procedure. 


\section{References}

Armstrong, P.B., Quigley, J.P. and Sidebottom, E. (1982) Transepithelial invasion and intramesenchymal infiltration of the chick embryo chorioallantois by tumor cell lines. Cancer Res., 42, 1826-1837.

Gaetje, R., Kotzian, S., Herrmann, G. et al. (1997) Nonmalignant epithelial cells, potentially invasive in human endometriosis, lack the tumor suppressor molecule Ecadherin. Am. J. Pathol., 150, 461-467.

Groothuis, P.G., Koks, C.A.M., de Goeij, A.F.P.M. et al. (1999) Adhesion of human endometrial fragments to peritoneum in vitro. Fertil. Steril., 71, 1119-1124.

Jansen, M.P.H.M., Hopman, A.H.N., Haesevoets, A.M. et al. (1998) Chromosome abnormalities in Hodgkin's disease are not restricted to Hodgkin/Reed-Sternberg cells. J. Pathol., 185, 145-152.

Koks, C.A.M., Groothuis, P.G., Dunselman, G.A.J. et al. (1999) Adhesion of shed menstrual tissue in an in-vitro model using amnion and peritoneum: a light and electron microscopic study. Hum. Reprod., 14, 816-822.

Kruitwagen, R.F.P.M., Poels,L.G., Willemsen, W.N.P., et al. (1991) Endometrial epithelial cells in peritoneal fluid during the early follicular phase. Fertil. Steril., 55, 297 303.

Leighton, J. (1964) Invasion and metastasis of heterologous tumors in the chick embryo. Progr. exp. Tumor Res., 4, 98-125.

Levander, G. and Normann, P. (1955) The pathogenesis of endometriosis. Acta Obstet. Gynecol. Scand., 34, 366-398.

McCormick, J.F., Nassauer, J., Bielunas, J. et al. (1984) Anatomy of the chick chorioallantoic membrane relevant to its use as a substrate in bioassay systems. Scan. Electron. Microsc., IV, 2023-2030.

Merrill, J.A. (1966) Endometrial induction of endometriosis across Millipore filters. Am. J. Obstet. Gynecol., 94, 780-790.

Murphy, J.B. (1912) Transplantability of malignant tumors to the embryos of foreign species. J. Amer. Med. Assoc., 59, 874-875.

Ohtake, H., Katabuchi, H., Matsuura, K. et al. (1999) A novel in vitro experimental model for ovarian endometriosis: the three-dimensional culture of human ovarian surface epithelial cells in collagen gels. Fertil. Steril., 71, 50-55.

Sampson, J.A. (1927) Peritoneal endometriosis due to the menstrual dissemination of endometrial tissue into the peritoneal cavity. Am. J. Obstet. Gynecol., 14, 422-469.

Scher, C.D., Haudenschild, C. and Klagsbrun, M. (1976) The chick chorioallantoic membrane as a model system for the study of tissue invasion by viral transformed cells. Cell, 8, 373-382.

Schroyens, W., Schroyens, E. and Bielunas, J. (1989) Different invasion capacity of NBTII and MDCK in the chick embryo chorioallantois. Anticancer Res., 9, 1665-1668. Van der Linden, P.J.Q., Dunselman, G.A.J., de Goeij, A.F.P.M. et al. (1995) Epithelial cells in peritoneal fluid: of endometrial origin? Am. J. Obstet. Gynecol., 173, 566-570. 


\section{Chapter 5}

\section{The chick embryo chorioallantoic membrane as a model to investigate the angiogenic properties of human endometrium}

Jacques W.M. Maas, Ferdinand A.C. Le Noble, Gerard A.J. Dunselman, Anton F.R.M. de Goeij, Harry A.J. Struijker Boudier, Johannes L.H. Evers

Gynecologic and Obstetric Investigation 1999, 48, 108-112

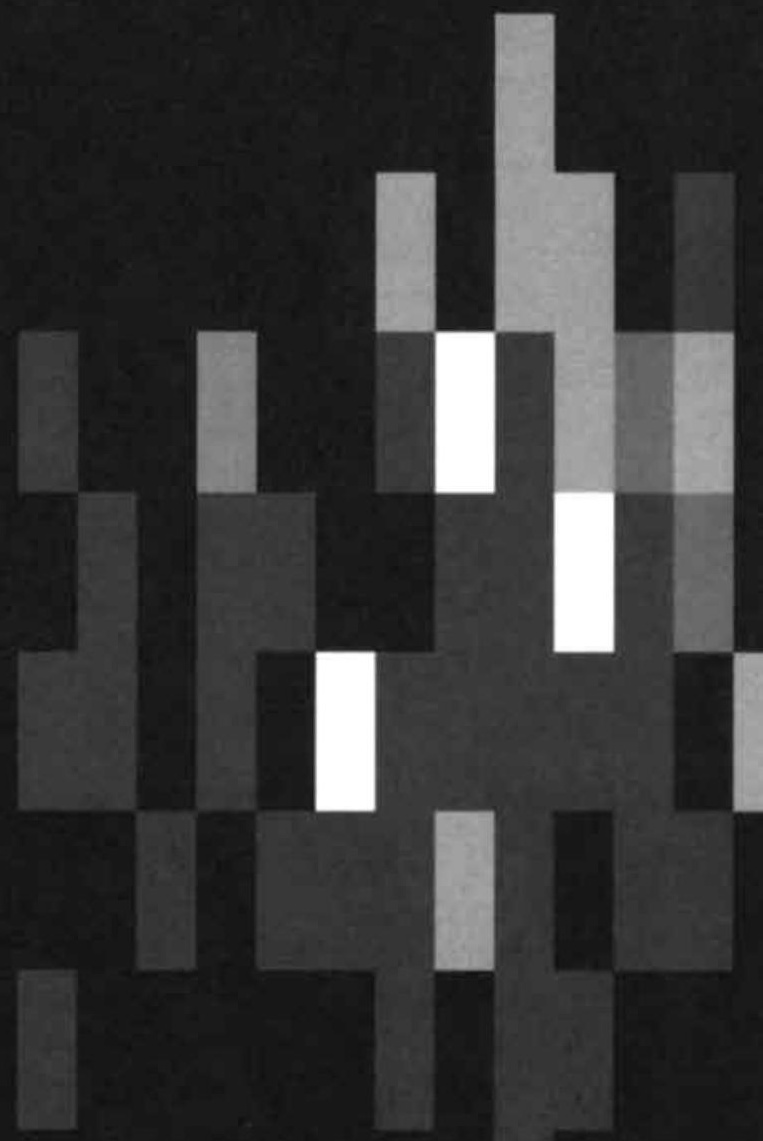




\begin{abstract}
The chick embryo chorioallantoic membrane (CAM) is an established in vivo angiogenesis assay. The aim of our study was to assess the angiogenic properties of endometrium and to quantitate the vascular response in an accurate way. Samples of proliferative endometrium $(n=17)$ and control mouse skin tissue $(n=8)$ were explanted onto the CAM at day 10 of incubation. Additional controls consisted of normal unmanipulated CAM $(n=12)$. Four days after grafting, photographs of the explant and the surrounding area were taken in ovo to measure the vascular density index (VDI). The VDI is a stereological estimate of vessel number and length, which was obtained by counting the intersections of vessels with a circular grid superimposed on a computerized image. Endometrium caused a significant increase in VDI as compared to both unmanipulated CAM ( $\mathrm{p}<0.001$ ) and skin tissue as a control $(\mathrm{p}<0.007)$. The intraobserver variability was $5.2 \%$. This study demonstrates that the CAM assay is a suitable model to assess the angiogenic properties of endometrium. Furthermore, it allows detailed quantitation of the vascular response in an objective and reproducible way. Our findings suggest the CAM to be a promising model to study the role of angiogenesis in both normal human endometrium and diseases involving the endometrium.
\end{abstract}




\section{Introduction}

Angiogenesis is the process of generating new capillary blood vessels (Folkman, 1985). In the adult, under physiological conditions, angiogenesis is rare, apart from the female reproductive system where angiogenesis occurs in the ripening follicle, the corpus luteum and the endometrium. Under these normal circumstances angiogenesis is self-limiting, in contrast to pathological angiogenesis, e.g. in cancer, proliferative diabetic retinopathy and peripheral vascular disease (Findlay, 1986; Klagsbrun and D'Amore, 1991; Gordon et al., 1995). In the female reproductive tract, defects in angiogenesis may contribute to a variety of disorders such as luteal phase defects, endometriosis, pregnancy loss, preeclampsia, and cancer (Gordon et al., 1995). Klauber and co-workers (1997) hypothesized that inhibitors of angiogenesis may be effective in treating pathologic reproductive disorders such as endometriosis.

Angiogenesis has been studied predominantly using two in-vivo assays: the rabbit corneal assay and the chick embryo chorioallantoic membrane (CAM) assay. At the cellular level different steps of angiogenesis, including migration and proliferation of endothelial cells, enzyme production and tube formation, can be assayed in vitro (Auerbach et al., 1991; Cockerill et al., 1995; Knighton et al., 1991). An in-vitro assay has been used to investigate the production of endothelial cell migratory factors by cultured endometrial explants obtained at different stages of the menstrual cycle (Rogers et al., 1992). A subsequent study used immunohistochemical techniques to evaluate endothelial cell proliferation in a similar set of endometrial biopsies (Goodger and Rogers, 1994). Reynolds and co-workers (1992) reported on the induction of a neovascular response in the CAM assay by uterus tissue. However, only two studies has been published with respect to normal human endometrium and the CAM assay (Splawinsky et al., 1988; Peek et al., 1995). In the study of Splawinsky (1988), 9 endometrial samples - cycle day not mentioned - were placed on the CAM as a negative control; five gave a response of 0 and four gave a response of $0.1-1.0$ (arbitrary units from 0 to 4). Peek and co-workers (1995) aliquoted suspensions of endometrium into the eggs. The reactions on the CAM were assessed as having either a positive or a negative angiogenic response. Significantly more positive responses were seen with endometrial suspensions compared to medium only, no comparisons were made to other tissues. The purpose of the present study was to determine whether the CAM assay is a suitable model to assess the angiogenic properties of human endometrial fragments and to develop an accurate and reproducible means of quantitating the angiogenic response.

\section{Material and methods}

\section{Tissue}

Endometrium obtained at cycle day 10 and 12 was collected from volunteers with an ovulatory cycle using a Probet endometrial sampling device (Gynetics, Oisterwijk, Netherlands). The study was approved by the institutional review board of the academisch ziekenhuis Maastricht and all women included in this study signed a written 
informed consent. Endometrium was placed in sterile saline and stripped of blood with a fine forceps. Endometrium was cut into portions of $1.5 \times 2 \mathrm{~mm}$ and explanted onto the CAM within $2 \mathrm{~h}$ after removal of the tissue $(\mathrm{n}=17)$. Control skin tissue was harvested from a mouse and processed similarly prior to explantation $(n=8)$.

\section{Chick embryo chorioallantoic membrane (CAM) model}

Fertile eggs of Lohman-selected White Leghorns were incubated for 3 days at $37^{\circ} \mathrm{C}$, $55 \%$ relative air humidity, while being rotated hourly. At day 3 of incubation, a rectangular window $(1 \mathrm{~cm} \times 1.5 \mathrm{~cm})$ was made in the eggshell. Two milliliters of albumen were withdrawn, using a $21 \mathrm{G}$ needle, through the large blunt edge of the egg. The window was covered with Scotch tape to prevent dehydration (Le Noble et al., 1993). The eggs were replaced in the incubator without rotation until day 10 when test materials, either proliferative endometrium or mouse skin, were placed on the CAM. Additional controls consisted of normal unmanipulated CAM $(n=12)$. During further incubation for 4 days, the developing vasculature of the CAM was observed once daily under a stereomicroscope. At the same time the CAM was checked for signs of inflammation, such as opacification. To prevent infection, instruments were sterilized and all manipulations were performed within a sterile laminar flow hood. At day 14, color photographs of the area involved were taken through a microscope. Subsequently the CAM was excised and fixed with $3.7 \%$ buffered formaldehyde. Paraffin sections were cut and stained with hematoxylin and eosin for histological evaluation.

\section{Analysis of angiogenesis}

The CAM was photographed in ovo using a Wild M8 stereomicroscope equipped with a Nikon F301 camera, on Kodak 64 ASA color-slide film. A Quantimet 570 image processing and analysis system (Leica, Cambridge) displayed the slide on a color image monitor using a $\mathrm{COHU}$, high performance color $\mathrm{CCD}$ camera. The green channel was selected to obtain the best image. After checking for correct set-up (position, magnification, focus), four images per slide were displayed and stored on disc. In a computerized image analysis system, a collage of the four images was made to obtain one representative image of each slide with an optimal resolution.

The vascular density index (VDI) was calculated as an estimate of the overall vascular response to the various explants. A grid containing concentric circles was superimposed on the image. The first circle was $2 \mathrm{~mm}$ in diameter and the subsequent circles were $0.25 \mathrm{~mm}$ apart. The number of vessels, arterioles and venules, which intersected the first five circles were counted ( $47.124 \mathrm{~mm}$ total circumference). The vessels were counted at a $\times 42$ final magnification. This technique allows quantitation of vessels as small as $10-15 \mu \mathrm{m}$ in diameter. Only vessels with a clearly defined vascular wall were counted. Using a computerized image analysis system it was possible to count each image of the in-vivo situation twice under identical circumstances. The average of the counts was taken as the vascular density index for that particular CAM. The difference between the two counts was used to assess the intra-observer variability. 


\section{Statistics}

Descriptive statistics (mean $\pm 95 \%$ confidence interval, median and percentiles) were calculated for each experimental group and then compared using the non-parametric Mann-Whitney U-test. Data are presented as box plots showing 10th and 90th percentiles, 25 th and 75 th percentiles, medians and outliers.

To assess the intra-observer variability we calculated variability by dividing the SD of the paired differences by the overall mean VDI. A visual representation of the level of variability was obtained by plotting the difference between the two counts against the corresponding mean, according to Bland and Altman (1986) and Brennan and Silman (1992).

\section{Results}

An in ovo photograph of the 14-day unmanipulated CAM is presented in Figure 1.

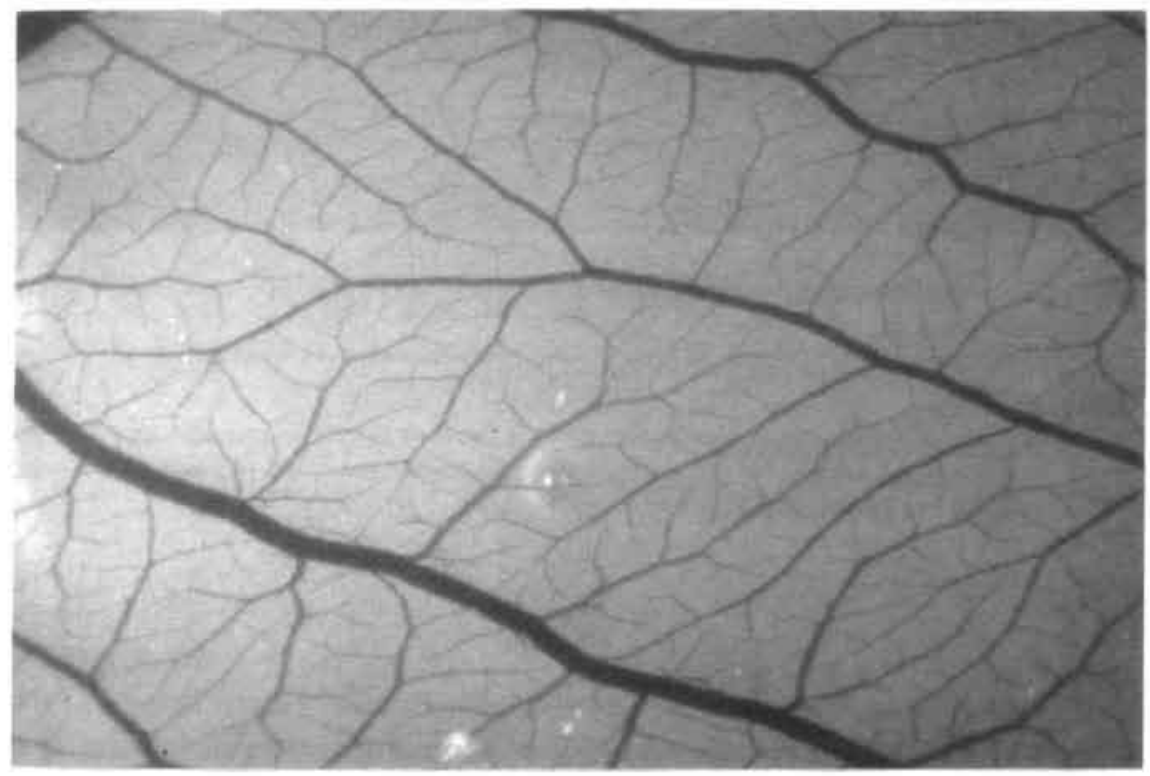

Figure 1 Normal unmanipulated CAM at day 14 of incubation

The angiogenic response of the CAM was characterized by numerous vessels converging on the endometrium explant, as can be seen in Figure 2. This figure shows the computerized image with the superimposed circular grid for determining the VDI. Angiogenesis was less pronounced when mouse skin was placed on the CAM.

The median, the 10th, 25th, 75th and 90th percentiles and the p-values are shown in Figure 3 . The VDI of the CAM with proliferative endometrium $(256.9 \pm 25.1)$ was significantly greater than the VDI of mouse skin $(201.4 \pm 12.9, \mathrm{P}<0.007)$ which in turn was significantly greater than the VDI of the normal, unmanipulated CAM $(153.0 \pm$ $10.5, \mathrm{P}<0.001$ ).

In the intra-observer variability study we calculated a mean difference of the two counts of -3.7 with a standard deviation of 11.0 , resulting in limits of agreement 


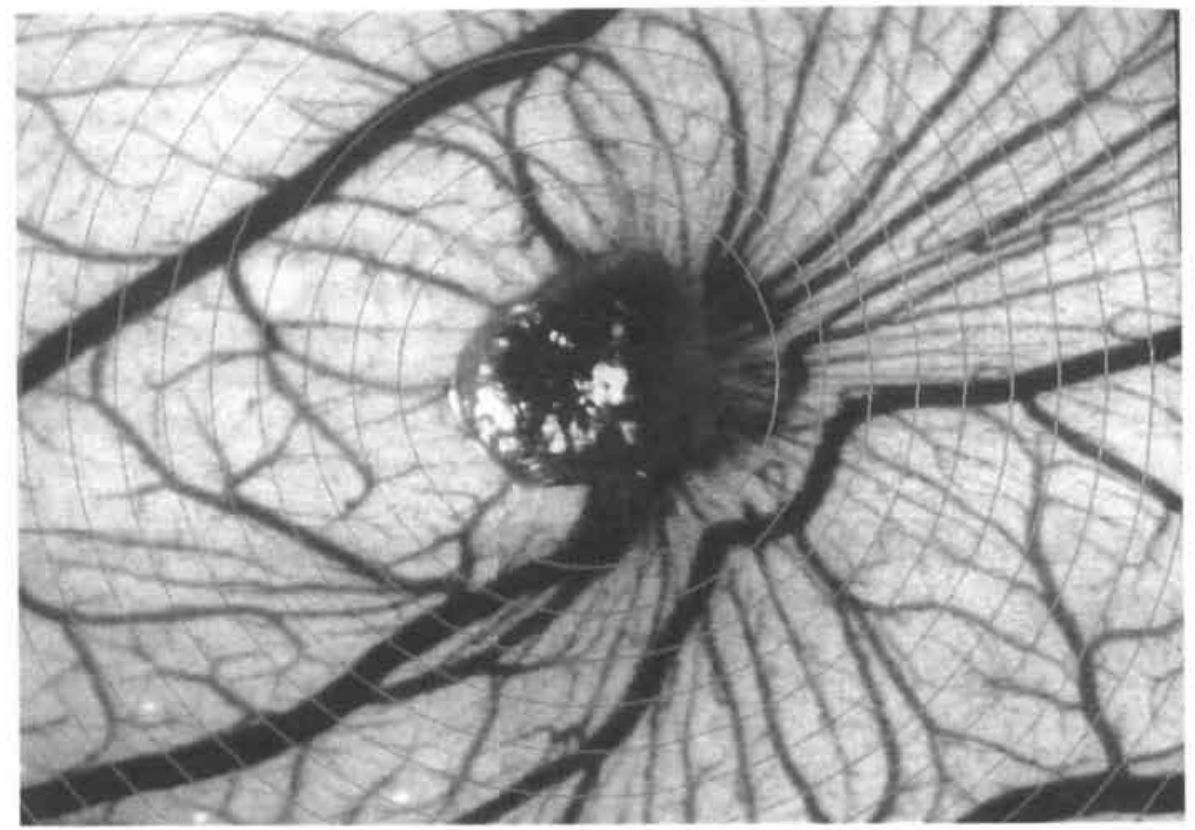

Figure 2 Computerized image of the vascular pattern of the CAM at day 14; endometrium explant with the superimposed circular grid.

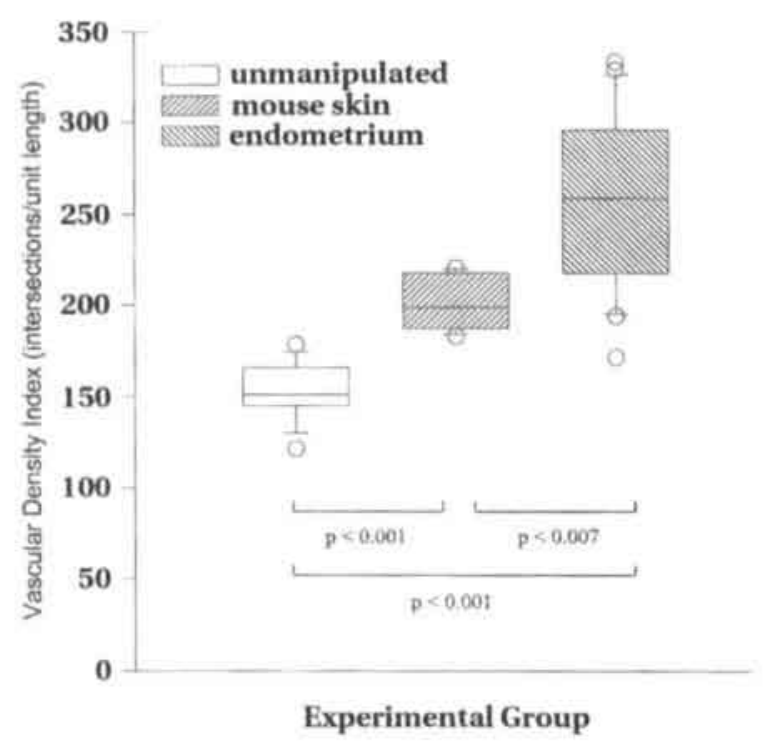

Figure 3 Effects of proliferative endometrium and mouse skin control explants on vascular density in the CAM angiogenesis assay as compared to unmanipulated CAM.

(mean \pm 2 SD) of -25.8 and 18.4 (Figure 4). As shown in Figure 4 the level of precision is not related to the mean VDI, since higher average counts do not result in larger dif- 
ferences. The intra-observer variability, calculated by dividing the SD of the paired differences (11.0) by the overall mean VDI (211.2), was $5.2 \%$.

Histologically, the directional pattern of the newly formed vessels surrounding the endometrium explants was obvious. However, neither penetration of the CAM vessels into the endometrium nor invasion of the endometrium into the CAM was observed, the epithelial lining remained intact. Evidence for an inflammatory response in any of the cultures was lacking.

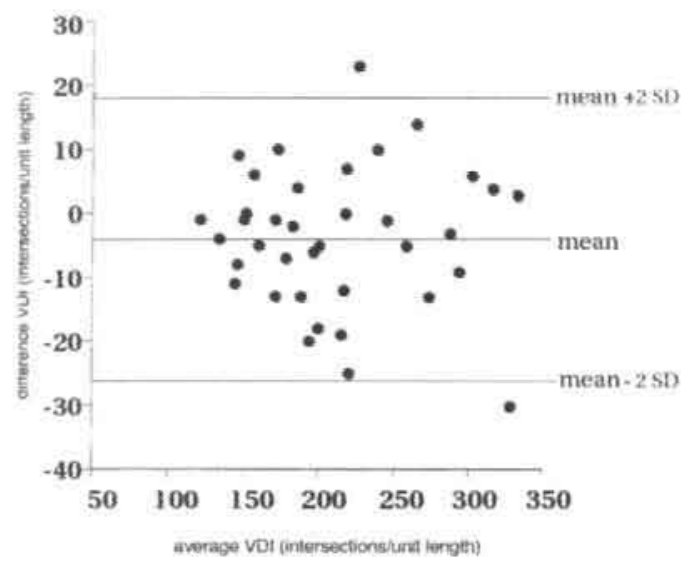

Figure 4 Intra-observer variability. Difference in VDI plotted against the mean VDI of two counts by one observer (according to Bland and Altman, 1986).

\section{Discussion}

In the present study we have assessed the suitability of the chick embryo chorioallantoic membrane assay to quantitate the angiogenic properties of human endometrium. Grafting of tissue onto the CAM is a procedure that has been used by embryologists for more than 50 years. Since the early chick embryo lacks a mature immune system xenografts from mammalian species are able to become established and grow. The model has been used widely to study tumor angiogenesis (Folkman et al., 1979), but the CAM assay has some limitations and problems. An explant may cause a mechanical effect, inflammation may occur, and quantitating the response is very difficult (Auerbach et al., 1991; Knighton et al., 1991). In the present study we have tried to minimize these problems. To estimate the effect of physical forces we have used portions of skin tissue similar in size and weight as negative controls. Skin samples have been applied previously as control tissue in a study on cancer-induced angiogenesis, and these explants appeared not to stimulate the directional pattern of neovascularization in the CAM (Petruzelli et al., 1993). We have demonstrated that skin tissue has some influence on the CAM as compared to unmanipulated CAM, but 
this effect is significantly less than that of endometrium. The angiogenic properties of proliferative endometrium therefore are not due to a mechanical effect alone. Angiogenesis is associated with inflammation. Any tissue which invokes an inflammatory response in the CAM assay may cause angiogenesis indirectly (Knighton et al., 1991). In these experiments signs of inflammation were not observed.

Quantitation of angiogenesis using the CAM assay has been attempted by scoring the extent of vascularization on a graded scale of 0-4 (Vu et al., 1985). Jacob and Voss (1984; Voss et al., 1984) quantitated the vascular response in the CAM by using automatic image analysis. The reproducibility of their measurements was about $12 \%$. The application of stereological principles to the analysis of microcirculation represents a useful tool for obtaining quantitative information (Schmid-Schoenbein et al., 1977). Several stereological techniques have been described to quantitate an angiogenic response in the CAM (Harris-Hooker et al., 1983; Dusseau et al., 1986; Dusseau and Hutchins 1988; 1993). A vascular density index was calculated by counting the number of intercepts of vessels with concentric circles of a grid, which was placed over the formalin-fixed CAM, or over a photograph of the excised membranes. The VDI obtained in this way is an estimate of arteriolar and venular number and length (Dusseau and Hutchins, 1988). In the present study we have improved on this method of quantitation. The circular grid was placed over a photograph, which was made in ovo. So, we were able to obtain the VDI in an in vivo situation, thus preventing blood draining out of the vessels after excision, and artifacts of formalin fixation, such as shrinkage and tissue distortion. Using a computerized image analysis system to count the vessels. our intra-observer variability of $5.2 \%$ compared favorably to those obtained by previous investigators.

When proliferative endometrium is explanted onto the CAM, there is a significant increase in the VDI compared to skin tissue. Although it has been postulated earlier in the literature that uterus tissue may induce a neovascular response in the chick embryo CAM assay, the present study provides direct evidence that endometrial fragments, obtained in the proliferative phase, do induce angiogenesis in this model. We decided to standardize tissue collection to be performed on day 10-12 of the proliferative phase of the cycle, in order to prevent cyclic endometrial effects to affect the results. The morphology of the epithelial lining of the CAM remained intact. The vessels surrounding the endometrium explant, though increased in number, did not penetrate into the endometrium. Neither were endometrial cells found to invade the CAM. We hypothesize endometrial fragments to release soluble angiogenic factors that induce local formation of new vessels in the surroundings of the fragment.

In conclusion, the CAM assay is a suitable model for investigating angiogenic properties of human endometrium. Our method allows for reliable and reproducible quantitation of the angiogenic response. It offers possibilities for studying menstrual cycle dependent changes in angiogenic properties of endometrium and it allows for investigating peritoneal changes in response to endometrial seeding in a model mimicking the early phases of the development of endometriosis. 


\section{Acknowledgments}

The authors thank Lilian Kessels from the Department of Pharmacology for technical assistance.

\section{References}

Auerbach, R., Auerbach, W. and Polakowski, I. (1991) Assays for angiogenesis: a review. Pharmac. Ther., 51, 1-11.

Bland, J.M. and Altman, D.G. (1986) Statistical methods for assessing agreement between two methods of clinical measurement. Lancet, i, 307-310.

Brennan, P. and Silman, A. (1992) Statistical methods for assessing observer variability in clinical measures. BMJ, 304, 1491-1494.

Cockerill, G.W., Gamble, J.R. and Vadas, M.A. (1995) Angiogenesis: models and modulators. Int. Rev. Cytol., 159, 113-160.

Dusseau, J.W., Hutchins, P.M. and Malbasa, D.S. (1986) Stimulation of angiogenesis by adenosine on the chick chorioallantoic membrane. Circ. Res., 59, 163-170.

Dusseau, J.W. and Hutchins, P.M. (1988) Hypoxia-induced angiogenesis in chick chorioallantoic membranes: a role for adenosine. Respir. Physiol., 71, 33-44.

Dusseau, J. and Hutchins, P.M. (1993) Calcium entry blockers stimulate vasoproliferation on the chick chorioallantoic membrane. Int. J. Microcirc. Clin. Exp., 13, 219231.

Findlay, J.K. (1986) Angiogenesis in reproductive tissues. J. Endocr., 111, 357-366.

Folkman, J., Haudenschild, B.C. and Zetter, B.R. (1979) Long-term culture of capillary endothelial cells. Proc. Natn. Acad. Sci. USA, 76, 5217-5221.

Folkman, J. (1985) Tumor angiogenesis. Adv. Cancer Res., 43, 175-203.

Goodger, A.M. and Rogers, P.A.W. (1994) Endometrial endothelial cell proliferation during the menstrual cycle. Hum. Reprod., 9, 399-405.

Gordon, J.D., Shifren, J.L., Foulk, R.A., Taylor, R.N. and Jaffe, R.B. (1995) Angiogenesis in the human female reproductive tract. Obstet. Gynecol. Surv., 50, 688-697.

Harris-Hooker, S.A., Gajdusek, C.M., Wight, T.N. and Schwartz, S.M. (1983) Neovascular responses induced by cultured aortic endothelial cells. J. Cell. Physiol., $114,302-310$.

Jakob, W. and Voss, K. (1984) Utilization of image analysis for the quantification of vascular responses in the chick chorioallantoic membrane. Exp. Pathol., 26, 93-99.

Klagsbrun, M. and D'Amore, P.A. (1991) Regulators of angiogenesis. Ann. Rev. Physiol., 53, 217-239.

Klauber, N., Rohan, R.M., Flynn, E. and D'Amato, R.J. (1997) Critical components of the female reproductive pathway are suppressed by the angiogenesis inhibitor AGM1470. Nature Med., 3, 443-446.

Knighton, D.R., Fiegel, V.D. and Phillips, G.D. (1991) The assay of angiogenesis. Clin. Exp. Appr. Derm. Epiderm. Rep., 291-299.

Le Noble, F.A.C., Schreurs, N.H.J.S., Van Straaten, H.W.M., Slaaf, D.W., Smits, J.F.M., Rogg, H. and Struijker Boudier, H.A.J. (1993) Evidence for a novel angiotensin II receptor involved in angiogenesis in chick embryo chorioallantoic membrane. Am. J. Physiol, 264, R460-R465. 
Peek, M.J., Markham, R. and Fraser, I.S. (1995) Angiogenic activity in normal and dysfunctional uterine bleeding human endometrium; as measured by the chick chorioallantoic membrane assay. Exp. Toxic. Pathol., 47, 397-402.

Petruzelli, G.J., Johnson, J.T., Snyderman, C.H. and Myers, E.N. (1993) Angiogenesis induced by head and neck squamous cell carcinoma xenografts in the chick embryo chorioallantoic membrane model. Ann. Otol. Rhinol. Laryngol., 102, 215-221.

Reynolds, L.P., Killilea, S.D. and Redmer, D.A. (1992) Angiogenesis in the female reproductive system. FASEB J., 6, 886-892.

Rogers, P.A.W., Abberton, K.M. and Susil, B. (1992) Endothelial cell migratory signal produced by human endometrium during the menstrual cycle. Hum. Reprod., 7 , 1061-1066.

Schmid-Schoenbein, G.W., Zweifach, B.W. and Kovalcheck, S. (1977) The application of stereological principles to morphometry of the microcirculation in different tissues. Microvasc. Res., 14, 303-317.

Splawinski, J., Michna, M., Palczak, R., Konturek, S. and Splawinska, B. (1988) Angiogenesis: Quantitative assessment by the chick chorioallantoic membrane assay. Meth. and Find. Exptl. Clin. Pharmacol., 10, 221-226.

Voss, K., Jacob, W. and Roth, K. (1984) A new image analysis method for the quantification of neovascularization. Exp. Pathol., 26, 155-161.

Vu, M.T., Smith, C.F., Burger, P.C. and Klintworth, G.K. (1985) An evaluation of methods to quantitate the chick chorioallantoic membrane assay in angiogenesis. Lab. Invest., 53, 499-508. 


\section{Chapter 6}

\section{Endometrial angiogenesis throughout the human menstrual cycle}

Jacques W.M. Maas, Patrick G. Groothuis, Gerard A.J. Dunselman, Anton F.P.M. de Goeij, Harry A.J. Struijker Boudier, Johannes L.H. Evers

Human Reproduction, in press
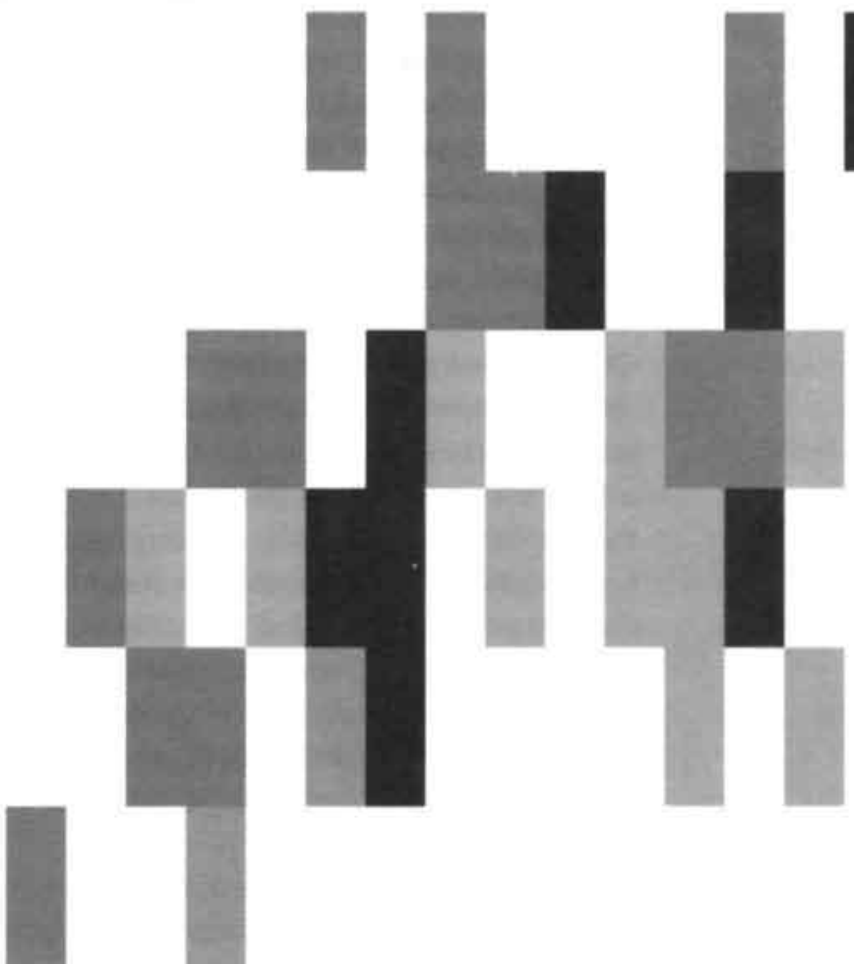


\begin{abstract}
The timing and mechanisms of new blood vessel formation in the endometrium during the menstrual cycle are still largely unknown. In the present study we used the chick embryo chorioallantoic membrane (CAM) as an in vivo assay for angiogenesis to assess the angiogenic potential of endometrium obtained at different stages of the menstrual cycle. Endometrial fragments were explanted onto the CAM and after 4 days of incubation colour slides of the treated area were taken in ovo through a microscope for computerized image analysis. The vascular density index (VDI), a stereological estimate of vessel number and length, was obtained by counting the intersections of vessels with five concentric circles of a circular grid superimposed on the computerized image. Endometrial tissue, independent of the stage of the menstrual cycle, caused a significant increase in VDI as compared to the negative controls. There was a significant difference in angiogenic response between the stages of the menstrual cycle $(\mathrm{P}=0.01)$. The VDIs of the early proliferative, early secretory and late secretory stage were significantly higher than the VDI of the late proliferative phase. Using the CAM in vivo angiogenesis assay we demonstrated that human endometrium has angiogenic potential throughout the menstrual cycle. Besides, this increased angiogenic activity showed a cyclic variation. Elongation of existing vessels during the early proliferative phase as well as growth and coiling of the spiral vessels during the secretory phase may demand for higher angiogenic activity than outgrowth and maintenance of vessels during the late proliferative phase.
\end{abstract}




\section{Introduction}

Angiogenesis is a fundamental process of generating new capillary blood vessels (Folkman, 1985). In the healthy human adult angiogenesis is rare, apart from the female reproductive system where angiogenesis occurs in the ovarian follicle, corpus luteum and uterine endometrium (Findlay, 1986; Gordon et al., 1995). Under these physiological circumstances angiogenesis is highly regulated, which means being turned on for brief periods and then completely inhibited (Folkman and Shing, 1992). Some diseases, e.g. cancer, proliferative diabetic retinopathy and peripheral vascular disease, are driven by persistent unregulated angiogenesis (Klagsbrun and D'Amore, 1991; Folkman and Shing, 1992). In the female reproductive tract, defects in angiogenesis have been suggested to be involved in such disorders as luteal phase defects, endometriosis, pregnancy loss, preeclampsia and cancer (Gordon et al., 1995). Before investigating these pathological conditions, we first have to obtain a better understanding of normal endometrial angiogenesis. Angiogenesis in the human uterus is required to support the reconstruction of endometrium after the menstrual period and to provide a vascularized, receptive endometrium for implantation and placentation three weeks later (Torry et al., 1996). It is not clear, however, which mechanisms control vascular growth in the endometrium and at which stage of the menstrual cycle new blood vessel formation occurs (Rogers, 1996). There are two different types of angiogenesis: sprouting of capillaries from pre-existing vessels, and nonsprouting angiogenesis or intussusception (Folkman, 1985; Risau, 1997; Jain et al., 1997). Sprouting angiogenesis is a multistep process involving degradation of the basement membrane, invasion in stroma, endothelial cell proliferation and migration, and tube formation. Non-sprouting angiogenesis, or intussusceptive capillary growth, can occur by proliferation of endothelial cells inside a vessel, producing a wide lumen that can be split by transcapillary pillars, or fusion and splitting of capillaries (Risau, 1997; Jain et al., 1997). These processes are controlled by an angiogenic switch mechanism, which is triggered by a change in the balance of inducers and inhibitors of angiogenesis (Hanahan and Folkman, 1996). Thus, either an increase in activator concentration, or a reduction in inhibitor levels may lead to new vessel growth.

The purpose of this study is to determine whether human endometrial fragments obtained at different stages of the menstrual cycle are able to induce angiogenesis. The chick embryo chorioallantoic membrane (CAM), which is an established model for studying angiogenesis (Auerbach et al., 1991; Knighton et al., 1991; Cockerill et al., 1995), was used to assess the angiogenic potential of endometrium. This in vivo angiogenesis model permits detailed quantitation of the vascular response in an objective and reproducible way (Maas et al., 1999), allowing comparison of the angiogenic activity in different stages of the menstrual cycle. 


\section{Tissue}

Endometrium was collected using a Probet endometrial sampling device (Gynetics, Oisterwijk, Netherlands) from 22 volunteers with a regular ovulatory cycle. The study was approved by the institutional review board of the university hospital Maastricht and all women included in this study have signed a written informed consent.

Endometrium was placed in sterile saline and stripped of blood clots with a fine forceps. Subsequently the endometrial tissue was carefully sectioned into uniform fragments of $1.5 \times 2 \mathrm{~mm}$ with the aid of a dissecting microscope and explanted at random onto the CAM, within $2 \mathrm{~h}$ after obtaining the tissue. Each CAM contained only one fragment. Endometrial fragments were explanted on 3 to 11 CAMs, depending on the amount of available tissue, which ultimately resulted in a total of 158 CAMs.

Mouse skin tissue was used as a negative tissue control (Petruzelli et al., 1993; Maas et al.,1999) and processed similarly prior to explantation (8 CAMs). In addition, fragments of $1.5 \%$ agarose gel (12 CAMs) similar in size to the endometrial explants were used as negative controls. Similar fragments of low melting point agarose gel containing $10 \mathrm{ng}$ TGF- $\beta 1$ ( 3 CAMs), a well known angiogenic factor, were used as positive controls (Yang and Moses, 1990). Additional controls consisted of normal unmanipulated CAM (12 CAMs).

\section{Chick embryo chorioallantoic membrane (CAM) model}

The assay and method of quantitation used have been described previously (Maas et al., 1999). In short, fertilized eggs were incubated for 3 days at $37^{\circ} \mathrm{C}, 55 \%$ relative air humidity. At day 3 of incubation a rectangular window was made in the eggshell. The window was covered with Scotch tape to prevent dehydration. The eggs were returned to the incubator until day 10 when test materials were placed on the CAM. During further incubation for 4 days the developing vasculature of the CAM was observed each day under a stereomicroscope. At day 14 colour slides of the treated area were taken through a microscope. Subsequently the CAM was excised and fixed with $3.7 \%$ buffered formalin. Paraffin sections were cut and stained with hematoxylin and eosin for histological evaluation.

\section{Analysis}

Each of 193 CAMs was photographed in ovo. The Quantimet 570 image processing and analysis system (Leica, Cambridge, UK) displayed the slide on a monitor. The vascular density index (VDI) was calculated as an estimate of the overall vascular response to the various explants. A grid containing concentric circles was superimposed on the computerized image. The innermost circle was $2 \mathrm{~mm}$ in diameter and the others were $0.25 \mathrm{~mm}$ apart. The number of intersections between the vessels and the first five circles was determined (47.124 mm total circumference). Quantitation was done at a standardized $42 x$ final magnification. Using a computerized image analysis system it was possible to count each image of the in vivo situation twice under identical circumstances. The average of the two counts was taken as the VDI for that 
particular CAM. The difference between the two counts was used to assess the intraobserver variability. We calculated a mean difference of the two counts of 0.07 with a standard deviation of 13.6. The mean VDI of all observations $(n=386)$ was 266.2. The intra-observer variation was $13.6 / 266.2 \times 100=5.1 \%$.

\section{Statistics}

The median VDI was determined for each of the 22 endometrial samples. These median VDIs were divided into 4 menstrual cycle stages, based on the number of days since the onset of the last menstrual period: early proliferative, containing endometrium of cycle day $2,4,5,6$ and 7 (6 patients); late proliferative, containing cycle day $8,9,10,11,12$ and 14 endometrium (7 patients); early secretory, containing endometrium of cycle day $15,16,18$ and 21 (4 patients) and late secretory, containing cycle day 22, 23, 26 and 27 (5 patients). Data are presented as box plots showing 10th and 90 th percentiles, the 25 th and 75 th percentiles, medians and outliers. The KruskalWallis analysis of variance was used to compare the different stages of the menstrual cycle. The non-parametric Mann-Whitney U-test was used to compare the late proliferative stage with each of the other stages and to compare the controls with each other and with each of the menstrual stages. $\mathrm{P} \leq 0.05$ was considered to reflect statistical significance.

\section{Results}

An in ovo photograph of the 14-day unmanipulated CAM is presented in figure $1 \mathrm{~A}$. The orderly arrangement of the vessels with the ladder-like interdigitation is characteristic. Figure $1 \mathrm{~B}$ shows the angiogenic response of the CAM to an endometrium explant: increased density and length of vessels radially converging toward the explant. Figure IC shows the computerized image with the superimposed circular grid for determining the VDI.

Figure 2 shows the median VDI with its 10 th, 25th, 75 th and 90 th percentiles of each endometrial sample $(n=22)$. The medians were used to determine the angiogenic properties of endometrium in four different stages of the menstrual cycle. These data are presented together with the controls in figure 3 . The VDIs of the CAMs containing the negative controls were comparable ( $\mathrm{P}=0.78$ ), the VDI increased significantly when TGF- $\beta$, an angiogenic factor, was added to the agarose gel $(\mathrm{P}=0.004)$. The VDI of the CAM containing endometrium, independent of the stage of the menstrual cycle, was significantly greater than the VDI of the normal unmanipulated CAM $(\mathrm{P}<0.001)$, the CAM containing explants of agarose gel $(\mathrm{P}<0.0008)$ and the CAM containing mouse skin $(\mathrm{P}<0.004)$.

There was a significant difference in angiogenic response between the stages of the menstrual cycle $(\mathrm{P}=0.01)$. The VDIs of the early proliferative, early secretory and late secretory stage did not differ significantly and were similar to the response induced by TGF- $\beta$. The VDIs of these three stages were significantly higher than the VDI of the late proliferative stage (as compared to early proliferative, $\mathrm{P}=0.046$; early secretory, $\mathrm{P}=0.02$; and late secretory, $\mathrm{P}=0.005$ ). 

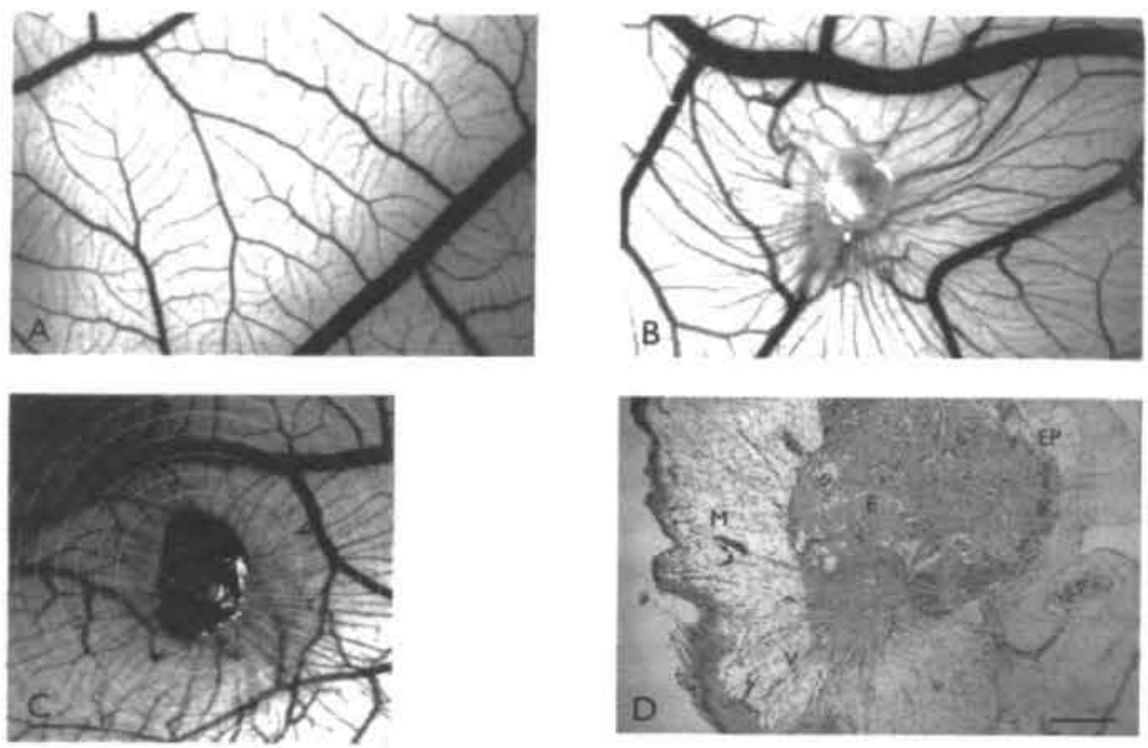

Figure 1 (A) Normal unmanipulated CAM at day 14 of incubation. (B) Vascular pattern of the CAM at day 14 containing endometrium explant of cycle day 7, (C) Computerized image of the vascular pattern of the CAM at day 14: endometrium explant of cycle day 6 with the superimposed circular grid, (D) Light micrograph of a longitudinal section of the CAM at day 14 containing endometrium explant (e) of cycle day 12. The epithelial lining of the CAM (ep) is uninterrupted and there is a clear directional pattern of the blood vessels ( $v$ ) in the mesenchymal layer $(\mathrm{m})$ of the CAM towards the endometrium explant (hematoxylin and eosin; $B a r=375 \mu \mathrm{m})$.

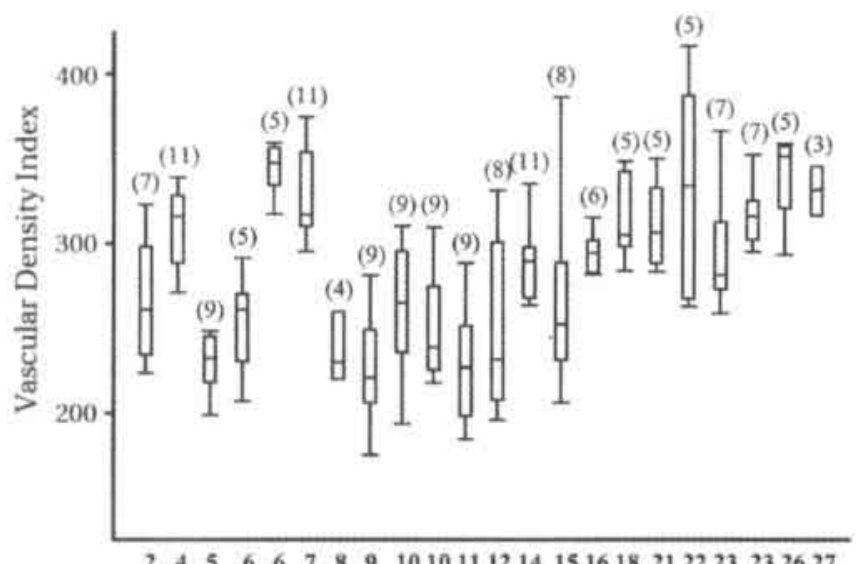

Days since onset last menstrual period

Figure 2 Data of each of the 22 endometrial samples presented as box plots showing medians, 10th, 25th. 75 th and 90 th percentiles. The number of CAMs ( $n$ ) is shown above each box plot. 


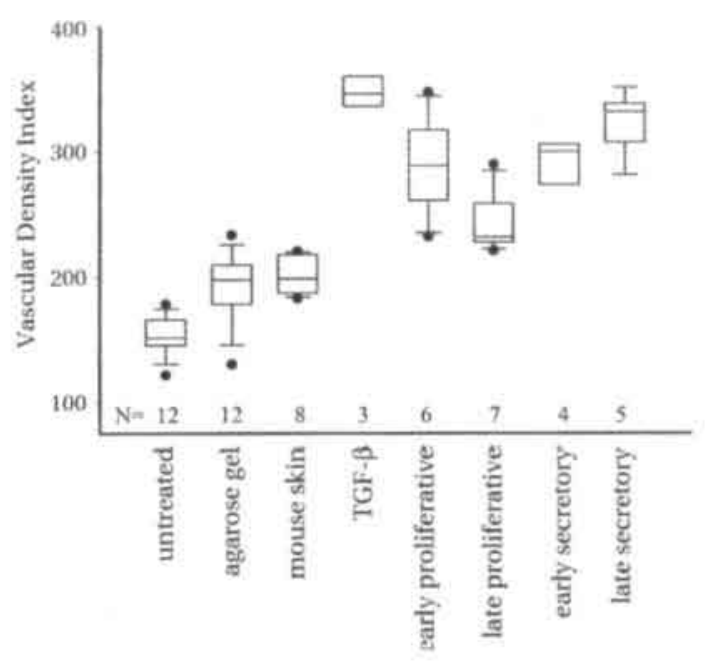

Figure 3 Effects of endometrium from different phases of the menstrual cycle and control explants on vascular density in the CAM angiogenesis assay. Data are presented as box plots showing medians, 10 th, 25 th. 75 th and 90th percentiles and outliers. There is a significant difference in VDI between the stages of the menstrual cycle $(\mathrm{P}=0.01)$.

Morphologically, we observed a clear directional growth pattern of the newly formed vessels towards the endometrium explants. Neither penetration of the vessels into the endometrium nor invasion of the endometrium into the CAM was observed. The explants consisted of viable endometrial stromal as well as glandular cells. Most of the viable stromal cells could be found at the periphery of the explant tissue, along the epithelial lining of the CAM (Figure 1D). These observations were similar in all experimental groups.

\section{Discussion}

In a previous study (Maas et al., 1999) we demonstrated the CAM assay to be a suitable model for investigating angiogenic properties of endometrium and the vascular response has been shown to be quantifiable in an objective and reproducible way. The results of the present study, using the same in vivo CAM angiogenesis assay and method of quantitation, provide direct evidence that endometrial fragments, obtained at different phases of the menstrual cycle, have angiogenic potential. The VDI is significantly increased in the early proliferative, early secretory and late secretory phase as compared to the late proliferative phase. Using fragments of mouse skin and agarose gel as controls we rule out the possibility that the increase in VDI is due to a mechanical effect alone. Moreover, the significant increase in VDI when TGF- $\beta$ is added to the agarose gel, supports the validity of this method.

Given the physiological and pathological importance of angiogenesis, much effort has been devoted to the isolation, characterization, and purification of factors that can either stimulate or inhibit angiogenesis (Klagsbrun and D'Amore, 1991). As for 
endometrium, most attention has been paid to vascular endothelial growth factor (VEGF) (Charnock-Jones et al., 1993; Li et al., 1994; Torry et al., 1996; Shifren et al., 1996; Donnez et al., 1998; Gargett et al., 1999). Since endometrial growth and function is controlled by sex steroids, the influence of these steroids on VEGF expression has been studied (Charnock-Jones et al., 1993; Shifren et al., 1996; Greb et al., 1997; Huang et al., 1998). From these studies, it has not become clear whether VEGF regulates endometrial angiogenesis throughout the menstrual cycle, nor how steroids affect this process.

According to the hypothesis that changes in the balance of inducers and inhibitors of angiogenesis may activate the angiogenic switch (Hanahan and Folkman, 1996). It is highly unlikely that only one factor is responsible for the angiogenic potential of a specific tissue. Therefore, we reasoned that, in addition to studying individual angiogenic factors, the overall angiogenic activity of endometrium should be studied in a bioassay. Rogers and coworkers (1992) used an in vitro angiogenesis bioassay to demonstrate production of an endothelial migratory signal by cultured human endometrial explants. The authors showed that two significant peaks of migratory signal occur, one during early proliferative phase and one during mid-late proliferative phase. There was a significant drop in early-mid proliferative phase. However, no increase of endometrial endothelial cell proliferation across the menstrual cycle could be identified in a subsequent immunohistochemical study (Goodger and Rogers, 1994). Therefore, Rogers and coworkers (1998) suggested that endometrial angiogenesis occurs by elongation and intussusception rather than sprout formation. In the present study we quantitated the angiogenic response by using a standardized stereological technique to obtain the VDI (Harris-Hooker et al., 1983; Dusseau et al., 1988; Maas et al., 1999). The VDI obtained in this way has been considered a function of both vessel number and length (Dusseau et al., 1988). However, Strick and coworkers (1991), comparing different morphometric measurements of vascularity, concluded that VDI is a function of vessel length rather than number of vessels. By assessing the VDI in an in vivo bioassay as a measure of endometrial angiogenesis we took into account the possibility that elongation of existing vessels, which is the nonsprouting type of angiogenesis (Risau 1997), may be of importance in this process. We found a cyclic variation in angiogenic potential of human endometrium, with a nadir in the late proliferative phase and significantly higher levels in the other phases. These findings correspond with other reports in which increased expression of VEGF mRNA was found in the secretory endometrium as compared to proliferative endometrium. Maximum levels of VEGF mRNA expression in the glands and VEGF immunostaining in the stroma were found in the menstrual phase (Charnock-Jones et al., 1993; Shifren et al., 1996; Torry et al., 1996; Gargett et al., 1999). During the (pre)menstrual phase of the cycle both production and release of endothelins by endometrial cells are increased (Ohbuchi et al., 1995). These potent vasoconstrictors act on the spiral arterioles in the endometrium, resulting in reduction of oxygen tension in this tissue (Smith, 1998). The endometrial stromal cells respond to this hypoxic state by producing increasing levels of VEGF (Popovici et al., 1999). The increase in VEGF levels in the early proliferative endometrium may be responsible for elongation of the 
existing vessels, essential for tissue reconstruction in this phase of the cycle. In the secretory phase, the high angiogenic potential of endometrium may be necessary for both elongation and coiling of the spiral arterioles. The role of VEGF in these processes is still not clear. During the late proliferative phase angiogenesis is mainly required for further outgrowth and maintenance of the vasculature. Evidently, for this event the angiogenic potential does not need to be as high as for elongation and coiling of the vessels in the other phases of the menstrual cycle.

In the present study we have focussed on normal endometrial angiogenesis. Moreover, this model offers possibilities for studying angiogenesis dependent disorders, such as endometriosis. The appearance of the blood vessels radiating towards the endometrial fragment on the CAM, as demonstrated in this study, resembles the typical endometriotic lesions surrounded by an hypervascularized area seen at laparoscopy. It has to be elucidated if endometrial fragments, that reach the peritoneal cavity during menstruation, are angiogenic and able to induce their own blood supply for further development into an endometriotic lesion.

In conclusion, human endometrium is angiogenic throughout the menstrual cycle. This increased angiogenic potential shows a cyclic variation, which is in accordance with the physiological changes of endometrium as well as endometrial vasculature during the cycle.

\section{Acknowledgments}

The authors thank Lilian Kessels from the Department of Pharmacology for excellent technical assistance and Pieter Leffers from the Department of Epidemiology for expert advice on the method of statistical analysis. 


\section{References}

Auerbach, R., Auerbach, W. and Polakowski, I. (1991) Assays for angiogenesis: a review. Pharmacol. Ther., 51, 1-11.

Charnock-Jones, D.S., Sharkey, A.M., Rajput-Williams, J. et al. (1993) Identification and localization of alternately spliced mRNAs for Vascular Endothelial Growth Factor in human uterus and estrogen regulation in endometrial carcinoma cell lines. Biol. Reprod., 48, 1120-1128.

Cockerill, G.W., Gamble, J.R. and Vadas, M.A. (1995) Angiogenesis: models and modulators. Int. Rev. Cytol., 159, 113-160.

Donnez, J., Smoes, P., Gillerot, S. et al. (1998) Vascular Endothelial Growth Factor (VEGF) in endometriosis. Hum. Reprod., 13, 1686-1690.

Dusseau, J.W. and Hutchins, P.M. (1988) Hypoxia-induced angiogenesis in chick chorioallantoic membranes: a role for adenosine. Respir. Physiol., 71, 33-44.

Findlay, J.K. (1986) Angiogenesis in reproductive tissues. J. Endocrinol,, 111, 357-366. Folkman, J. (1985) Tumor angiogenesis. Adv. Cancer Res., 43, 175-203.

Folkman, J. and Shing, Y. (1992) Angiogenesis. J. Biol. Chem., 267, 10931-10934.

Gargett, C.E., Lederman, F.L., Lau, T.M. et al. (1999) Lack of correlation between vascular endothelial growth factor production and endothelial cell proliferation in the human endometrium. Hum. Reprod., 14, 2080-2088.

Goodger (Macpherson), A.M. and Rogers, P.A.W. (1994) Endometrial endothelial cell proliferation during the menstrual cycle. Hum. Reprod., 9, 399-405.

Gordon, J.D., Shifren, J.L., Foulk, R.A., et al. (1995) Angiogenesis in the human female reproductive tract. Obst. Gynecol. Surv., 50, 688-697.

Greb, R.R., Heikinheimo, O., Williams, R.F. et al. (1997) Vascular endothelial growth factor in primate endometrium is regulated by oestrogen-receptor and progesteronreceptor ligands in vivo. Hum. Reprod., 12, 1280-1292.

Hanahan, D. and Folkman, J. (1996) Patterns and emerging mechanisms of the angiogenic switch during tumorigenesis. Cell, 86, 353-364.

Harris-Hooker, S.A., Gajdusek, C.M., Wight, T.N., et al. (1983) Neovascular responses induced by cultured aortic endothelial cells. J. Cell. Physiol.,114, 302-310.

Huang, J.C., Liu, D.Y. and Dawood, M.Y. (1998) The expression of vascular endothelial growth factor isoforms in cultured human endometrial stromal cells and its regulation by 17-oestradiol. Mol. Hum. Reprod., 4, 603-607.

Jain, R.K., Schlenger, K., Höckel, M. and Yuan, F. (1997) Quantitative angiogenesis assays: Progress and problems. Nature Med., 3, 1203-1208.

Klagsbrun, M. and D'Amore, P.A. (1991) Regulators of angiogenesis. Annu. Rev. Physiol., 53, 217-239.

Knighton, D.R., Fiegel, V.D. and Phillips, G.D. (1991) The assay of angiogenesis, Prog. Clin. Biol. Res., 365, 291-299.

Li, X.F, Gregory, J. and Ahmed, A. (1994) Immunolocalisation of Vascular Endothelial Growth Factor in human endometrium. Growth Factors, 11, 277-282.

Maas, J.W.M., Le Noble, F.A.C., Dunselman, G.A.J. et al. (1999) The chick embryo chorioallantoic membrane as a model to investigate the angiogenic properties of human endometrium. Gynecol. Obstet. Invest., 48, 108-112. 
Ohbuchi, H., Nagai, K., Yamaguchi, M. et al. (1995) Endothelin-1 and big endothelin1 increase in human endometrium during menstruation. Am. J. Obstet. Gynecol., 173, 1483-1490.

Petruzelli, G.J., Johnson, J.T., Snyderman, C.H. et al. (1993) Angiogenesis induced by head and neck squamous cell carcinoma xenografts in the chick embryo chorioallantoic membrane model. Ann. Otol. Rhinol. Laryngol., 102, 215-221.

Popovici, R.M., Irwin, J.C., Giaccia, A.J. et al. (1999) Hypoxia and cAMP stimulate Vascular Endothelial Growth Factor (VEGF) in human endometrial stromal cells: potential relevance to menstruation and endometrial regeneration. J. Clin. Endocrinol. Metab., 84, 2245-2248.

Risau, W. (1997) Mechanisms of angiogenesis. Nature, 386, 671-674.

Rogers, P.A.W., Abberton, K.M. and Susil, B. (1992) Endothelial cell migratory signal produced by human endometrium during the menstrual cycle. Hum. Reprod., 7 , 1061-1066.

Rogers, P.A.W. (1996) Structure and function of endometrial blood vessels. Hum. Reprod. Update, 2, 57-62.

Rogers, P.A.W., Lederman, F. and Taylor, N. (1998) Endometrial microvascular growth in normal and dysfunctional states. Hum. Reprod. Update, 4, 503-508.

Shifren, J.L., Tseng, J.F., Zaloudek, C.J. et al. (1996) Ovarian steroid regulation of vascular endothelial growth factor in the human endometrium: implications for angiogenesis during the menstrual cycle and in the pathogenesis of endometriosis. J. Clin. Endocrinol. Metab., 81, 3112-3118.

Smith, S.K. (1998) Angiogenesis, vascular endothelial growth factor and the endometrium. Hum. Reprod. Update, 4, 509-519.

Strick, D.M., Waycaster, R.L., Montani, J. et al. (1991) Morphometric measurements of chorioallantoic membrane vascularity: effects of hypoxia and hyperoxia. Am. J. Physiol., 260, H1385-H1389.

Torry, D.S., Holt, V.J., Keenan, J.A. et al. (1996) Vascular endothelial growth factor expression in cycling human endometrium. Fertil. Steril., 66, 72-80.

Yang, E.Y. and Moses, H.L. (1990) Transforming Growth Factor $\beta 1$-induced changes in cell migration, proliferation, and angiogenesis in the chicken chorioallantoic membrane. J. Cell. Biol., 111, 731-741. 


\section{Chapter 7}

Tumor necrosis factor- $\alpha$ but not interleukin$1 \beta$ or interleukin-8 concentrations correlate with angiogenic activity of peritoneal filuid from patients with minimal to mild endometriosis

Jacques W.M. Maas, Carlos Calhaz-Jorge, Gerben ter Riet, Gerard A.J. Dunselman, Anton F.PM. de Goeij, Harry A.J. Struijker Boudier

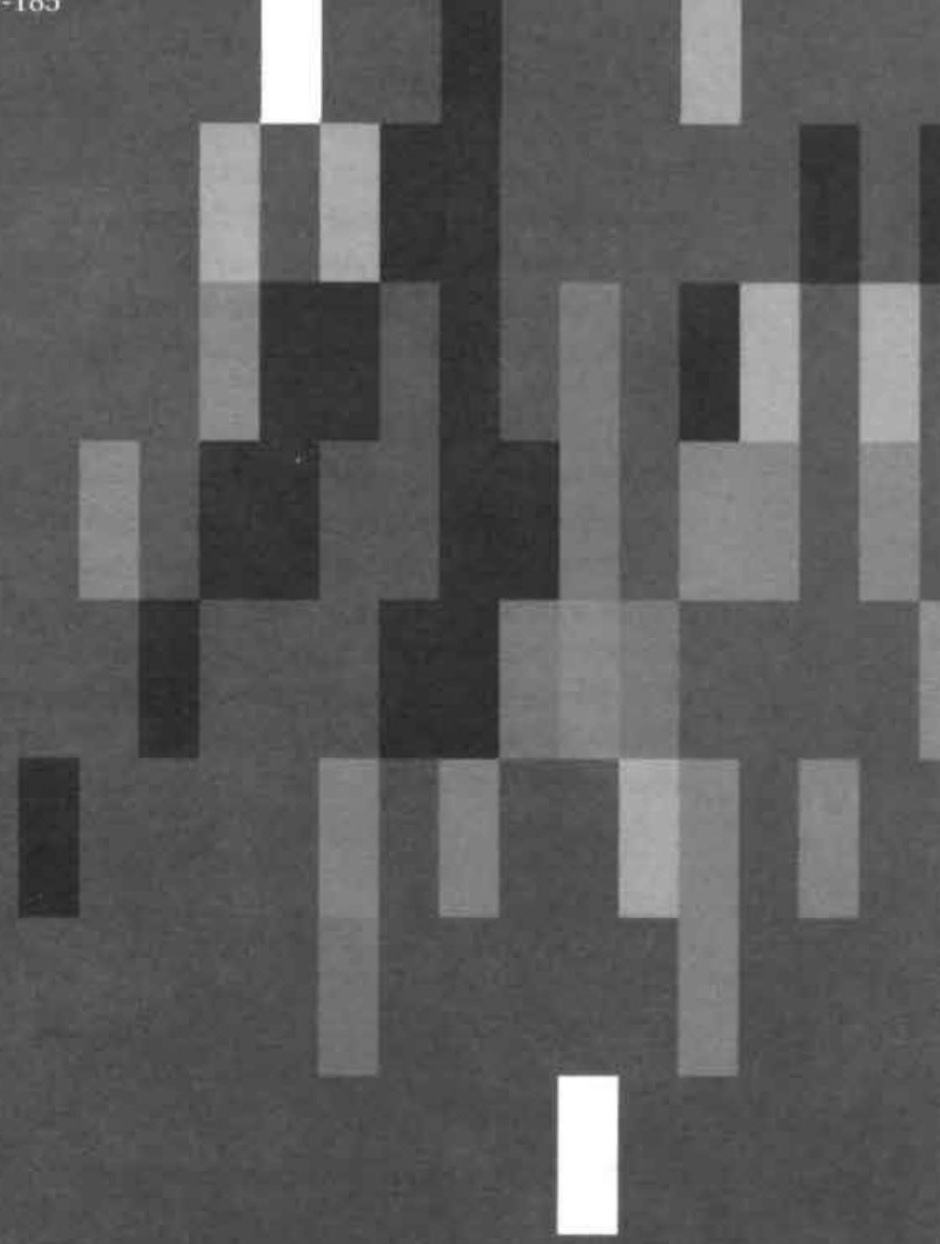




\begin{abstract}
The objective of this study was to assess the angiogenic activity of peritoneal fluid from women with minimal to mild endometriosis and to investigate the relationship between this angiogenic activity and the concentration of some macrophage-derived angiogenic factors or clinical variables, such as phase of menstrual cycle, type of lesion and revised American Society for Reproductive Medicine classification.

Peritoneal fluid from 52 female volunteers with laparoscopic findings of minimal to mild endometriosis was collected at the start of laparoscopy. A standard amount of peritoneal fluid was applied to the chick embryo chorioallantoic membrane assay. The angiogenic response was assessed by determining the vascular density index. Eighty-five percent of the peritoneal fluid samples induced angiogenesis in the chick embryo chorioallantoic membrane bioassay. Tumor necrosis factor- $\alpha$ and total protein were significantly related to the vascular density index, whereas interleukin-1 $\beta$, interleukin- 8 and the clinical variables appeared to not affect the angiogenic response. The results confirm previous findings of peritoneal fluid angiogenic activity in women with minimal to mild endometriosis and indicate involvement of tumor necrosis factor- $\alpha$.
\end{abstract}




\section{Introduction}

Endometriosis is the presence of endometrial tissue in ectopic locations outside the uterine cavity. Various theories on the pathogenesis of endometriosis have been advanced. The transplantation or implantation theory described by Sampson (1940) remains the most widely accepted. It presumes retrograde transportation of viable endometrial cells during menstruation, adhesion of these cells onto the peritoneum, and subsequent implantation and proliferation. It can be hypothesized that in endometriosis, further outgrowth of adhering endometrial fragments will depend on generation of new capillary blood vessels, as in tumor growth and metastasis (Folkman, 1985; 1994). This hypothesis is supported by the observation that the endometriotic lesions are surrounded by neovascularization (Nisolle et al., 1993). Furthermore, the peritoneal fluid of women with endometriosis is more angiogenic than that from women without endometriosis (Oosterlynck et al., 1993; Taylor et al., 1997). In women with mild endometriosis, increased numbers and activation of pelvic macrophages have been found (Halme et al., 1983; 1987; Dunselman et al., 1988). These activated macrophages can induce angiogenesis by release of proteases, growth factors and other monokines (Polverini et al., 1977; Sunderkötter et al., 1994).

Earlier studies have shown that concentrations of interleukin (IL) - $1 \beta, \mathrm{IL}-8$, and tumor necrosis factor (TNF) $\alpha$ are significantly higher in women with minimal to mild endometriosis than in women without endometriosis. Therefore, it has been hypothesized that these important macrophage-derived angiogenic factors contribute to the development of endometriosis by promoting neovascularization (Fakih et al., 1987; Eisermann et al., 1988; Taketani et al., 1992; Mori et al., 1992; Ryan et al., 1995; Arici et al., 1996; Overton et al., 1996; Gazvani et al., 1998; Iwabe et al., 1998). Indeed, these factors can induce angiogenesis in the cornea bioassay (Leibovich et al., 1987; Fràter-Schröder et al., 1987; Koch et al., 1992; Sunderkötter et al., 1994), but their contribution to the angiogenic properties of peritoneal fluid from women with endometriosis has never been established.

We used the chick embryo chorioallantoic membrane (CAM) assay to investigate the angiogenic activity of peritoneal fluid in women with minimal to mild endometriosis. We also investigated the association between this induced angiogenic response and the concentration of IL-1 $\beta, \mathrm{IL}-8, \mathrm{TNF}-\alpha$ and total protein. Furthermore, we wanted to see whether angiogenesis is related only to the development of endometriosis, or also to the maintenance and progression of the disease; we therefore investigated the association between such clinical variables as phase of menstrual cycle (secretory vs proliferative), revised American Society for Reproductive Medicine (rASRM) classification of endometriosis, and type of lesion (black vs non-black), and angiogenic activity. 


\section{Patients}

Fifty-two patients undergoing laparoscopy for evaluation of infertility $(n=49)$ or sterilization ( $n=3)$, all of whom had stages I or II pelvic endometriosis according to the revised ASRM classification (ASRM, 1997), were recruited for the study. Infertility was defined as > 12 months of delay in conception. None of the women had been receiving hormonal medication for $\geq 2$ months before the surgical procedure or had been pregnant or breast feeding in the previous 6 months. The study was approved by the Institutional Review Board of the Hospital de Santa Maria in Lisbon, Portugal, and informed consent was obtained from the patients.

Phase of the menstrual cycle was determined on the basis of the last menstrual period, ovarian findings during laparoscopy, histologic phase pattern of the endometrium (Noyes et al., 1950), and the date of the menstrual period after surgery. Peritoneal endometriotic lesions were classified as black or nonblack according to their macroscopic morphology by using the criteria of Jansen and Russell (Jansen and Russell, 1986).

\section{Peritoneal fluid collection}

All visible peritoneal fluid was aspirated from the anterior and posterior cul-de-sac via a second puncture using a $2 \mathrm{~mm}$ metal cannula, before any internal manipulation and with the patient still supine. The volume of the peritoneal fluid was recorded, and it was transferred to chilled sterile plastic tubes and kept in ice until arrival to the laboratory. It was then centrifuged at $300 \mathrm{~g}$ for 15 minutes; the supernatant was removed and divided into aliquots and frozen at $-70^{\circ} \mathrm{C}$. Patients whose samples were contaminated with blood from puncture sites were excluded. Protein concentration was determined for each sample by the modified Lowry protein assay (Lowry et al., 1951).

\section{Cytokine assays}

Cytokines were quantitatively measured in a blinded fashion by using commercially available enzyme immunoassay kits. The assays were performed according to the manufacturer's instructions, and none of the kits had measurable cross-reactivity with other relevant cytokines. Innotest hTNF- $\alpha$ (Innogenetics NV, Gent, Belgium) was used to measure TNF- $\alpha$ concentrations. Its sensitivity is $4 \mathrm{pg} / \mathrm{ml}$ and intraassay and interassay variations of $6.3 \%$ and $<10 \%$ were found. The detection limit of the IL$1 \beta$ kit (Quantitine HS ${ }^{\oplus}$, R\&D Systems, Abingdon, United Kingdom) was $0.1 \mathrm{pg} / \mathrm{ml}$ and the intraassay and interassay variations $10 \%-12 \%$ for values $<1 \mathrm{pg} / \mathrm{ml}$ and $<10 \%$ for values $\geq 1 \mathrm{pg} / \mathrm{ml}$. The IL-8 kit (Quantitine ${ }^{\circledR}$ R\&D Systems) is sensitive to $10 \mathrm{pg} / \mathrm{ml}$, and the intraassay and interassay variations were $7.1 \%$ and $<10 \%$, respectively.

\section{Chick embryo chorioallantoic membrane model}

Fertilized eggs of Lohman-selected White Leghorns were incubated for 3 days at $37^{\circ} \mathrm{C}$ in $55 \%$ relative air humidity and were rotated hourly (Maas et al., 1999). At day 3 of incubation, a rectangular window $(1 \mathrm{~cm} \times 1.5 \mathrm{~cm})$ was made in the eggshell. Two mil- 
liliters of albumen was withdrawn by using a needle inserted through the large blunt edge of the egg. The window and the hole were covered with Scotch tape to prevent evaporation. The eggs were returned to the incubator. At day 10 , a silicon ring with an inner diameter of $10 \mathrm{~mm}$ was placed on the CAM. To avoid bacterial contamination, peritoneal fluid was filtered through a $0.20-\mu \mathrm{m}$ Minisart filter (Sartorius AG, Göttingen, Germany), and $65 \mu$ l of peritoneal fluid was subsequently applied inside the ring. Depending on the available amount, each batch of peritoneal fluid was applied to 4-6 CAMs. As a negative control, saline $(0.9 \% \mathrm{NaCl})$ was applied inside the ring $(n=6)$; additional controls consisted of untreated CAMs $(n=6)$.

\section{Analysis of angiogenesis}

At day 14 , the area inside the ring was photographed in ovo by using a Wild M8 stereomicroscope equipped with a Nikon F301 camera (Nikon, Tokyo, Japan), on Kodak 64 ASA color-slide film (Kodak Ltd., Harrow, UK). The slide was displayed on a monitor by using a COHU, high performance color CCD camera (Cohu Inc., Electronic Division, San Diego, CA). A grid containing concentric circles was superimposed on this computerized image. The first and innermost circle was $3 \mathrm{~mm}$ in diameter, and the others were $0.75 \mathrm{~mm}$ apart. The vascular density index (VDI) was obtained by counting the number of intercepts between the vessels and the first five circles, at a final magnification of x14. The VDI is an estimate of the overall vascular response to the peritoneal fluid inside the ring. The researcher who did the counting was blinded to the experimental status of the group. To assess intraobserver variability 12 randomly chosen images were counted twice and variation was calculated by dividing the SD of the paired differences by the overall mean VDI of the 24 counts. We calculated a mean difference of the two counts of 11 with a standard deviation of 21.3 . The resulting intraobserver variation was $5.3 \%(21.3 / 401.3 \times 100)$.

\section{Statistical Analysis}

The median VDI and interquartile ranges $(25 \%$ and $75 \%$ percentiles) were calculated for each experimental group. A nonparametric Mann-Whitney U-test was used to compare each of the 52 peritoneal fluid samples with saline and the unmanipulated CAM.

Two separate multivariable linear regression analyses were performed in which the median VDI was the dependent variable. The first analysis focussed on the substances measured in peritoneal fluid (IL-1 $\beta$, IL- 8 , TNF- $\alpha$ and protein). The second was restricted to the clinical variables: revised ASRM score, phase of menstrual cycle (secretory vs proliferative), and type of lesion (black vs non-black). The IL- 8 and IL$1 \beta$ concentrations showed skewed distributions and were entered into the analysis after $\log$ transformation. In the first analysis, the independent variables were entered as continuous variables. The variables in the second analysis were modeled as dummy variables by using two dummies to represent three revised ASRM categories (scores of 1-3, 4 or 5, and 6-15). Model assumptions were checked by inspecting residuals and normal plots. Two-sided P-values $<0.05$ were considered statistically significant. All analyses were performed by using SPSS software, version 8.0 (SPSS, Inc., Chicago, IL). 


\section{Results}

An in ovo photograph of the 14-day CAM containing a silicon ring is presented in figure 1 . The orderly arrangement of the microvessels with ladder-like interdigitation of the arterioles and venules is characteristic of the CAM. Figure 2 shows the angiogenic response of the CAM to peritoneal fluid from a patient with endometriosis; increased density and length of vessels can be seen.

The VDI (median and interquartile ranges [25\%, 75\% percentiles]) of the untreated

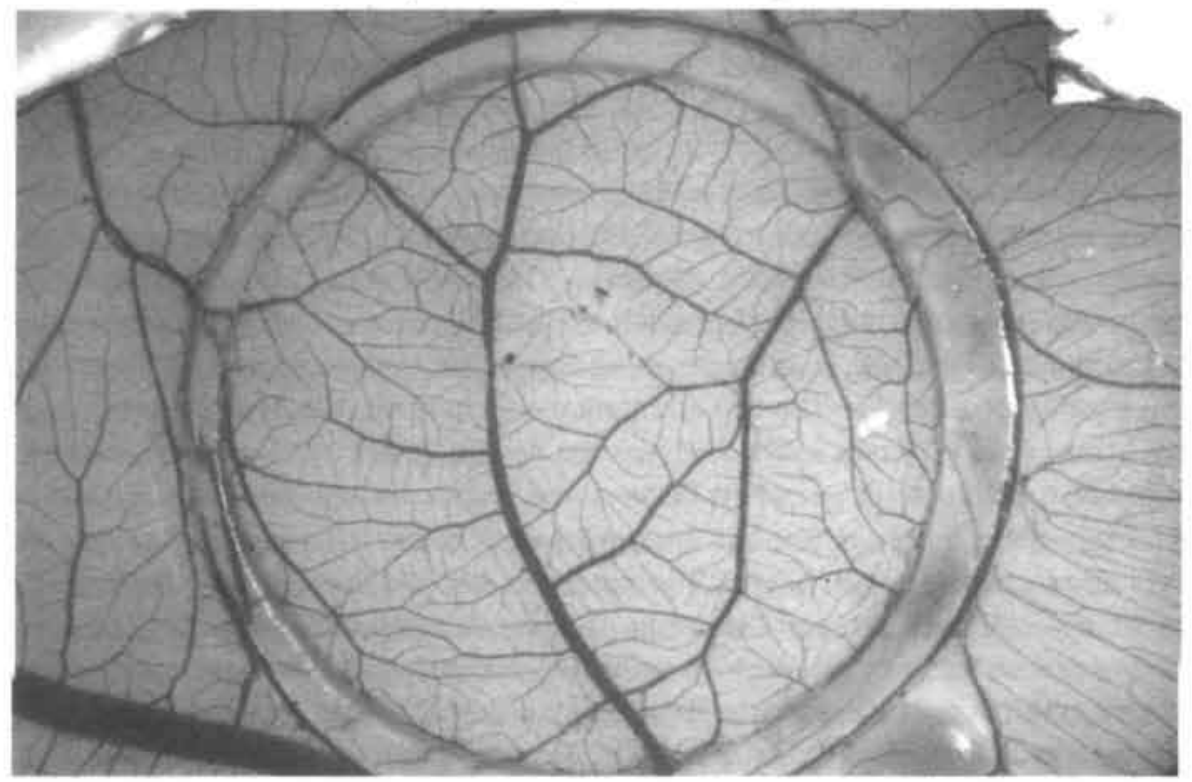

Figure 1 Normal unmanipulated chick embryo chorioallantoic membrane at day 14 . The silicon ring has an inner diameter of $10 \mathrm{~mm}$ (original magnification, x6).

CAM (305, [295, 320]) was similar to that of the CAM on which saline was applied (310, [301, 323]; $\mathrm{P}=0.72)$. Of the 52 peritoneal fluid samples, 8 had a VDI (range of the median VDI, 298.5 - 362) similar to that obtained after applying saline onto the CAM and that of an untreated CAM. Forty-four (85\%) peritoneal fluid samples induced a significantly increased vascular response in the CAM assay. The median VDI of these 44 samples ranged from 341.5 to 481 .

The overall level of $I \mathrm{~L}-1 \beta$ ranged from $0.1-8.7 \mathrm{pg} / \mathrm{ml}$, of $\mathrm{IL}-8$ from $1.5-133.3 \mathrm{pg} / \mathrm{ml}$, of TNF- $\alpha$ from $1.6-17 \mathrm{pg} / \mathrm{ml}$ and of protein from $34-75 \mu \mathrm{g} / \mathrm{ml}$. The first multivariable linear regression analysis focussed on the measurements of these substances in peritoneal fluid. In 35 of the 52 samples, all values were available. Table 1 shows the regression coefficients, $95 \%$ CIs, and P values for TNF- $\alpha, \mathrm{IL}-1 \beta, \mathrm{IL}-8$ and total protein in the analysis of these 35 samples. The concentrations of these factors are plotted against the VDI in figure 3 . Interleukin- 8 and $I L-1 \beta$ appeared to be virtually unrelated to VDI ( $P=0.85$ and $P=0.67$, respectively). Removal of the IL- 8 and IL- $1 \beta$ from the model hardly changed the coefficients for TNF- $\alpha$ and protein. Therefore, the final 


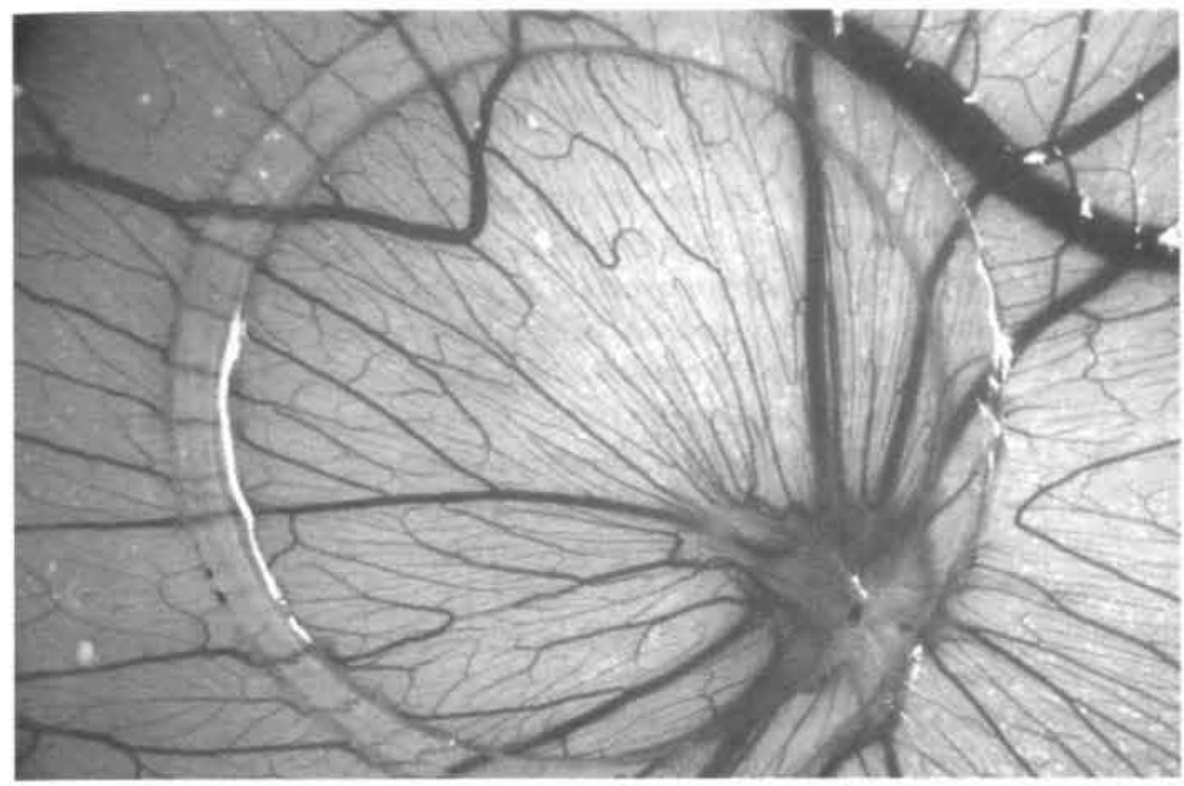

Figure 2 Angiogenic response in chick embryo chorioallantoic membrane assay of peritoneal fluid from a woman with endometriosis. The silicon ring has an inner diameter of $10 \mathrm{~mm}$ (original magnification, x6).

$\begin{aligned} & \text { Table } 1 \text { Multivariable linear regression analysis of laboratory values, with } \\ & \text { median vascular density index as the dependent variable. }\end{aligned}$
$\begin{array}{llll}\text { Compound } & \text { coefficient } & 95 \% \mathrm{Cl} & \text { P value } \\ \text { TNF- } \alpha(\mathrm{pg} / \mathrm{mL}) & 3,46 & 0.18 \text { to } 6.73 & 0,039 \\ \text { Protein }(\mu \mathrm{gg} / \mathrm{mL}) & 1,82 & 0.62 \text { to } 3.01 & 0,004 \\ \text { IL- } 1 \beta(\mathrm{pg} / \mathrm{mL}) & -2,38 & -13.78 \text { to } 9.01 & 0,673 \\ \text { IL-8 }(\mathrm{pg} / \mathrm{mL}) & -1,35 & -15.90 \text { to } 13.19 & 0,851\end{array}$

model included TNF- $\alpha$ and protein only; both of these substances were significantly related to the VDI $(\mathrm{P}=0.039$ and $\mathrm{P}=0.004$, respectively). In the second analysis of all 52 samples, none of the clinical variables -revised ASRM score, phase of menstrual cycle, and type of lesion- were significantly related to the VDI (Table 2). 

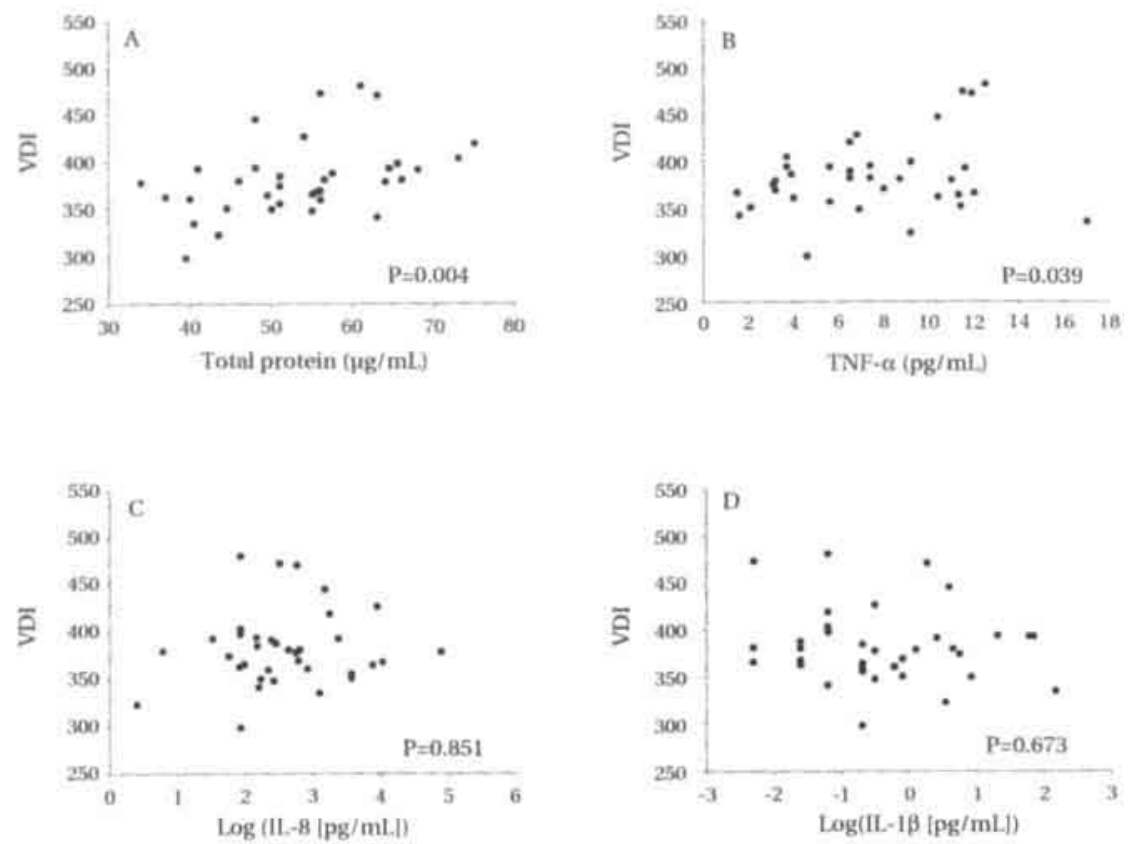

Figure 3 Relation between the concentration of total protein (A), tumor necrosis factor (TNF) - $\alpha$ (B), interleukin (IL)-8 (C), and interleukin (IL) - $1 \beta$ (D) in peritoneal fluid of 35 women with minimal to mild endometriosis and the induced angiogenic response in the chick embryo chorioallantoic membrane model (vascular density index [VDI]).

$\begin{aligned} & \text { Table } 2 \text { Multivariable linear regression analysis of clinical variables, with } \\ & \text { median vascular density index as the dependent variable. }\end{aligned}$
$\begin{array}{lccl} & \\ \text { Clinical variables } & \text { coefficient } & 95 \% \mathrm{Cl} & \text { P value } \\ \text { Rev. ASRM score * } & 6,13 & -18.24 \text { to } 30.49 & 0,615 \\ \text { Rev. ASRM score * } & -11,68 & -46.64 \text { to } 23.28 & 0,505 \\ \text { Type of lesion } & 2,29 & -22.38 \text { to } 26.97 & 0,852 \\ \text { Phase of cycle } & -1,02 & -25.89 \text { to } 23.84 & 0,934\end{array}$

Note: ASRM = American Society for Reproductive Medicine.

- Two dummy variables were used to represent three revised ASRM categories (score 1-3, 4 or 5, and 6-15)

\section{Discussion}

Various recent studies have suggested a determining role of the peritoneal environment in the establishment and maintenance of endometriosis (Oral et al., 1996; Koninckx et al., 1998; Küpker et al., 1998). In particular, it has been suggested that 
superficial endometrial implants are regulated by peritoneal fluid factors (Koninckx et al., 1998). The peritoneal fluid of women with endometriosis has been shown to contain angiogenic and other growth factors, which may contribute to the proliferation of the ectopic endometrium (Ramey and Archer, 1993). To support the hypothesis that local factors are important for the development of endometriosis, Oosterlynck et al. (1993) investigated the presence of angiogenic factors in peritoneal fluid by using the CAM bioassay. They reported a positive angiogenic reaction induced by $58.3 \%$ of the peritoneal fluid samples from women with endometriosis and $12.5 \%$ of the samples obtained from women without endometriosis. This observation was confirmed by Taylor et al. (1997) using an in vitro model of endothelial cell proliferation. Both studies were in agreement with the hypothesis that the angiogenic factors could originate from peritoneal macrophages. Oosterlynck et al. (1993) suggested that TNF- $\alpha$ is a potent macrophage-derived angiogenic factor.

Many investigators have attempted to identify angiogenic factors in the peritoneal fluid that might contribute to the development of endometriosis. However, the complex process of angiogenesis is controlled by an angiogenic switch mechanism, which is triggered by a change in the balance of inducers and inhibitors of angiogenesis (Hanahan and Folkman, 1996). Thus, either an increase in activator concentration or a reduction in inhibitor levels may lead to new vessel growth. Finding a significantly higher level of a given angiogenic factor in peritoneal fluid of women with endometriosis than in women without endometriosis is, in our opinion, insufficient evidence for the involvement of this factor in the pathogenesis of endometriosis. Therefore, we believed that a bioassay should be used to assess the overall angiogenic activity of peritoneal fluid. Subsequently, the association between this angiogenic activity and individual angiogenic factors in the peritoneal fluid should be studied.

In our study, we used the CAM assay, an established bioassay for studying angiogenesis (Auerbach et al., 1991; Knighton et al., 1991; Cockerill et al., 1995; Maas et al., 1999). We demonstrated that the concentration of total protein and TNF- $\alpha$ in the peritoneal fluid was significantly related to the induced angiogenic response in the bioassay. According to the angiogenic switch mechanism, these results suggest that an increase in level of angiogenic proteins, including TNF- $\alpha$, rather than a reduction in level of inhibitors leads to neovascularization. Furthermore, we demonstrated that although $I L-1 \beta$ and IL- 8 were found in increased amounts in the peritoneal fluid of women with endometriosis in other studies, they do not appear to be responsible for the angiogenic response occurring in endometriosis.

Other macrophage-derived factors may be related to the induced angiogenic activity. However, a polyclonal antibody to murine TNF- $\alpha$ can completely neutralize the angiogenic activity in conditioned medium of peritoneal macrophages. This neutralization of activity was demonstrated in the cornea and CAM assay (Leibovich et al., 1987). Because of these findings and the demonstrated association of TNF- $\alpha$ with angiogenic activity in patients with endometriosis in the current study, we suggest that this factor might be an important target for therapeutical interventions in endometriosis. 
In agreement with the studies of Oosterlynck et al. (1993) and Taylor et al. (1997) we found no relation between angiogenic response in the CAM bioassay and phase of the menstrual cycle, revised ASRM score, or type of endometriotic lesion. Apparently, angiogenesis contributes not only to the onset but also to the maintenance of endometriosis. Nisolle et al. (1993) observed higher vascularization and mitotic activity in red lesions than in black lesions. Therefore, we expected to find higher angiogenic activity in peritoneal fluid when active, nonblack lesions were present. Clearly, when endometriotic lesions are present, there is already a disbalance of angiogenic and angiostatic factors in the peritoneal fluid independent of type of lesions or severity of the disease.

In conclusion, our results clearly confirm previous findings of peritoneal fluid angiogenic activity in the peritoneal fluid of women with minimal to mild endometriosis. Moreover, our data indicate involvement of the macrophage-derived angiogenic factor TNF- $\alpha$. Further studies are needed to elucidate whether TNF- $\alpha$ is the primary determining factor of the increased angiogenic activity of peritoneal fluid in endometriosis patients. If this hypothesis is confirmed, blocking angiogenesis (e.g., by anti-TNF- $\alpha$ therapy) may lead to novel approaches for the medical management of endometriosis.

\section{Acknowledgments}

The authors thank Lilian Kessels from the Department of Pharmacology for excellent technical assistance. 


\section{References}

American Society of Reproductive Medicine. (1997) Revised American Society of Reproductive Medicine classification of endometriosis 1996. Fertil. Steril., 67, 817821.

Arici, A., Tazuke, S.I., Attar, E., Kliman, H.J. and Olive D.L. (1996) Interleukin-8 concentration in peritoneal fluid of patients with endometriosis and modulation of interleukin-8 expression in human mesothelial cells. Mol. Hum. Reprod., 2, 40-455.

Auerbach, R., Auerbach, W. and Polakowski, I. (1991) Assays for angiogenesis: a review. Pharmacol. Ther., 51, 1-11.

Cockerill, G.W., Gamble, J.R. and Vadas, M.A. (1995) Angiogenesis: models and modulators. Int. Rev. Cytol., 159, 113-160.

Dunselman, G.A.J., Hendrix, M.G.R., Bouckaert, P.X.J.M. and Evers, J.L.H. (1988) Functional aspects of peritoneal macrophages in endometriosis of women. J. Reprod. Fertil., 82, 707-710.

Eisermann, J., Gast, M.J., Pineda, J., Odem, R.R. and Collins, J.L. (1988) Tumor necrosis factor in peritoneal fluid of women undergoing laparoscopic surgery. Fertil. Steril., 50, 573-579.

Fakih, H., Bagget, B., Holtz, G., Tsang, K., Lee, J.C. and Williamson, H.O. (1987) Interleukin-1: a possible role in the infertility associated with endometriosis. Fertil. Steril., 47, 213-217.

Folkman, J. (1985) Tumor angiogenesis. Adv. Cancer. Res., 43, 175-203.

Folkman, J. (1994) Angiogenesis and breast cancer. J. Clin. Oncol., 12, 441-443.

Fràter-Schröder, M., Risau, W., Hallmann, R., Gautschi, P. and Böhlen, P. (1987) Tumor necrosis factor type $\alpha$, a potent inhibitor of endothelial cell growth in vitro, is angiogenic in vivo. Proc. Natl. Acad. Sci., 84, 5277-5281.

Gazvani, M.R., Christmas, S., Quenby, S., Kirwan, J., Johnson, P.M. and Kingsland, C.R. (1998) Peritoneal fluid concentrations of interleukin-8 in women with endometriosis: relationship to stage of disease. Hum. Reprod., 13, 1957-1961.

Halme, J., Becker, S., Hammond, M.G., Raj, M.H.G. and Raj, S. (1983) Increased activation of pelvic macrophages in infertile women with mild endometriosis. Am. J. Obstet. Gynecol., 145, 333-337.

Halme, J., Becker, S. and Haskill, S. (1987) Altered maturation and function of peritoneal macrophages: Possible role in pathogenesis of endometriosis. Am. J. Obstet. Gynecol., 156, 783-789.

Hanahan, D. and Folkman, J. (1996) Patterns and emerging mechanisms of the angiogenic switch during tumorigenesis. Cell, 86, 353-364.

Iwabe, T., Harada, T., Tsudo, T., Tanikawa, M., Onohara, Y. and Terakawa, N. (1998) Pathogenetic significance of increased levels of interleukin-8 in the peritoneal fluid of patients with endometriosis. Fertil. Steril., 69, 924-930.

Jansen, R.P. and Russell, P. (1986) Nonpigmented endometriosis: clinical, laparoscopic, and pathologic definition. Am. J. Obstet. Gynecol., 155, 1154-1159.

Knighton, D.R., Fiegel, V.D. and Phillips, G.D. (1991) The assay of angiogenesis. Prog. Clin. Biol. Res., 365, 291-299.

Koch, A.E., Polverini, P.J., Kunkel, S.L., Harlow, L.A., DiPietro, L.A. and Elner, V.M. 
(1992) Interleukin-8 as a macrophage-derived mediator of angiogenesis. Science, 258,1798-1801.

Koninckx, P.R., Kennedy, S.H. and Barlow, D.H. (1998) Endometriotic disease: the role of peritoneal fluid. Hum. Reprod. Update, 4, 741-751.

Küpker, W., Schultze-Mosgau, A. and Diedrich, K. (1998) Paracrine changes in the peritoneal environment of women with endometriosis. Hum. Reprod. Update, 4, $719-$ 723.

Leibovich, S.J., Polverini, P.J., Shepard, H.M., Wiseman, D.M., Shively, V. and Nuseir, N. (1987) Macrophage-induced angiogenesis is mediated by tumour necrosis factor$\alpha$. Nature, 329, 630-632.

Lowry, O.H., Rosebrough, N.J., Farr, A.L. and Randall, R.J. (1951) Protein measurements with the Folin phenol reagent. J. Biol. Chem., 193, 265-275.

Maas, J.W.M., Le Noble, F.A.C., Dunselman, G.A.J., de Goeij, A.F.P.M., Struijker Boudier, H.A.J. and Evers, J.L.H. (1999) The chick embryo chorioallantoic membrane as a model to investigate the angiogenic properties of human endometrium. Gynecol. Obstet. Invest., 48, 108-112.

Mori, H., Sawairi, M., Nakagawa, M., Itoh, N., Wada, K. and Tamaya, T. (1992) Expression of interleukin-1 (IL-1) beta messenger ribonucleic acid (mRNA) and IL-1 receptor antagonist mRNA in peritoneal macrophages from patients with endometriosis. Fertil. Steril., 57, 535-542.

Nisolle, M., Casanas-Roux, E, Anaf, V., Mine, J. and Donnez, J. (1993) Morphometric study of the stromal vascularization in peritoneal endometriosis. Fertil. Steril., 59, 681-684.

Noyes, R.W., Hertig, A.T. and Rock, J. (1950) Dating the endometrial biopsy. Fertil. Steril., 1, 3-25.

Oosterlynck, D.J., Meuleman, C., Sobis, H., Vandeputte, M. and Koninckx, P.R. (1993) Angiogenic activity of peritoneal fluid from women with endometriosis. Fertil. Steril., 59, 778-782.

Oral, E., Olive, D.L. and Arici, A. (1996) The peritoneal environment in endometriosis. Hum. Reprod. Update, 2, 385-398.

Overton, C., Fernandez-Shaw, S., Hicks, B., Barlow, D. and Starkey, P. (1996) Peritoneal fluid cytokines and the relationship with endometriosis and pain. Hum. Reprod., 11, 380-386.

Polverini, PJ., Cotran, R.S., Gimbrone, M.A. and Unanue, E.R. (1977) Activated macrophages induce vascular proliferation. Nature, 269, 804-806.

Ramey, J.W. and Archer, D.F. (1993) Peritoneal fluid: its relevance to the development of endometriosis. Fertil. Steril., 60, 1-14.

Ryan, I.P., Tseng, J.F., Schriock, E.D., Khorram, O.K., Landers, D.V. and Taylor, R,N. (1995) Interleukin-8 concentrations are elevated in peritoneal fluid of women with endometriosis. Fertil. Steril., 63, 929-932.

Sampson, J.A. (1940) The development of the implantation theory for the origin of peritoneal endometriosis. Am. J. Obstet. Gynecol., 40, 549-557.

Sunderkötter, C., Steinbrink, K., Goebeler, M., Bhardwaj, R. and Sorg, C. (1994) Macrophages and angiogenesis. J. Leukoc. Biol., 55, 410-422. 
Taketani, Y., Kuo, T. and Mizuno, M. (1992) Comparison of cytokine levels and embryo toxicity in peritoneal fluid in infertile women with untreated or treated endometriosis. Am. J. Obstet. Gynecol., 167, 265-270.

Taylor, R.N., Ryan, I.P., Moore, E.S., Hornung, D., Shifren, J.L. and Tseng, J.F (1997) Angiogenesis and macrophage activation in endometriosis. Ann. N. Y. Acad. Sci., 828, 194-207. 


\section{Chapter 8}

General discussion

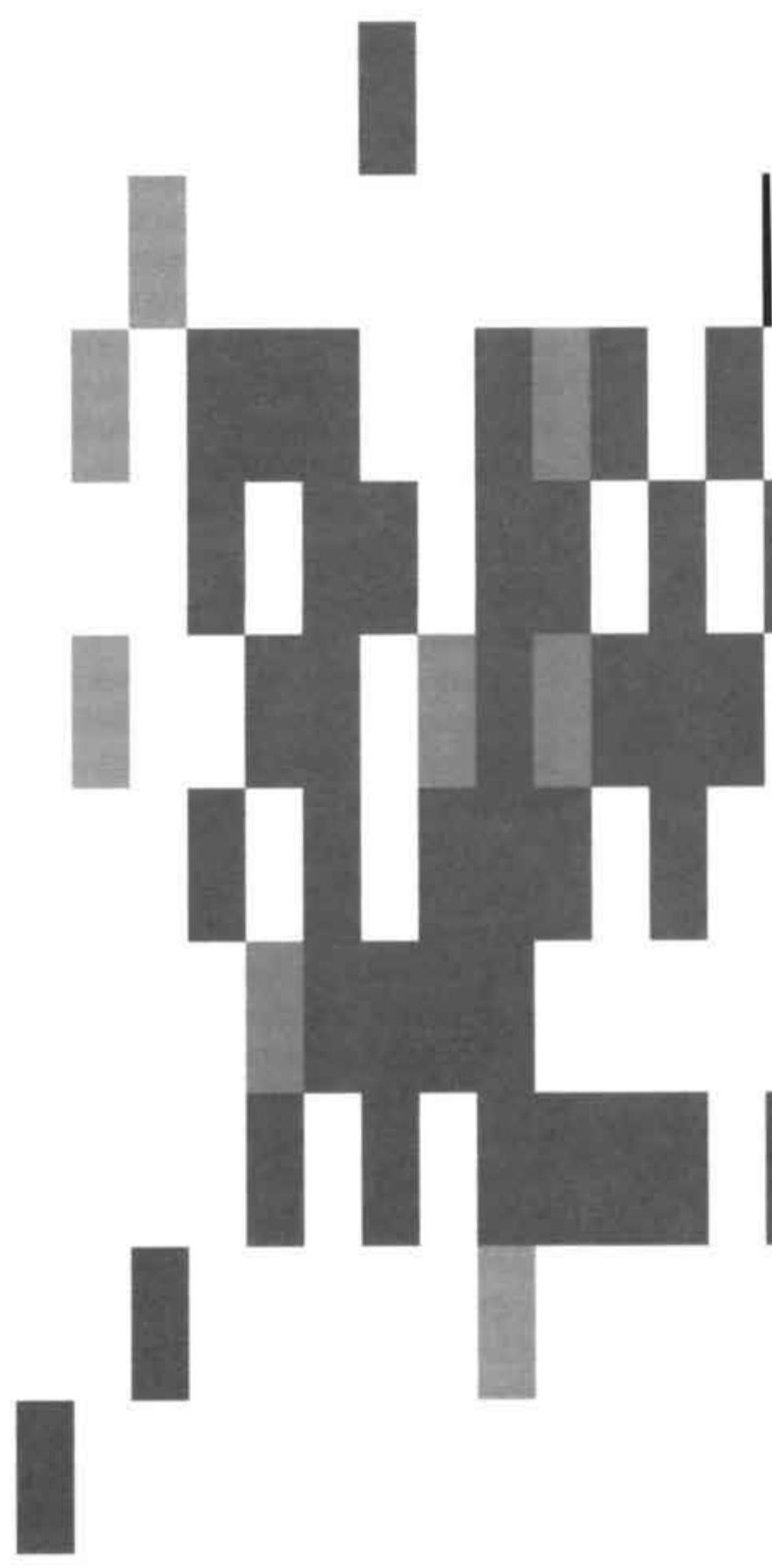


The initial phase of endometriosis development, according to the transplantation theory, consists of retrograde seeding of viable endometrial fragments, adhesion of these fragments to the mesothelial lining of the peritoneal cavity, invasion and subsequent rescue of the re-proliferating tissue by angiogenesis from the host tissue. In this thesis the latter two phases, invasion and angiogenesis, were studied. It was demonstrated that endometrial stromal cells and intact glandular structures were invasive. Moreover, endometrial fragments induced an angiogenic response in the CAM model. Before dealing with the major conclusions from this work, the experimental approach to reach these conclusions is discussed.

\section{The chick embryo chorioallantoic membrane}

The chick embryo chorioallantoic membrane (CAM) was evaluated as a model to study both the invasive character and angiogenic potential of human endometrium. So far, the CAM has mainly been used for assaying these events for several types of neoplasms. We first tested the validity of the CAM model and the methods which were applied for the studies with endometrial tissue. Suspensions of ECC-1 cells, an established epithelial cell line derived from an adenocarcinoma of human endometrial origin, were explanted onto the CAM. The ability of cells to traverse the chorionic epithelium (CE) and to establish contact with the mesenchymal layer was used as an end point for invasion. Indeed, after 5 days clusters of endometrial ECC-1 cells could be found inside the mesenchymal layer of the CAM. This confirmed the validity of this model to study the invasive potential of endometrial cells after explantation of cell suspensions.

Furthermore, we have assessed the suitability of the CAM assay to quantitate an angiogenic response. Quantitation of this angiogenesis assay was initially done by subjectively scoring the extent of vascularization on a graded scale (Vu et al., 1985). However, with this method it is very difficult to compare results with the aid of statistical analysis. Therefore, a vascular density index (VDI), an objective estimate of vessel number and length, is used for the in vivo CAM situation. A computerized image analysis system was applied to count the vessels. Our intra-observer variability of $5.2 \%$ compared favorably to those obtained by previous investigators. The CAM assay appeared to be a suitable model for investigating the angiogenic potential of endometrium and our method allows reliable and reproducible quantitation of the angiogenic response.

\section{Invasion}

The CAM invasion assay was used to obtain more insight in the events that occur after the adhesion of endometrial cells to the peritoneum. Preferably, retrogradely shed menstrual tissue should be used for these experimental studies, but this material is difficult to obtain in sufficiently large amounts for use in experiments as ours. Therefore, we used endometrial tissue isolated from antegradely shed menstrual effluent. Various integrins (Koks et al., 2000a) and matrix metalloproteinases (MMPs) (Koks et al., 2000b) are expressed in this menstrual endometrium tissue. These integrins have been shown to be involved in adhesion of epithelial cells to extracellular 
matrix components and the MMPs might contribute to the potential of endometrial cells to invade by degrading the extracellular matrix. In our study invasion could not be observed when cell suspensions of antegradely shed menstrual effluent were explanted onto the CAM. Likewise, invasion of single cytokeratin-positive epithelial cells obtained from biopsied cyclic endometrium did not occur. In contrast, stromal cells and intact epithelial glandular structures were invasive. An explanation for the inability of the menstrual cells to invade the CAM might be that the antegradely shed cells are not viable enough anymore. In an earlier study it was demonstrated that after 5 days of culture of cells, obtained from antegradely shed menstrual effluent, vimentin- and cytokeratin-positive cells were identified in 10 out of 17 cases. This proved the viability of a part of the menstrual effluent cells (Koks et al., 1997). On the other hand, a substantial part of the antegradely shed menstrual effluent is apparently non-viable, and therefore unable to invade the CAM. In vivo, the shed menstrual cells that reach the abdominal cavity may preserve their viability, and are presumably exposed to peritoneal environmental factors, such as hormones and growth factors.

Besides viability, the structural architecture of the antegradely shed menstrual tissue may differ from the endometrial tissue in the peritoneal fluid that adheres to the peritoneum, invades and develops into an endometriotic lesion. Endometrial tissue, which reaches the abdominal cavity, is presumably degraded by factors in the peritoneal fluid, resulting in single cells rather than glandular structures (Van der Linden et al., 1995). It has been demonstrated (Van der Linden et al., 1998) that single endometrial cells, in contrast to endometrial fragments, do not adhere to amniotic membranes and do not show expression of cell adhesion molecules. In the present study it is confirmed that single epithelial cells are not invasive.

Our findings in the in vivo CAM assay are also in agreement with the results of Gaetje and coworkers (1997), who used an in vitro collagen invasion assay. The finding that intact glandular structures are invasive, strongly suggests that the structural organization of the tissue is not only a critical factor in facilitating adhesive but also in invasive behaviour. To substantiate these proposed explanations, endometrial fragments obtained from different phases of the menstrual cycle were explanted onto the CAM. These fragments of $1.5 \times 2 \mathrm{~mm}$ consist of a large number of viable glands and stromal cells. Again invasion of both stromal cells and intact endometrial glands into the mesenchymal layer was observed, but never invasion of single epithelial cells. Moreover, three days after explantation, endometriosis-like lesions, which consisted of human endometrial glands and stromal cells, were observed in the mesenchymal layer of the chick embryo CAM. Thus, when a sufficient amount of viable, intact glandular structures and/or stromal cells adhere to the peritoneal lining, invasion occurs and endometriotic lesions develop.

\section{' Angiogenesis}

In our invasion experiments CAM vessels, containing nucleated chick erythrocytes, were occasionally observed in the endometriosis-like lesions. It seems that after invasion, in order to be able to survive and even proliferate, endometrial cells receive new 
blood supply from the surrounding host tissue. It has been postulated previously that angiogenesis, the formation of new blood vessels, may play a critical role in the pathogenesis of endometriosis. For instance, at laparoscopy it is often observed that most of the typical endometriotic lesions are surrounded by a hypervascularized area. Furthermore, the peritoneal fluid from women with endometriosis is more angiogenic than from women without the disease. This has been observed in both the CAM angiogenesis assay and an in vitro model of endothelial cell proliferation (Oosterlynck et al., 1993; Taylor et al., 1997). However, the origin of the increased concentration of angiogenic factors in the peritoneal fluid is still not clear. Macrophages and endometriosis implants are both suggested to be likely sources. We demonstrated, using the CAM angiogenesis assay, that human endometrium itself is angiogenic throughout the menstrual cycle. This angiogenic potential shows a cyclic variation with a nadir in the late proliferative phase and significantly higher levels in the other phases. Our findings are in agreement with other studies, which report maximum levels of VEGF mRNA expression in the glands and VEGF immunostaining in the stroma in the late secretory and menstrual phase (Charnock-Jones et al., 1993; Shifren et al., 1996; Torry et al., 1996; Gargett et al. 1999). When this highly angiogenic endometrium tissue reaches the peritoneal cavity during menstruation, it is an additional source of the angiogenic factors, besides those produced by activated macrophages, in the peritoneal fluid. If these endometrial fragments adhere to the peritoneal lining and invade, they may be well able to induce their own blood supply from existing peritoneal host vessels.

Many investigators have attempted to identify angiogenic factors in the peritoneal fluid, which might contribute to the development of endometriosis. However, either an increase in concentration of angiogenic factors, or a reduction in inhibitor levels may lead to new vessel growth. Finding a significantly increased level of a given angiogenic factor in peritoneal fluid of women with endometriosis as compared to women without endometriosis is, in our opinion, insufficient evidence for the involvement of this factor in the pathogenesis of endometriosis. A bioassay has to be used to assess the overall angiogenic activity of peritoneal fluid, and subsequently the association between this activity and individual angiogenic and/or angiostatic factors in the peritoneal fluid can be studied. Accordingly, the concentration of TNF- $\alpha$ in the peritoneal fluid was demonstrated to be significantly related to the induced angiogenic response in the CAM bioassay. Furthermore, $\mathrm{IL}-1 \beta$ and $\mathrm{IL}-8$, although found in increased concentrations in the peritoneal fluid of women with endometriosis in other studies, do not appear to be responsible for the angiogenic response occurring in endometriosis. Obviously, also other factors, presumably macrophagederived, might be related to the induced angiogenic activity. It has been demonstrated in the CAM assay however that a polyclonal antibody to murine TNF- $\alpha$ can completely neutralize the angiogenic activity in conditioned medium of peritoneal 102 macrophages (Leibovich et al., 1987). Considering this finding and the demonstrated association of TNF- $\alpha$ with the angiogenic activity in patients with endometriosis in the present study, we suggest that this factor might be a relevant target for future therapeutical interventions in endometriosis. 
The results of the present study contribute to refining the transplantation theory and, consequently, to a better understanding of the pathogenesis of endometriosis. Under normal conditions retrogradely shed menstrual tissue fragments are degraded into single cells. If this mechanism fails or when the amount of regurgitated tissue is too large, a considerable number of viable endometrial fragments may remain to adhere to the peritoneum. Contact between fragments and the submesothelial layer is established, either by the presence of a pre-existing lesion in the peritoneal lining, or by active damaging of the mesothelium by the endometrial cells. Subsequently, intact glandular structures surrounded by stromal cells invade the extracellular matrix. These invading cells induce angiogenesis, and, therefore, provide their own blood supply for further outgrowth and development into a clinically recognizable endometriotic lesion. The peritoneal environment may support these events by providing hormones, growth and angiogenic factors to preserve the viability of the regurgitated endometrial cells and to allow maintenance and progression of the established endometriotic lesions.

\section{Future perspectives}

A model has been established which can be used to study the events that mimic the early pathogenesis of endometriosis, including invasion of endometrial cells, angiogenesis, and the establishment of endometriosis-like lesions. This provides several interesting opportunities for future studies.

In contrast to stromal cells and epithelial glands from biopsied cyclic endometrium, antegradely shed endometrial cells did not invade in this in vivo CAM model. This has to be confirmed in an in vitro collagen invasion assay. Starzinski-Powitz and coworkers (1998) showed that the invasive capacity of endometriotic cells, but not eutopic endometrial cells, was considerably enhanced by adding of peritoneal fluid to the culture medium. It will be interesting to find out whether menstrual cells will become invasive after addition of peritoneal fluid onto the CAM. Another possibility is to culture the menstrual cells in medium with peritoneal fluid before grafting it onto the CAM. When the cells become invasive, gene products can be identified, which are associated with the invasive properties. In addition, the invasive capacity of menstrual cells from women with versus without endometriosis has to be compared.

We demonstrated that the endometriosis-like lesions in the CAM consist of human endometrial glands and stromal cells. These lesions, the vasculature and the surrounding area have to be characterized more thoroughly.

Since the development of new blood vessels is a prerequisite for further outgrowth of the invaded cells, studies on blocking angiogenesis are of therapeutical importance. Most of the potential anti-angiogenic therapies have focussed on tumor angiogenesis, but they may also be useful for treatment of endometriosis. In our study angiogenesis induced by endometrium tissue showed a similar cyclic pattern as VEGF mRNA expression in the glands and VEGF immunostaining in the stroma. Furthermore, the angiogenic response in the CAM induced by peritoneal fluid of patients with endometriosis was significantly related to the concentration of TNF- $\alpha$ in that fluid. Therefore, VEGF and TNF- $\alpha$ may be important targets for anti-angiogenic therapy in endo- 
metriosis. Control of the bioavailability of VEGF may be achieved by capture of VEGF by soluble receptors, or specific neutralizing anti-VEGF antibodies (McLaren, 2000). Anti-TNF- $\alpha$ antibodies have already been proven to be effective in the treatment of angiogenesis-dependent diseases, such as rheumatoid arthritis and Crohn's disease (Camussi and Lupia, 1998; Mikula, 1999). The efficacy of these approaches in endometriosis related angiogenesis remains to be established.

Angiogenesis shares many functional characteristics with invasion, including the requirement for expression of the invasive phenotype and associated attachment and proteolytic activity. Integrins and matrix metalloproteinases may therefore be potential targets for pharmacological interventions. A monoclonal antibody to integrin $\alpha_{v} \beta_{3}$ disrupts ongoing angiogenesis on the CAM (Brooks et al., 1994). It has been demonstrated that blocking of metalloproteinase activity with TIMP-1 inhibited the formation of endometriotic lesions in athymic nude mice (Bruner et al., 1997). It would be interesting to find out whether anti- $\alpha_{v} \beta_{3}$ antibody or TIMP prevent invasion of endometrial cells and/or the angiogenic response to endometrium in the CAM assay.

Another approach may be gene therapy or immunotherapy. Gene therapy is a concept of correcting the symptoms of disease by the delivery of genes whose expression limits the impact of the disease. In immunotherapy immune effector cells are used to direct their cytolytic activity specifically towards the harmful cells. It is possible to target the endometriotic cells directly, or, alternatively, the vasculature in the endometriotic lesions. The most significant problem is that the gene or the immune effector cell must be delivered to the right place to correct the disorder without causing sideeffects in other parts of the body. Therefore, in order to target the endometriotic cells or the endothelial cells of the newly formed vessels in the endometriotic lesion, cell specific antigens have to be identified. 


\section{References}

Bruner, K.L., Matrisian, L.M., Rodgers, W.H., Gorstein, E and Osteen, K.G. (1997) Suppression of matrix metalloproteinases inhibits establishment of ectopic lesions by human endometrium in nude mice. J. Clin. Invest., 99, 2851-2857.

Brooks, P.C., Montgomery, A.M., Rosenfeld, M., Reisfeld, R.A., Hu, T., Klier, G. and Cheresh, D.A. (1994) Integrin alpha $v$ beta 3 antagonists promote tumor regression by inducing apoptosis of angiogenic blood vessels. Cell, 79, 1157-1164.

Camussi, G. and Lupia, E. (1998) The future role of anti-tumour necrosis factor (TNF) products in the treatment of rheumatoid arthritis. Drugs, 55, 613-620.

Charnock-Jones, D.S., Sharkey, A.M., Rajput-Williams, J., Burch, D., Schofield, J.P., Fountain, S.A., Boocock, C.A. and Smith, S.K. (1993) Identification and localization of alternately spliced mRNAs for Vascular Endothelial Growth Factor in human uterus and estrogen regulation in endometrial carcinoma cell lines. Biol. Reprod., 48, 1120-1128.

Gaetje, R., Kotzian, S., Herrmann, G., Baumann,R. and Starzinski-Powitz, A. (1997) Nonmalignant epithelial cells, potentially invasive in human endometriosis, lack the tumor suppressor molecule E-cadherin. Am. J. Pathol., 150, 461-467.

Gargett, C.E., Lederman, F.L, Lau, T.M., Taylor, N.H. and Rogers, P.A.W. (1999) Lack of correlation between vascular endothelial growth factor production and endothelial cell proliferation in the human endometrium. Hum. Reprod., 14, 2080-2088.

Koks, C.A.M., Dunselman, G.A.J., de Goeij, A.F.P.M., Evers, J.L.H. and Arends, J.W. (1997) Evaluation of a menstrual cup to collect shed endometrium for in vitro studies. Fertil. Steril., 68, 560-564.

Koks, C.A.M., Groothuis, P.G., Dunselman, G.A.J., de Goeij, A.F.P.M. and Evers, J.L.H. (2000a) Adhesion of menstrual endometrium to extracellular matrix: the possible role of integrin $\alpha_{6} \beta_{1}$ and laminin interaction. Mol. Hum. Reprod., 6, 170-177.

Koks, C.A.M., Groothuis, P.G., Slaats, P., Dunselman, G.A.J., de Goeij, A.F.P.M. and Evers, J.L.H. (2000b) Matrix metalloproteinases and their tissue inhibitors in antegradely shed menstruum and peritoneal fluid. Fertil. Steril., 73, 604-612.

Leibovich, S.J., Polverini, P.J., Shepard, H.M., Wiseman, D.M., Shively, V. and Nuseir, N. (1987) Macrophage-induced angiogenesis is mediated by tumour necrosis factor$\alpha$. Nature, 329, 630-632.

McLaren, J. (2000) Vascular endothelial growth factor and endometriotic angiogenesis. Hum. Reprod. Update, 6, 45-55.

Mikula, C.A. (1999) Anti-TNF alpha: new therapy for Crohn's disease. Gastroenterol. Nurs., 22, 245-248.

Oosterlynck, D.J., Meuleman, C., Sobis, H., Vandeputte, M. and Koninckx, P.R. (1993) Angiogenic activity of peritoneal fluid from women with endometriosis. Fertil. Steril., 59, 778-782.

Shifren, J.L., Tseng, J.F., Zaloudek, C.J., Ryan, I.P., Meng, Y.G., Ferrara, N., Jaffe, R.B. and Taylor, R.N. (1996) Ovarian steroid regulation of vascular endothelial growth factor in the human endometrium: implications for angiogenesis during the menstrual cycle and in the pathogenesis of endometriosis. J. Clin. Endocrinol. Metab., 81, 31123118. 
Starzinski-Powitz, A., Gaetje, R., Zeitvogel, A., Kotzian, S., Handrow-Metzmacher, H., Herrmann, G., Fanning, E. and Baumann, R. (1998) Tracing cellular and molecular mechanisms involved in endometriosis. Hum. Reprod. Update, 4, 724-729.

Taylor, R.N., Ryan, I.P., Moore, E.S., Hornung, D., Shifren, J.L. and Tseng, J.F. (1997) Angiogenesis and macrophage activation in endometriosis. Ann. N. Y. Acad. Sci., 828, 194-207.

Torry, D.S., Holt, V.J., Keenan, J.A., Harris, G., Caudle, M.R. and Torry, R.J. (1996) Vascular endothelial growth factor expression in cycling human endometrium. Fertil. Steril., 66, 72-80.

Van der Linden, PJ.Q., Dunselman, G.A.J., de Goeij, A.F.P.M., Van der Linden,E.P.M., Evers, J.L.H. and Ramaekers, F.C.S. (1995) Epithelial cells in peritoneal fluid: of endometrial origin? Am. J. Obstet. Gynecol., 173, 566-570.

Van der Linden, PJ.Q., de Goeij, A.F.P.M., Dunselman, G.A.J., Erkens, H.W.H. and Evers, J.L.H. (1998) Amniotic membrane as an in vitro model for endometrium-extracellular matrix interactions. Gynecol. Obstet. Invest., 45, 7-11.

Vu, M.T., Smith, C.F., Burger, P.C. and Klintworth, G.K. (1985) An evaluation of methods to quantitate the chick chorioallantoic membrane assay in angiogenesis. Lab. Invest., 53, 499-508. 


\section{Summary/ Samenvatting}

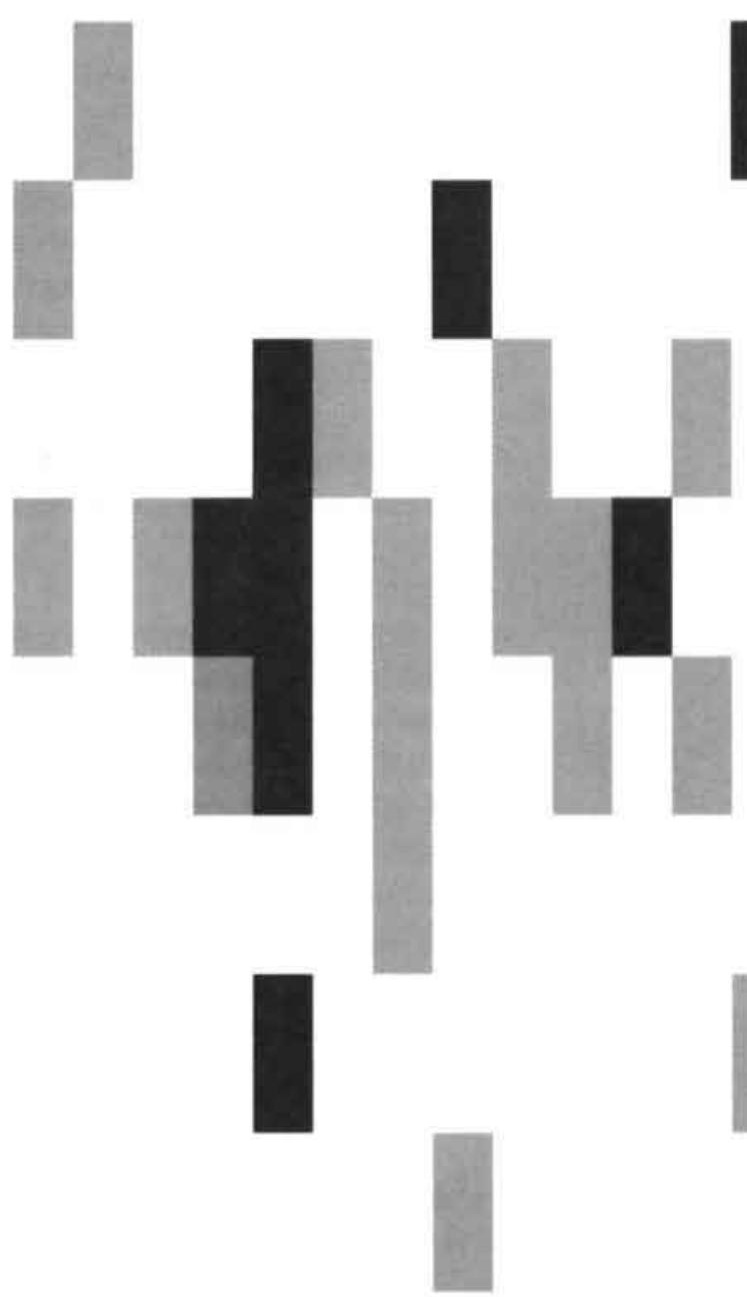




\section{S Summary}

Endometriosis is the presence of tissue with epithelial and stromal characteristics of endometrium outside the uterine cavity. The implantation theory on the pathogenesis of endometriosis is widely accepted. It presumes retrograde transportation of viable endometrial cells during menstruation, adhesion of these cells onto the peritoneum, with subsequent implantation and proliferation. Research has been focussed, so far, on identifying viable endometrial cells in peritoneal fluid and adhesive potential of endometrial cells to the peritoneal lining. It is still not clear what occurs between retrograde seeding of endometrial cells and the clinical recognition of endometriotic lesions.

Implantation may require, besides adhesion, also invasion of endometrial cells and from that stage onwards these cells will depend on the formation of new blood vessels, angiogenesis, for further outgrowth and development into an endometriotic lesion.

In chapter 1 the current concepts on invasion and angiogenesis, in general as well as with regard to normal endometrium and endometriosis, are described. Because both invasion and angiogenesis are studied with the chick embryo chorioallantoic membrane (CAM), this model is explained in detail, including its history and applications. The aims of this thesis are stated in chapter 2 :

- to assess the invasive and angiogenic potential of endometrial cells;

- to investigate whether endometriosis-like lesions can be formed in the CAM model;

- to assess the angiogenic activity of peritoneal fluid of patients with endometriosis and to identify an associated angiogenic factor.

In chapter 3 the invasive potential of endometrial cells is studied using the CAM model. Suspensions of endometrium carcinoma (ECC-1) cells, menstrual effluent cells, or glandular structures and/or stromal cells obtained from endometrial biopsies were explanted onto the CAM. The explants including the surrounding CAM were excised at daily intervals and analyzed using immunohistochemistry. ECC-1 cells were invasive and could be found in the mesenchymal layer at 5 days after explantation, which validated the CAM model and our methods to study invasion. Both endometrial epithelial glandular structures and stromal cells, but not single epithelial or shed menstrual cells, were invasive in the CAM model. We suggest that number, viability and structural integrity of endometrial glandular structures surrounded by stromal cells in the peritoneal cavity are important factors in the development of endometriosis.

In chapter 4 endometrial fragments, consisting of glands and stromal cells, are explanted onto the CAM. The grafts including the surrounding CAM were excised at 24 , 48 or 72 hours after explantation, fixed and embedded in paraffin for immunohistochemistry and in situ hybridization (ISH). After 24 hours of incubation, direct contact between endometrial stromal as well as epithelial cells of the explant and the mesenchymal layer of the CAM was observed. Invasion of both stromal cells and intact 
endometrial glands into the mesenchymal layer was observed after 48 hours. At 72 hours, endometriosis-like lesions, which consisted of dilated glands and stromal cells, were observed in the mesenchymal layer. In the lesions the epithelial and stromal cells showed ISH-signals specific for human chromosome 1, confirming their human origin. In conclusion, after 3 days of incubation, endometriosis-like lesions consisting of human endometrial glands and stromal cells, are found in the mesenchymal layer of the CAM. These lesions apparently result from the invasion of intact human epithelial structures and stromal cells.

In chapter 5 an objective method of quantitation of the vascular response of the CAM to endometrium tissue is developed. Samples of proliferative endometrium and control mouse skin tissue were explanted onto the CAM. Additional controls consisted of normal unmanipulated CAM. Four days after grafting, photographs of the explant and the surrounding area were taken in ovo to measure the vascular density index (VDI). The VDI is a stereological estimate of vessel number and length, which was obtained by counting the intersections of vessels with a circular grid superimposed on a computerized image. Endometrium tissue caused a significant increase in VDI as compared to the controls. The intra-observer variability was $5.2 \%$. This study demonstrates that the CAM assay is a suitable model to assess the angiogenic properties of endometrium. Furthermore, our method allows detailed quantitation of the vascular response in an objective and reproducible way.

In chapter 6 the method, as described in chapter five, is used to assess the angiogenic potential of endometrium obtained at different phases of the menstrual cycle. Endometrium tissue, independent of the phase of the menstrual cycle, caused a significant increase in VDI as compared to the negative controls. There was a significant difference in angiogenic response between the phases of the menstrual cycle. The VDIs of the early proliferative, early secretory and late secretory phase were significantly higher than the VDI of the late proliferative phase. Evidently, human endometrium is angiogenic throughout the menstrual cycle and shows cyclic variation. It was suggested that elongation of existing vessels during the early proliferative phase as well as growth and coiling of the spiral vessels during the secretory phase may demand for higher angiogenic activity than outgrowth and maintenance of vessels during the late proliferative phase.

In chapter 7 the angiogenic activity of peritoneal fluid from 52 women with minimal to mild endometriosis is determined. Subsequently, the relationship between this angiogenic activity and the concentration of some angiogenic factors or clinical variables, such as phase of menstrual cycle, type of lesion and rASRM classification of endometriosis was investigated. Eighty-five percent of the peritoneal fluid samples induced angiogenesis in the CAM bioassay. TNF- $\alpha$ and total protein were significantly related to the VDI, whereas $\mathrm{IL}-1 \beta, \mathrm{IL}-8$ and the clinical variables appeared not to affect the angiogenic response. This study clearly confirms previous findings of peritoneal fluid angiogenic activity in women with minimal to mild endometriosis and indicates the involvement of TNF- $\alpha$. 
In chapter 8 the results of the studies are discussed and some future perspectives are given. It has been demonstrated that endometrial cells have invasive as well as angiogenic potential, moreover, we have been able to establish endometriosis-like lesions in the CAM model. Future research should be focussed on the identification of gene products, which are associated with the invasive properties. Furthermore, since the development of new blood vessels is a prerequisite for further outgrowth of the invaded cells into an endometriotic lesion, studies on blocking angiogenesis are of therapeutical importance. Another approach may be gene therapy or immunotherapy, for which first specific endometriotic and/or endothelial cell markers have to be identified. 


\section{" Samenvatting}

Endometriose is de aanwezigheid van endometrium epitheel- en stromacellen buiten de baarmoederholte. De meest geaccepteerde theorie om de pathogenese van endometriose te verklaren is de implantatietheorie. Deze theorie veronderstelt retrograde menstruatie van vitale endometriumcellen via de tubae naar de buikholte, hechting van deze cellen aan het peritoneum gevolgd door implantatie en proliferatie. Tot nu toe is onderzoek gericht geweest op de identificatie van endometriumcellen in peritoneumvloeistof en het vermogen van endometriumcellen zich te hechten aan het peritoneum. Het is echter niet duidelijk welke stappen er plaatsvinden tussen het moment van aanhechting en de aanwezigheid van endometriosehaarden.

Voorafgaande aan implantatie moet adhesie en invasie van endometriumcellen hebben plaatsgevonden. Deze geïnvadeerde cellen zullen voor de ontwikkeling tot een endometriosehaard afhankelijk zijn van de vorming van nieuwe vaten, een proces dat angiogenese wordt genoemd.

In hoofdstuk 1 worden de huidige inzichten ten aanzien van invasie en angiogenese beschreven, zowel in het algemeen als gerelateerd aan endometrium en endometriose. Invasie en angiogenese kunnen beide bestudeerd worden met behulp van het chorio-allantois membraan (CAM) van het kippenembryo. Het CAM-model wordt uitgebreid besproken, waarbij wordt ingegaan op ontwikkelingen en actuele toepassingen.

In hoofdstuk 2 worden de doelstellingen van dit proefschrift uiteengezet:

- bestuderen van de invasieve en angiogene eigenschappen van endometriumcellen; - onderzoeken of endometriose-achtige haarden gevormd kunnen worden in het CAM;

- bepalen van de angiogene activiteit in peritoneumvloeistof van vrouwen met endometriose en de hiervoor verantwoordelijke angiogene factoren identificeren.

In hoofdstuk 3 worden met behulp van het CAM-model de invasieve eigenschappen van endometriumcellen bestudeerd. Hiervoor werden op het CAM suspensies aangebracht van endometrium carcinoomcellen (ECC-1), van cellen uit menstruatievocht en van klierbuizen en/of stromale cellen, verkregen van endometriumbiopten. $\mathrm{Na}$ incubatie werd dit gebied uitgesneden en met behulp van immunohistochemie geanalyseerd. ECC-1 cellen invadeerden het CAM, wat de geschiktheid van dit model voor het bestuderen van invasie bevestigde. Intacte klierbuizen en stromale cellen bleken invasief, in tegenstelling tot cellen uit menstruatievocht en losse epitheelcellen. We veronderstellen dat het aantal, de vitaliteit en het intact zijn van door stromale cellen omgeven klierbuizen in de peritoneumvloeistof, belangrijke factoren zijn in de pathogenese van endometriose.

In hoofdstuk 4 hebben we derhalve endometriumfragmenten, bestaand uit grote aantallen klierbuizen en stromale cellen, op het CAM geplaatst. Dit gedeelte van het CAM werd 24, 48 of 72 uur later uitgesneden, gefixeerd en ingebed in paraffine voor immunohistochemie en in situ hybridisatie (ISH). Na 24 uur bestond er direct con- 
tact tussen zowel stromale als epitheliale cellen van het endometriumfragment met de mesenchymale laag van het CAM. Na 48 uur vond er invasie in het mesenchym plaats van stromale cellen en intacte klierbuizen. Na 72 uur troffen we endometriose-achtige haarden aan in de mesenchymale laag van het CAM. Deze haarden bevatten verwijde epitheliale buizen en stromale cellen, die positieve ISH-signalen lieten zien voor humaan chromosoom 1. Dit bevestigde de humane afkomst van deze haarden in het CAM. Drie dagen na het aanbrengen van endometriumfragmenten op het CAM worden er dus endometriose-achtige haarden, bestaande uit humane klierbuizen en stromale cellen, aangetroffen in het mesenchym. Deze haarden ontstaan naar alle waarschijnlijkheid door invasie van intacte humane klierbuisstructuren en stromale cellen.

In hoofdstuk 5 worden de door ons ontwikkelde objectieve kwantificatie van de angiogene reactie op endometriumweefsel beschreven. Fragmenten van proliferatief endometrium en - als controlemateriaal - stukjes huid van een muis werden op het CAM gelegd. Vier dagen na het opbrengen van het weefsel werden er dia's gemaakt in ovo van het gebied rondom het weefsel. De dia werd ingelezen in de computer waarna er een grid met concentrische cirkels over de ingelezen dia werd geplaatst. Het aantal doorkruisingen van de bloedvaten met de binnenste vijf cirkels werd geteld. Op deze manier werd de Vascular Density Index (VDI) verkregen, een maat voor het aantal en de lengte van de vaten. Endometrium induceerde een significante stijging van de VDI. De intra-observer variabiliteit was slechts $5.2 \%$. We toonden aan dat het CAM een bruikbaar model is om de angiogene eigenschappen van endometriumweefsel te bestuderen. Onze methode maakt het mogelijk de angiogene reactie op een objectieve en reproduceerbare manier te bepalen.

In hoofdstuk 6 hebben we deze methode gebruikt om de angiogene eigenschappen te bepalen van endometriumweefsel verkregen in verschillende fases van de menstruele cyclus. Endometrium, onafhankelijk van de dag waarop weefsel is afgenomen, induceerde een significante stijging van de VDI in vergelijking tot de negatieve controles. De VDI's van de vroeg-proliferatieve, vroeg-secretoire en laat-secretoire fase waren significant hoger dan de VDI van de laat-proliferatieve fase. Hieruit volgt dat humaan endometrium angiogeen is gedurende de gehele cyclus en dat de mate van angiogenese bovendien een cyclische variatie vertoont. We veronderstellen dat verlenging van bestaande vaten tijdens de vroeg-proliferatieve fase en groei en draaiing van de spiraalarteriën tijdens de secretoire fase meer angiogene activiteit vergt dan uitgroei en handhaving van vaten tijdens de laat-proliferatieve fase.

In hoofdstuk 7 is de angiogene activiteit van peritoneumvloeistof van vrouwen met minimale tot milde endometriose bepaald. Vervolgens is de correlatie onderzocht van deze angiogene activiteit met de concentratie van enkele angiogene factoren alsmede met klinische variabelen, zoals fase van de menstruele cyclus, type laesie en rASRM classificatie. Van de onderzochte peritoneumvloeistofmonsters induceerde $85 \%$ angiogenese in het CAM. TNF- $\alpha$ en totaal eiwit correleerden significant met de 
VDI, terwijl IL-1 $\beta$, IL-8 en de klinische variabelen geen invloed hadden op de angiogene reactie. Deze studie bevestigt eerder aangetoonde angiogene activiteit van peritoneumvloeistof van vrouwen met endometriose en geeft bovendien een aanwijzing dat TNF- $\alpha$ hiervoor medeverantwoordelijk is.

In hoofdstuk 8 worden de resultaten van de studies bediscussieerd en worden voorstellen gedaan voor toekomstig onderzoek. We hebben aangetoond dat endometriumcellen tot invasie in staat zijn en angiogenese kunnen induceren. Bovendien bleek het mogelijk endometriose-achtige haarden in het CAM te laten ontwikkelen. Toekomstig onderzoek zou zich onder andere kunnen richten op de identificatie van genproducten die geassocieerd zijn met het invasieve gedrag. Omdat geïnvadeerde cellen voor verdere groei en ontwikkeling afhankelijk zijn van de vorming van nieuwe bloedvaten, zullen studies gericht op het remmen van angiogenese van belang zijn voor toekomstige therapeutische mogelijkheden. Voor behandelingsmogelijkheden, zoals gen- en immunotherapie, dienen specifieke endometriose- en/of endotheelcelmarkers geïdentificeerd te worden. 
Beurskens, M.PJ.C., Maas, J.W.M. en Evers, J.L.H. (1995) Subfertiliteit in Zuid-Limburg: berekening van incidentie en van beroep op specialistische zorg. Ned. Tijdschr. Geneesk., 139, 235-238.

Maas, J.W.M., Evers, J.L.H., ter Riet, G. and Kessels, A.G.H. (1997) Pregnancy rate following normal versus abnormal hysterosalpingography findings: a meta-analysis. Gynecol. Obstet. Invest., 43, 79-83.

Al-Inany, H.G., Dunselman, G.A.J., Dumoulin, J.C.M., Maas, J.W.M. and Evers, J.L.H. (1999) Fertility potential of individual sperm donors. Gynecol. Obstet. Invest., 47, 147-150.

Groothuis, P.G., Koks, C.A.M. en Maas, J.W.M. (1999) In-vitrostudies naar de vroege pathogenese van endometriose. Tijdschrift voor fertiliteitsonderzoek, 13, 51-55.

Maas, J.W.M., Le Noble, FA.C., Dunselman, G.A.J., de Goeij, A.F.P.M., StruijkerBoudier, H.A.J. and Evers, J.L.H. (1999) The chick embryo chorioallantoic membrane as a model to investigate the angiogenic properties of human endometrium. Gynecol. Obstet. Invest., 48, 108-112.

Maas, J.W.M. (2000) Verslag Stipendium Oranjekliniek: De rol van angiogenese bij het ontstaan van endometriose. Nederlands Tijdschrift voor Obstetrie \& Gynaecologie, $113,19-21$.

Maas, J.W.M., Calhaz-Jorge, C., ter Riet, G., Dunselman, G.A.J., de Goeij, A.F.P.M. and Sruijker-Boudier, H.A.J. (2001) Tumor necrosis factor- $\alpha$ but not interleukin-1 $\beta$ or interleukin- 8 concentrations correlate with angiogenic activity of peritoneal fluid from patients with minimal to mild endometriosis. Fertil. Steril., 75, 180-185.

Maas, J.W.M., Groothuis, P.G., Dunselman, G.A.J., de Goeij, A.F.P.M., StruijkerBoudier, H.A.J. and Evers, J.L.H. (2001) Development of endometriosis-like lesions after transplantation of human endometrial fragments onto the chick embryo chorioallantoic membrane. Hum. Reprod., 16, 627-631.

Maas, J.W.M., Groothuis, P.G., Dunselman, G.A.J., de Goeij, A.F.P.M., StruijkerBoudier, H.A.J. and Evers, J.L.H. (2001) Endometrial angiogenesis throughout the human menstrual cycle. Hum. Reprod., in press.

Maas, J.W.M., Groothuis, P.G., Dunselman, G.A.J., de Goeij, A.F.P.M., StruijkerBoudier, H.A.J. and Evers, J.L.H. (2001) Invasive potential of human endometrial cells in the chick embryo chorioallantoic membrane model. Submitted for publication. 
Notes
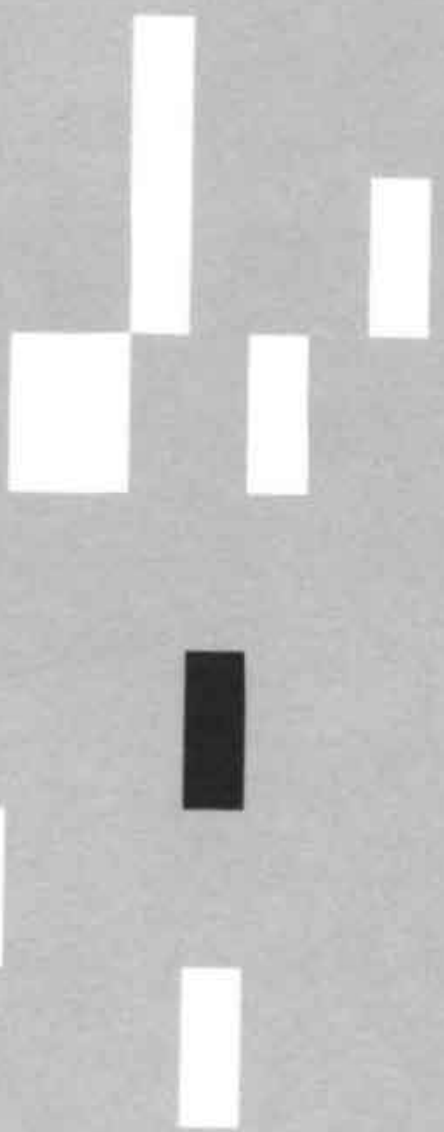



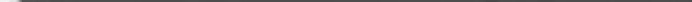


Endometriosis is a common gynecological disorder, characterized by the presence of endometrial tissue outside the uterine cavity. The signs and symptoms associated with endometriosis are dysmenorrhea, dyspareu: nia, chronic pelvic pain and impaired fertility. Although several theories exist regarding the pathogenesis of endometriosis, the transplantation theory is the most widely accepted. It presumes retrograde transportation of viable endometrial cells during menstruation, adhesion of these cells onto the peritoneum. invasion and subsequent rescue of the reproliferating tissue by angiogenesis from the host tissue. In this thesis the latter two phases, invasion and angiogenesis, were studied using the chick embryo chorioallantoic membrane (CAM) model.

The results of this study contribute to refining the transplantation theory. A model has been established which can be used to investigate the events that mimic the early pathogenesis of endometriosis, providing interesting opportunities for future studies. 